\title{
Development of Metal-Coated Ceramic Anodes \\ for Molten Carbonate Fuel Cells
}

$\mathrm{DOE} / \mathrm{MC} / 22194--3001$

Final Report

DE91 002082

\author{
A.C. Khandkar \\ S. Elangovan \\ L.G. Marianowski
}

Work Performed Under Contract No.: DE-AC21-85MC22194

\author{
For \\ U.S. Department of Energy \\ Office of Fossil Energy \\ Morgantown Energy Technology Center \\ P.O. Box 880 \\ Morgantown, West Virginia 26507-0880
}

By

Ceramatec, Inc.

2425 South 900 West

Salt Lake City, Utah 84119

March 1990 


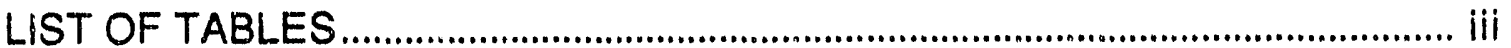

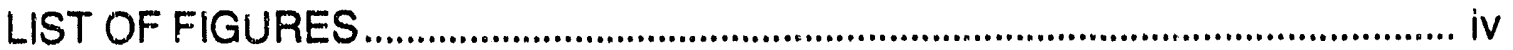

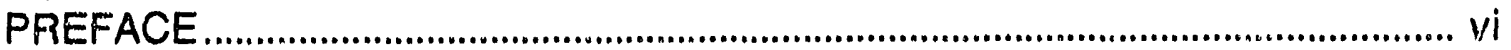

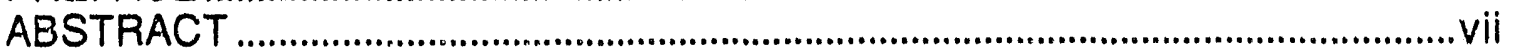

1.0 INTRODUCTION........................................................................................ 1

1.1 Anode Development................................................................................... 1

1.1.1 Original Program Plan .............................................................. 1

1.2 Summary of Progress During the First Year ............................................ 4

1.2.1 Modified Program Plan ................................................................ 8

2.0 TECHNICAL PROGRESS ..............................................................................114

2.1 Introduction................................................................................................ 14

2.2 Electroless Plating of $\mathrm{LiAlO}_{2}$ Powders..................................................14

2.3 Alternative Coating Methods...........................................................................16

2.3.1 Vacuum Sputter Technique .........................................................17

2.3.2 Chemical Vapor Deposition Technique ...................................17

2.4 Fabrication of Metal Coated gamma-LiAIO 2 Anodes..........................22

2.4.1 Sintering Trials ...............................................................................22

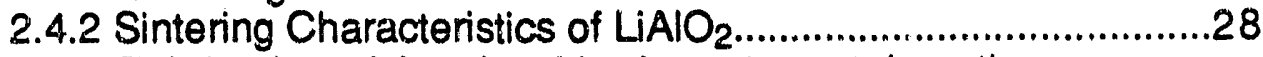

2.4.3 Fabrication of Anode with alternate metal coating

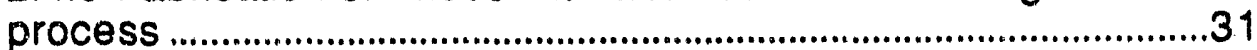

2.5 Tape Casting Trials........................................................................................32

$2.6 \mathrm{LiF} \mathrm{OO}_{2}$ Synthesis......................................................................................34

2.7 LiFeO2 Plating Trials...................................................................................34

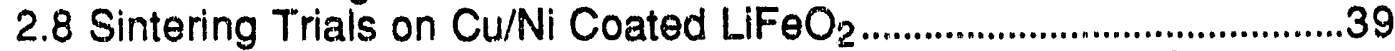

2.8.1 Fabrication Characteristics of Metal-coated $\mathrm{LiFeO}_{2}$

Powders....................................................................................................4 41

2.8.2 Synthesis of metal-coated $\mathrm{LFeO}_{2}$ tape cast anodes...........41

3.0 CREEP TESTING .....................................................................................44

3.1 Experimental Procedure ................................................................46

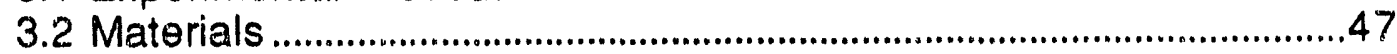

3.3 Resutls of Out-of-cell Creep Tests............................................................51

4.0 IN-CELL TESTING ..............................................................................56

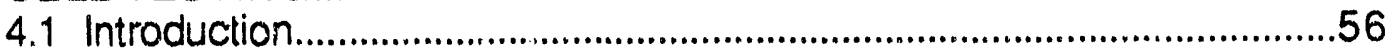

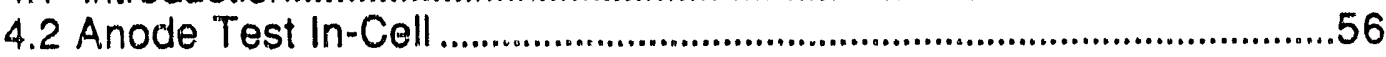

4.3 Conclusion .............................................................................................58

5.0 ANALYSIS OF POWDER COATING AND CREEP RESULTS ....................64

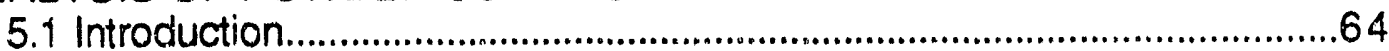

5.2 Metal Coating of High Surface Area Substrates.....................................64

5.3 Creep Behavior of Sintered Metal-coated Anodes.................................66

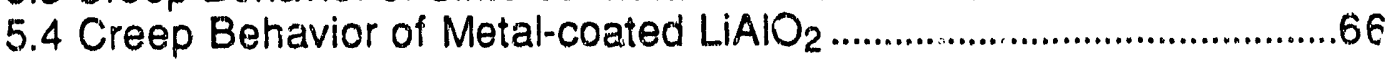


5.5 Creep Behavior of Metal-coated $\mathrm{LiFeO}_{2}$ Anodes

5.6 Summary

6.0 CONCLUSIONS AND RECOMMENDATIONS .74

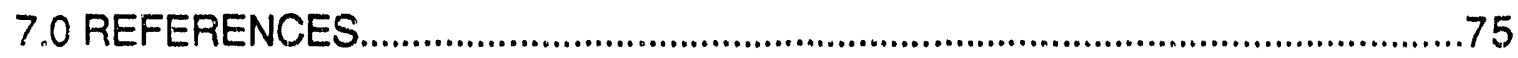

ACKNOWLEDGEMENTS

\section{APPENDICES}

A. Determination of Metal Loading.....................................................................77

B. Summary of Fabrication Trials of Metal Coated Anodes. 


\section{LIST OF TABLES}

Page

1. Organizational Responsibilities ............................................................ 3

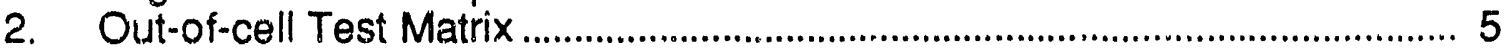

3. In-cell Test Matrix..................................................................................... 5

4. Metal Loading Of Electroless Plated $\mathrm{LIAIO}_{2}$ Batches ................................ 15

5. Metal coating characteristics of surface modified $\mathrm{LiAlO}_{2} \ldots \ldots \ldots \ldots \ldots \ldots \ldots \ldots \ldots . . . \ldots 16$

6. Summary of Plating Trials.......................................................................17

7. Bulk Density, Thickness and Porosity of Anode Coupons ..........................26

8. Bulk Density, Thickness and Porosity of Anode Coupons..........................26

9. Characterization of metal coated $\mathrm{LiAlO}_{2}$ powder - batch $\mathrm{LA41}$..................27

10. Characterization of metal coated $\mathrm{LiAlO}_{2}$ powder - batch $\mathrm{LA} 45 \ldots \ldots \ldots \ldots \ldots . . .27$

11. Metal Loading of Metal Coated LiFeO 2 Powder ..........................................39

12. Sintering Variations for Anode Fabrication Triais....................................40

13. Fabrication of Metal Coated $\mathrm{LiFeO}_{2}$ anodes ...............................................42

14. Summary of Creep Tesi Results ......................................................................52

15 Cell Test CERLiFe-1 Life Data ......................................................................59

16. Comparison of IR Loss, IR-Free, and Ploarization.................................61

17. Chemical Analysis.....................................................................................63

18. SEM/EDXS Microanalysis of CVD Ni Deposits on $\mathrm{LiAlO}_{2} \ldots \ldots \ldots \ldots \ldots \ldots \ldots \ldots 6$ 


\section{LIST OF FIGURES}

Page

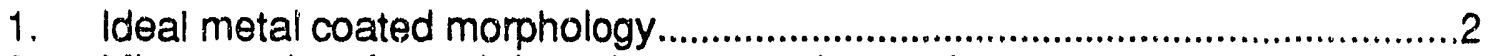

2. Micrographs of metal deposit on ceramic powder........................................

3. Electroless metal deposit on ceramic powder...............................................

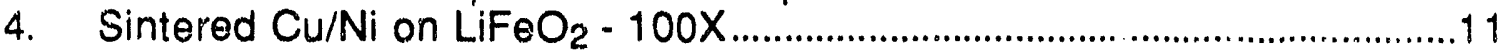

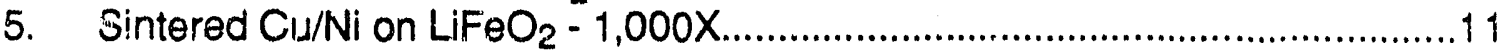

6. SEM of Hilmon powder (Hilmon-50) ...........................................................18

7. Polished Cross-section of Hilmon powder (Hilmon-50) ..............................19

8. Cross-sectional view of vacuum sputter coated powder (Batch GA

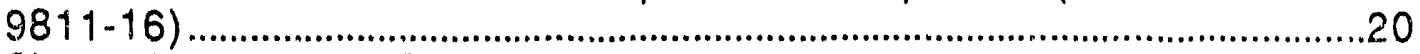

9. Sintered anode from GA 9811-17 powder....................................................21

10. Cross-sectional view of sintered anode from vacuum sputter coated powder (Batch GA-9811-25)........................................................................23

11. Cross-sectional view of post-creep tested anode from GA-9811-25 powder.

12. Lateral shrinking of metal coated $\mathrm{LiAlO}_{2}$ as a function of consolidation pressure

13. Porosity of metal coated $\mathrm{LIAIO}_{2}$ as a function of consolidation pressure.

14. Fracture strength of metal coated $\mathrm{LiAlO}_{2}$ as a function of consolidation pressure

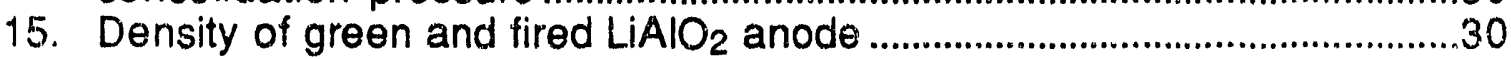

16. Density of green and fired $\mathrm{LiAlO}_{2}$ anode ....................................................

17. Effect of processing parameters on mean porosity .......................................33

18. Scatter in porosity values for gravity sintered anode from Hilmon powder...

19. Scatter in thickness values for gravity sintered anode from Hilmon powder

20. Scatter in porosity values for anode from Hilmon powder (sintered with consolidation pressure).

21. Scatter in thickness values for anode from Hilmon powder (sintered with consolidation pressure).

22. Scatter in porosity values for anode from electroless plated powder (sintered with consolidation pressure, $44.3 \%$ metal loading).

23. Scatter in thickness values for anode from electroless plated powder (sintered with consolidation pressure, $44.3 \%$ metal loading).......37

24. Scatter in porosity values for anode from electroless plated powder (sintered with consolidation pressure, $44.7 \%$ metal loading)

25. Scatter in thickness values for anode from electroless plated powder (sintered with consolidation pressure, $44.7 \%$ metal loading).......38

26. Effect of sintering temperature on the shrinkage of $\mathrm{LiFeO}_{2}$ anodes ..........43

27. Effect of sintering consolidation pressure on the shrinkage and porosity of $\mathrm{LiFeO}_{2}$ anodes

28. Creep test stand.

29. Block diagram of measuring system 


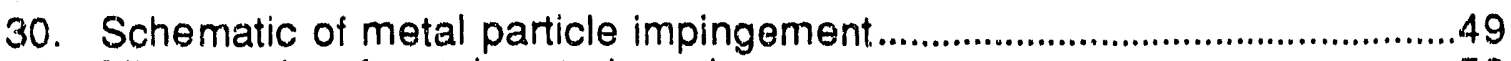

31. Micrographs of metal coated anodes.......................................................50

32. Creep test 2.3.1b-01 (electroless plated $\mathrm{LiAlO}_{2}$ ) ....................................53

33. Creep test 2.3.1b-02 (electroless plated LiAIO 2) .....................................53

34. Creep test 2.3.1b-03 (electroless plated $\mathrm{LIAlO}_{2}$ ) ......................................54

35. Creep test 2.3.1b-04 (electroless plated $\mathrm{LiAlO}_{2}$ ) ....................................54

36. Creep test 2.3.1b-14 (CVD LiAlO 2 - Hilmon 50) .........................................55

37. Creep test 2.3.1b-05 (electroless plated $\mathrm{LiFeO}_{2}$ ) ....................................55

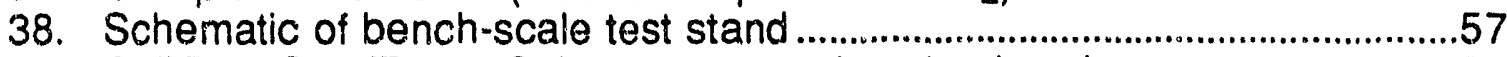

39 Cell Test CerLiFe-1 - Cell voltage at various load settings........................60

40. SOA Cell Test - Cell voltage at various load settings .................................62

41. Lithium Aluminate: Creep as a function of anode Porosity ..........................67

42. Lithium Aluminate: Creep as a function of metal Loading ............................68

43. Lithium Ferrite: Creep as a function of anode Porosity ................................71

44. Lithium Ferrite: Creep as a function of metal Loading ...............................72 


\section{PREFACE}

The main thrust of this program was to evaluate the long term stability and electrochemical performance of metal-coated ceramic anodes for use in molten carbonate fuel cells (MCFC) and to quantify and compare the cost and economics with the standard $\mathrm{Ni}(10 \% \mathrm{Cr})$ anode. Ceramatec was the prime contractor and was responsible for the overall conduct of the program. Ceramatec was also responsible for anode fabrication processes. IGT, the subcontractor, was responsible for anode creep testing and in-cell testing. 


\begin{abstract}
This report documents the developmental efforts on metal coating of various ceramic substrates $\left(\mathrm{LiAlO}_{2}, \mathrm{SrTiO}_{3}\right.$, and $\mathrm{LiFeO}$ ) and the critical issues associated with fabricating anodes using metal-coated $\mathrm{LiAlO}_{2}$ substrates. Electroless $\mathrm{Ni}$ and $\mathrm{Cu}$ coating technology was developed to achieve complete metal coverage on $\mathrm{LiAlO}_{2}$ powder substrates. The electroless metal plating process as previously developed by GE was found to result in non-uniform and incomplete metal coverage, especially on $\mathrm{LiAlO}_{2}$ substrates. Anodes fabricated from metal coated powders were found to have inadequate strength. The main problems related to the development of metal coated ceramic anodes were shown to be related to dewetting of the metal at elevated temperatures of anode fabrication. Metal coated $\mathrm{SrTiO}_{3}$ powders were fabricated into anodes by a process identical to that reported in the GE literature. Microstructural examination revealed that the grains of the ceramic had fused together, with the metal having dewetted from the surface of the ceramic. Alternate substrates that might allow for better wetting of the metal on the ceramic such as $\mathrm{LiFeO}_{2}$ and $\mathrm{Li}_{2} \mathrm{MnO}_{3}$ were identified. Cu/Ni-coated $(50: 50$ mol ratio, 50 w/o metal loading) $\mathrm{LiFeO}_{2}$ anodes were optimized to meet the MCFC anode specifications. Metalcoated gamma-LiAlO 2 substrates were also developed. Conventional electroless plating of $\mathrm{LiAlO}_{2}$ substrates was not successful due to hydrolysis of the substrate surface. However, by using suitable chemical surface modification methods, the gamma-LiAlO 2 substrate surface may be modified to allow a stable metal coated anode to be fabricated.

Creep testing of the metal coated ceramic anodes were conducted at IGT. From the creep results it was determined that the predominant creep mechanism is due to particle rearrangement. The anode porosity, and mean pore size had significant effect on the creep of the anode. Lower porosity and pore size consistent with performance criteria aro desired to reduce creep. Lower metal loading with uniformity of coverage will result in lower creep behavior of the anode. Of the two substrates evaluated, $\mathrm{LiFeO}_{2}$ in general exhibited lower creep which was attributed to superior metal adhesion.
\end{abstract}




\subsection{INTRODUCTION}

Previous studies[1] have shown that metal-coated ceramic anodes offer significant advantages over the current state-of-the-art $\mathrm{Ni}(10 \% \mathrm{Cr})$ anodes. The current anodes are $\sim 65 \%$ porous Ni plaques containing up to $10 \mathrm{w} / 0 \mathrm{Cr}$ to stabilize the anode against creep; the average pore size is 4-6 $\mu \mathrm{m}$. These anodes however undergo creep over an extended life in the MCFC which changes pore size distribution and morphology resulting in reduced surface area. These changes hence cause the electrochemical performance of the MCFC to degrade[2]. Another problem related to the $\mathrm{Cr}$-stabilized $\mathrm{Ni}$ anode is that during cell operation, the $\mathrm{Cr}$ undergoes corrosion to form $\mathrm{LiC}_{2} \mathrm{H}_{2}$ through reaction with the $\mathrm{Li}_{2} \mathrm{CO}_{3}-\mathrm{K}_{2} \mathrm{CO}_{3}(62-38 \mathrm{~mol}$ ratio) electrolyte[3]. The metalcoated ceramic substrate anodes are expected to offer substantial advantages over the current $\mathrm{Ni}(\mathrm{Cr})$ anodes. Conceptually, by utilizing a significant volume of a low cost ceramic substrate, problems related to sintering and morphological changes due to creep will be greatly reduced. Moreover, the absence of $\mathrm{Cr}$ as a stabilizer is expected to reduce corrosion/lithiation, thus allowing stable long term performance.

A critical requirement of such anodes is that the metal ( $\mathrm{Ni}$ or $\mathrm{Ni}-\mathrm{Cu}$ alloys) form a continuous film over the ceramic powder substrates thus allowing continuous electronic conduction paths. Figure 1 shows schematically the ideal metal coated ceramic anode morphology. The thin metal layer on the ceramic particles is expecteo to show substantially increased creep resistance. Further advantages of this approach are that anode morphology can be better controlled by controlling the size of the ceramic (substrate) powder and the metal coating thickness. In addition, substantial cosi reductions are also expected by using reduced amounts of metal and low cost ceramic substrates. The advantages have been demonstrated in experimental research programs conducted at General Electric[4].

The current program was undertaken to extend the GE work and develop, fabricate and evaluate the long term stability and elecirochemical performance of metal-coated ceramic anodes, and to compare the cost/economics with the current standard $\mathrm{Ni}(\mathrm{Cr})$ anodes. Ceramatec is the prime contractor and is responsible for the overall conduct of the program. Ceramatec is also responsible for powder preparation, electrode fabrication, electrode characterization and economic assessments. IGT, the subcoritractor, is responsible for in-cell and out-of-cell testing and analysis of performance, endurance, sintering, and creep behavior of the porous electrodes. The responsibilities of each organization are shown in Table 1.

\subsection{Anode Development}

\subsubsection{Original Program Plan}

Based on the available literature[1,2,5,6], Ceramatec and IGT proposed testing of four different metal-coated ceramic anodes. The detaiis were given in 


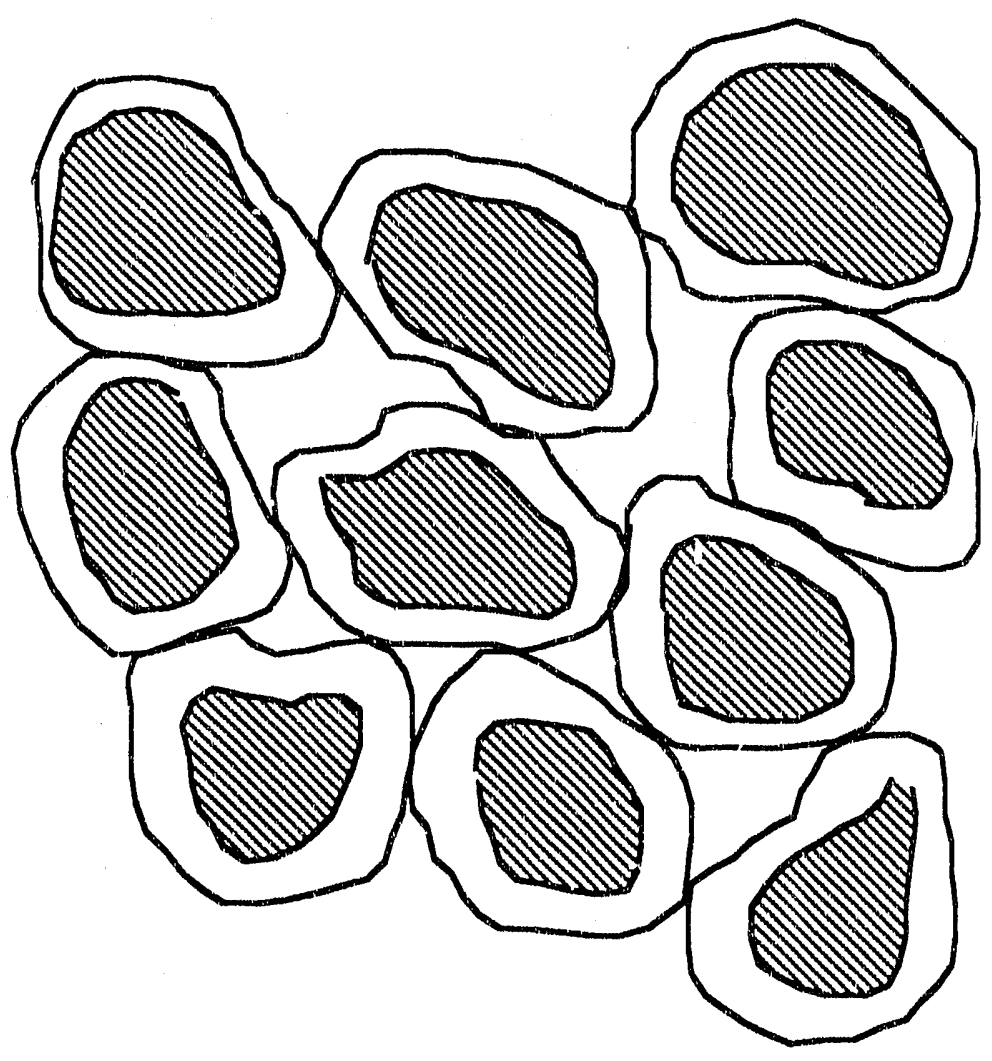

Figure 1. Ideal metal coated morphology 
Table 1. Organizational Responsibilities

Task 1. Write and Submit Management Plan....................... Ceramatec/IGT

Task 2. Develop, Fabricate, and Test Flat and

Ribbed Metal-Coated Ceramic Anodes

Task 2.1 Develop and Submit Anode Development Goals Document .............................................. IGT

Task 2.2 Write and Submit Task 2.3 Test Plan............ IGT/Ceramatec

Task 2.3 Develop, Fabricate, and Test Anodes

$\begin{array}{ll}\text { Task 2.3.1 } & \text { Test Anodes Out-of-Cell } \\ \text { Task 2.3.1a } & \text { Fabricate Anodes.................................. Ceramatec } \\ \text { Task 2.3.1b } & \text { Test Anodes Out-of-Cell ..................... IGT } \\ \text { Task 2.3.2 Test Anodes In-Cell } & \\ \text { Task 2.3.2a } & \text { Fabricate Anodes...................................... Ceramatec } \\ \text { Task 2.3.2b } & \text { Test Anodes In-Cell........................ IGT } \\ \text { Task 2.3.3 Analyze Anodes Post-Test................. IGT }\end{array}$

Task 3. Characterize Anodes at Expected Range of Fuel Cell Conditions

Task 3.1 Write and Submit Task 3.2 Test Plan............ Ceramatec/IGT

Task 3.2 Fabricate Anodes............................................ Ceramatec

Task 3.2.1 Fabricate Anodes................................. Ceramatec

Task 3.2.2 Test Anodes Out-of-Cell ...................... IGT

Task 3.2.3 Test Anodes In-Cell............................ IGT

Task 3.2.4 Analyze Anodes Post-Test................. IGT

Task 4. Fabricate and Submit Samples ............................... Ceramatec

Task 5. Evaluate Anode Cost .................................................. Ceramatec 
the Task 2.3 Test Plan[7]. The main thrust of the program was to coat by electroless deposition techniques $\mathrm{Cu} / \mathrm{Ni}$ alloys $(50 \mathrm{Ni} / 50 \mathrm{Cu} ; 30 \mathrm{Ni} / 70 \mathrm{Cu}$ and $100 \mathrm{Cu}$ ) on gamma-LiAlO 2 and $50 \mathrm{Ni} / 50 \mathrm{Cu}$ cn a conductive ceramic substrate. Each of the above compositions were to be characterized for coating uniformity and completeness, and fabricated into $45 \%$ and $60 \%$ porous anodes via a tape casting approach, thus yielding eight compusition/porosity combinations. These eight anodes were to be tested for creep resistance in out-of-cell tests (Subtask 2.3.1b) at five different pressure/temperature conditions. Each of these eight anodes were to be also tested in in-cell tests in duplicate to evaluate electrochemical stability (Subtask 2.3.2b). Tables 2 and 3 show the out-of-cell test matrix and in-cell test matrix, respectively. Based on the posi-test evaluations (Subtask 2.3.3), metal/ceramic anodes were to be fabricated using high volume processing technology for continued long term stáuility testing under Task 3.0. Of the compositions to be tested, four anode samples (selected by the COTR) were to be fabricat3d and delivered to the COTR under Task 4.0. Finally, the cost parameters associated with large scale manufacture of the metal/coated ceramic anodes were to be evaluated, and the costs compared to the standard $\mathrm{Ni}(\mathrm{Cr})$ anodes under Task 5.0.

\subsection{Summary of Progress During the First Year}

The major developmental concerns related to fabrication of metal-coated ceramic anodes were:

- Very little information was available in the literature on $\mathrm{Ni}$ or $\mathrm{Cu}$ coating of powder substrates, especially regarding film coverage, adhesion and wettability.

- The substrate, gamma-LiAlO stability considerations in the MCFC environment, was susceptible to hydrolysis and posed a severe problem in the aqueous electroless plating baths.

- Wetting of the $\mathrm{Ni}$ and $\mathrm{Cu}$ on $\mathrm{LiAlO}_{2}$ substrates was poor, especially at the operating temperature and $\mathrm{PO}_{2}$ conditions of MCFC anodes.

\section{Wetting Angle Studies}

A matrix of experiments was conducted to study wetting characteristics of $\mathrm{Ni}, \mathrm{Cu}$ and $50 \mathrm{w} / 0 \mathrm{Ni} / \mathrm{Cu}$ alloys on sintered $\mathrm{Al}_{2} \mathrm{O}_{3}$ and gamma-LiAlO substrates. The parameters investigated were surface treatment, surface roughness, time and temperature of firing, and atmosphere. Wetting angles were determined as function of temperature and atmospheie. The results indicated that in the case of prefired flat ceramic substrates, $\mathrm{Ni}$ and $\mathrm{Cu}$ exhibited lower wetting angles (better adhesion) on roughened surfaces. Pretreatments such as chemical etching with $\mathrm{NaOH}$ or $\mathrm{HF}$ or sensitization and activation of surfaces improved wetting characteristics. These results however did not have parity with SEM observations on metal-coated powder substrates. This is due to the surface tortuosity and lack of adequate controi over the dispersion 
Table 2. Out-of-cell Test Matrix

\begin{tabular}{|c|c|c|c|c|c|c|c|}
\hline $\begin{array}{c}\text { Metal } \\
\text { m\% W\% }\end{array}$ & Ceramic & $\begin{array}{c}\text { Porosity } \\
\%\end{array}$ & $\begin{array}{c}25 \text { psi } \\
650^{\circ} \mathrm{C}\end{array}$ & $\begin{array}{c}50 \mathrm{psi} \\
600^{\circ} \mathrm{C}\end{array}$ & $\begin{array}{c}50 \mathrm{psi} \\
650^{\circ} \mathrm{C}\end{array}$ & $\begin{array}{c}50 \mathrm{psi} \\
700^{\circ} \mathrm{C}\end{array}$ & $\begin{array}{c}100 \mathrm{psi} \\
650^{\circ} \mathrm{C}\end{array}$ \\
\hline $50 \mathrm{Ni} / 50 \mathrm{Cu}$ & $\mathrm{LiAlO}_{2}$ & 45 & $\mathrm{X}$ & $\mathrm{X}$ & $\mathrm{X}$ & $\mathrm{X}$ & $\mathrm{X}$ \\
\hline $50 \mathrm{Ni} / 50 \mathrm{Cu}$ & $\mathrm{LiAlO}_{2}$ & 60 & $\mathrm{X}$ & $\mathrm{X}$ & $\mathrm{X}$ & $\mathrm{X}$ & $\mathrm{X}$ \\
\hline $30 \mathrm{Ni} / 70 \mathrm{Cu}$ & $\mathrm{LiAlO}_{2}$ & 45 & $\mathrm{X}$ & $\mathrm{X}$ & $\mathrm{X}$ & $\mathrm{X}$ & $\mathrm{X}$ \\
\hline $30 \mathrm{Ni} / 70 \mathrm{Cu}$ & $\mathrm{LiAlO}_{2}$ & 60 & $\mathrm{X}$ & $\mathrm{X}$ & $\mathrm{X}$ & $\mathrm{X}$ & $\mathrm{X}$ \\
\hline $100 \mathrm{Cu}$ & LiAlO & 45 & $\mathrm{X}$ & $\mathrm{X}$ & $\mathrm{X}$ & $\mathrm{X}$ & $\mathrm{X}$ \\
\hline $50 \mathrm{Ni} / 50 \mathrm{Cu}$ & $\begin{array}{c}\text { Coiductive } \\
\text { Ceramic }\end{array}$ & 45 & $\mathrm{X}$ & $\mathrm{X}$ & $\mathrm{X}$ & $\mathrm{X}$ & $\mathrm{X}$ \\
\hline $50 \mathrm{Ni} / 50 \mathrm{Cu}$ & $\begin{array}{c}\text { Conductive } \\
\text { Ceramic }\end{array}$ & 60 & $\mathrm{X}$ & $\mathrm{X}$ & $\mathrm{X}$ & $\mathrm{X}$ & $\mathrm{X}$ \\
\hline
\end{tabular}

Table 3. In-cell Test Matrix

\begin{tabular}{|c|c|c|c|c|c|}
\hline No. & $\begin{array}{c}\text { Metal } \\
\text { Wt\% } / \mathrm{Wt}_{4}\end{array}$ & Ceramic & Porosity & Test I & $\begin{array}{c}\text { Duplicate } \\
\text { Test II }\end{array}$ \\
\hline 1 & $50 \mathrm{Ni} / 50 \mathrm{Cu}$ & $\mathrm{LiAlO}_{2}$ & 45 & $\mathrm{X}$ & $\mathrm{X}$ \\
\hline 2 & $50 \mathrm{Ni} / 50 \mathrm{Cu}$ & $\mathrm{LiAlO}_{2}$ & 60 & $\mathrm{X}$ & $\mathrm{X}$ \\
\hline 3 & $30 \mathrm{Ni} / 70 \mathrm{Cu}$ & $\mathrm{LiAlO}_{2}$ & 45 & $\mathrm{X}$ & $\mathrm{X}$ \\
\hline 4 & $30 \mathrm{Ni} / 70 \mathrm{Cu}$ & $\mathrm{LiAlO}_{2}$ & 60 & $\mathrm{X}$ & $\mathrm{X}$ \\
\hline 5 & $100 \mathrm{Cu}$ & $\mathrm{LiAlO}_{2}$ & 45 & $\mathrm{X}$ & $\mathrm{X}$ \\
\hline 6 & $100 \mathrm{Cu}$ & $\mathrm{LiAlO}_{2}$ & 60 & $\mathrm{X}$ & $\mathrm{X}$ \\
\hline 7 & $50 \mathrm{Ni} / 50 \mathrm{Cu}$ & $\begin{array}{c}\text { Conductive } \\
\text { Ceramic }\end{array}$ & 45 & $\mathrm{X}$ & $\mathrm{X}$ \\
\hline 8 & $50 \mathrm{Ni} / 50 \mathrm{Cu}$ & $\begin{array}{c}\text { Conductive } \\
\text { Ceramic }\end{array}$ & 60 & $\mathrm{X}$ & $\mathrm{X}$ \\
\hline
\end{tabular}


characteristics of these powders, especially $\mathrm{LiAlO}_{2}$ powders. It is well known that for optimal dispersion of powders in liquids, $\mathrm{pH}$ control plays a major role. For $\mathrm{Al}_{2} \mathrm{O}_{3}$ powders, it has been determined that alkaline $\mathrm{pH}$ provide the best condition for dispersion. Similar information is not available for $\mathrm{LIAlO}_{2}$. However, $\mathrm{LiAlO}_{2}$ powders hydrolyze according to the following equation:

$$
4 \mathrm{LiAlO}_{2}+12 \mathrm{H}_{2} \mathrm{O} \ldots-. .>\mathrm{Li}_{2} \mathrm{O} \cdot 2 \mathrm{Al}_{2} \mathrm{O}_{3} \cdot 11 \mathrm{H}_{2} \mathrm{O}+2 \mathrm{LiOH}
$$

This reaction raises the $\mathrm{pH}$ of the liquid and equilibrium $\mathrm{pH}$ is typically in the range of 10-11. The electroless plating baths used had a pH of 4 , and were ineffective at the alkaline $\mathrm{pH}$ ranges. (Alkaline baths such as Ni-P baths were found to result in poor coating quality and moreover did not yield conductive anodes. Development of an alternate alkaline electroless coating chemistry was well beyond the scope of this project*).

In order to achieve the desired porosity of $45.60 \%$ for the metal coated anodes at the specified metal loading levels of $50 \%$, it was necessary to start with ceramic powders of about 10 to 15 microns. SEM examination of the Lithco $\mathrm{LiAlO}_{2}$ powders revealed that the particles were very irregular in shape and consisted of hard porous agglomerates of much smaller particles. These powders presented special difficulty in achieving complete coating. Ceramatec then developed a spray dried $\mathrm{LiAlO}_{2}$ powder which had larger and more uniform agglomerates and was easier to coat with metal.

Initial metal coating trials followed the approach developed by GE [4] of sensitization, activation and electroless plating of the gamma-LiAlO 2 ceramic particles. This approach in general resulted in incomplete metal film coverage. The problems were essentiaily related to hydrolysis of the $\mathrm{LiAlO}_{2}$ substrates. Electroless plating process consists of three sequential steps, sensitization and activation of the surface and catalytic deposition of the metal at the activated sites. Hydrolysis results in surface dissolution resulting in a partial loss of the activated surface, thus exposing the unactivated surface onto which autocatalytic reduction of the metal ions does not occur. This causes non uniformity in coating. After considerable experimeritation, a method involving addition of a soluble $\mathrm{Li}$ ion salt compatible with the chemistry of the electroless plating bath was developed. This method was found to work well for $\mathrm{Cu}$ baths, but $\mathrm{Ni}$ baths were found to either have extremely low deposition rates or shut down the autocatalytic activity completely. An alternative approach involved soaking the as-received or sized ceramic powder in a solution of a copper or nickel salt, followed by decomposition of the salt to the oxide and subsequent reduction of the residue to the metal. The metal coverage was uniform but incomplete as shown in Figure 2. In a modified approach, this salt batch was fired on the surface of the powder which was dispersed using ultrasonic agitation to break up sotter agglomerates as well as to disperse the particles

\footnotetext{
- Manulacturers of electroless plating solutions such as Allied Kelite were cortacted for assistance from their R\&D labs. Several discussions were held but no work was performed directly due to the difficult nature of the requests.
} 

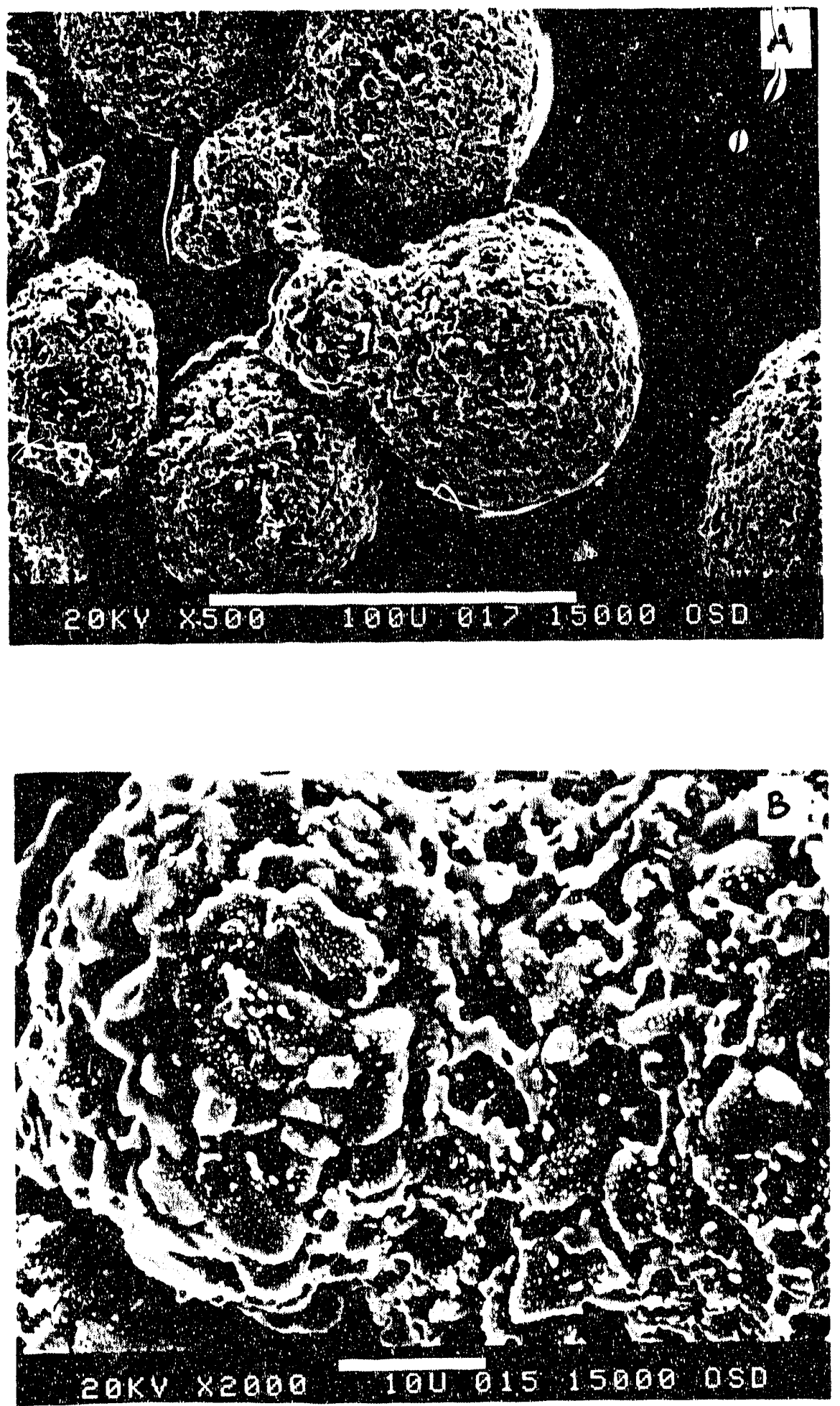

Figure 2. Micrographs of metal deposit on ceramic powder (adsorption - decomposition method) 
and expose the surfaces. After firing, the powcer, with a metal oxide layer was directly electroless plated without sensitization and activation. This resulted in uniform metal deposition with nearly complete coverage of the particle surface for both $\mathrm{Al}_{2} \mathrm{O}_{3}$ and $\mathrm{LiAlO}_{2}$ powder substrates. SEM of particles coated by this method are shown in Figure 3 ( $a$ and b). The inner pores, however, have a thinner coat and exhibit incomplete coverage $(3 \mathrm{c})$.

If .ras clear from the results of the wetting angle study that in reducing atmospheres the metal films dewet from the surface This problem is exacerbated with the higher surface area powders and thus necessitated a sintering procedure which allowed good strength to be obtained at the lowest sintering temperature. At these sintering temperatures $\left(<1100^{\circ} \mathrm{C}\right)$ only the metal is expected to sinter together. Hence the mechanical properties of the sintered body such as strength and creep resistance are critically dependent on the strength of the metal-metal bonds and the metal-ceramic adhesion.

The sintering procedure used was similar to that mentioned in the literature $[4,5]$. For the coated powder substrates evaluated, it was determined that at low metal loadings ( $\sim 25 w t . \%)$ higher sintering temperatures gave better strengths. For higher metal loadings, ( $50 w t \%)$, lower sintering temperatures gave acceptable anode plaques. In all cases, greater dewetting was observed at the higher sintering temperatures. In all cases compaction of the metal coated powders at moderate pressures gave stronger sintered bodies. Electrical conductivity of the anodes correlated well with anode strength. This is not surprising since the strength in these porous metal coated ceramic anodes is derived from the presence of sufficient metal bonds in three dimensions, a factnr which also contributes to high conductivity.

From the above results it was concluded that the difficulty in obtaining sintered anode plaques with acceptable mechanical properties was due partly to poor coating uniformity as well as poor wetting and adhesion characteristics. Thus the program plan was modified to explore other options under Task 2.3.1c, which would lead to the development of metal-coated ceramic anodes.

\subsubsection{Modified Program Plan}

A major program modification was made in order to develop stable metal-coated ceramic anodes. This was necessary because of urianticipated experimental difficulties in reproducing the plating results obtained at GE in their prior program. Specifically, $u$ hile the GE reports mentioned plating efforts on $\mathrm{LiAlO}_{2}$ substrates, problems associated with hydrolysis of the substrates as well as wetting of the metals on the substrates were not mentioned. Specific subtasks in the modified program plan included:

1) Selection and evaluation of alternate ceramic powders

2) Plating process development for gamma-LiAlO 2 , and

3) Evaluation of alternate metal deposition techniques. 

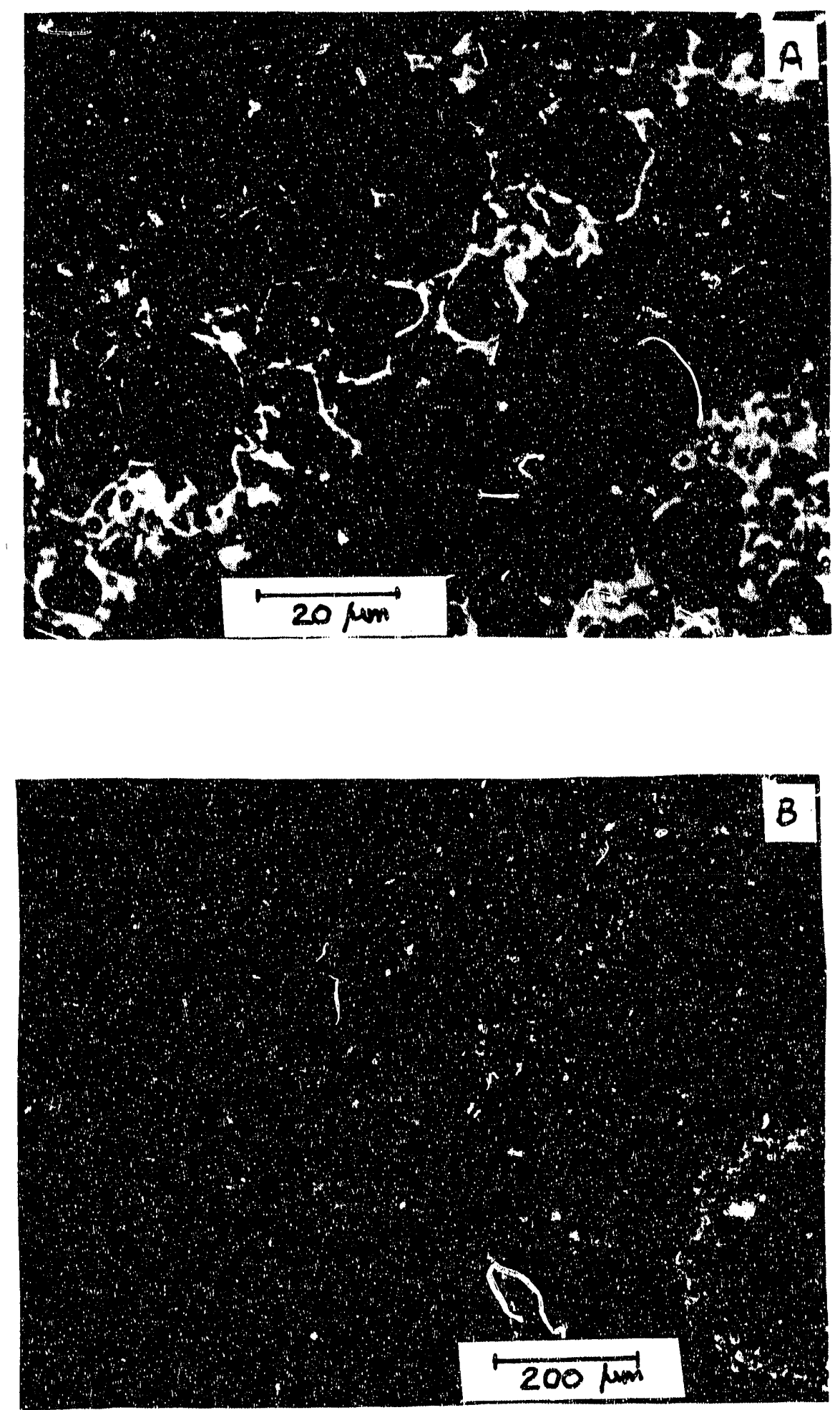

Figure 3. Electroless metal deposit on ceramic powder (improved activation process) 
Work Plan

Subtask 1.0: Selection of Alternate Ceramic Powders Substrates

Experimental data from the initial part of the program indicate that both plating and sintering of the anodes are strongly inilisenced by the surface energy interactions of the metal and ceramic. For metals such as $\mathrm{Ni}$ and $\mathrm{Cu}$ on gamma-LiAlO 2 substrates, the surface energies are such that the contact angle during nucleation and wetting is very large. This results in nucleation of discrete spheres of the metal during plating that must grow until they are in contact with each other before a continuous coating results. With conventional electroless plating of gamma-LiAlO spaced to result in a smooth, thin coating. During sintering, the large equilibrium contact angle results in congealing of the as-plated spheres into larger spheres, resulting in decreased metal coverage. The objective of subtask i was to compare the nucleation and wetting cinaracteristics of other candidate ceramics with gamma-L $\mathrm{IAlO}_{2}$ in an effori to locate an alternate composition with a more favorable surface energy interaction with $\mathrm{Cu}$ and $\mathrm{Ni}$. Specifically, a low contact angle is desired. Alternate materials that were selected for evaluation included $\mathrm{SrTiO}_{3}, \mathrm{LiFeO}_{2}, \mathrm{Li}_{2} \mathrm{MnO}_{3}$ and $\mathrm{Li}_{2} \mathrm{SnO}_{3}$. Of these, the latter three ceramic compositions were determined to be stable in moiten carbonate environment [8]. L.iFeO $\mathrm{F}_{2}$ was selected as the first substrate for evaluation.

A large batch of $\mathrm{LiFeO}_{2}$ was synthesized. The powder was determined to be phase pure using $X R D$, and the particie size distribution and BET surface area were characterized. The powder was milied to get a mean particle size centered around $15 \mu \mathrm{m}$. The metal wetting characteristics were found to be favorable as compared to $\mathrm{LiAlO}_{2}$. Electroless $\mathrm{Ni}$ and $\mathrm{Cu}$ plating process was developed and the optimal conditions were determined. The metal coating appeared to be uniform as determined by SEM/EDXS. In a separate study the phase stability of $\mathrm{LiFeO}_{2}$, in a molten carbonate melt, was determined. Anodes were fabricated from $\mathrm{LiFeO}_{2}$ particles with $\mathrm{Ni}$, $\mathrm{Cu}$ or $\mathrm{Ni} / \mathrm{Cu}$ alloys. The sintered anodes exhibited good mechanical properties. SEM examination of the microstructure revealed good coating of the particles with well formed necks thus confirming the observed strength of sintered anodes. Typical microstructures are shown in Figures 4 and 5. After several fabrication trials, it was determined that moderate pressure during sintering improved the strength of the porous anode plaques. The porosity of the sintered plaques was varied by varying the compaction pressure. Since the results from metal coating and wetting behavior on $\mathrm{LiFeO}_{2}$ powoier substrates were encouraging, further evaluation on alternate substrates was discontinued. Plating and anode fabrication trials on $\mathrm{urTiO}_{3}$ were carried out in order to try and reproduce previous results obtained[4]. Wetting studies on $\mathrm{SrTiO}_{3}$ substrate, however, indicated that both $\mathrm{Ni}$ and $\mathrm{Cu}$ dewetted significantly and thus the evaluation was not pursued iurther. 


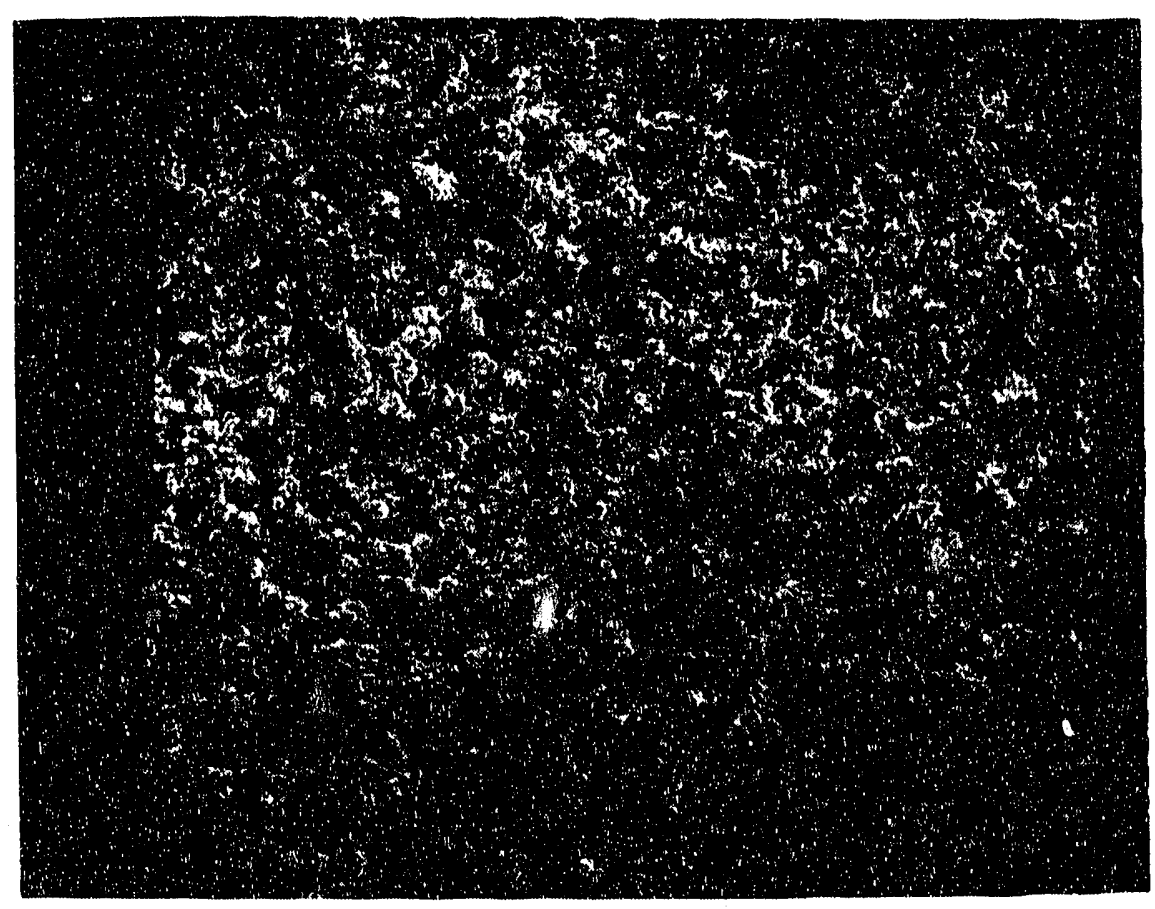

Figure 4. Sintered $\mathrm{Cu} / \mathrm{Ni}$ on $\mathrm{LiFeO}_{2}-100 \mathrm{X}$

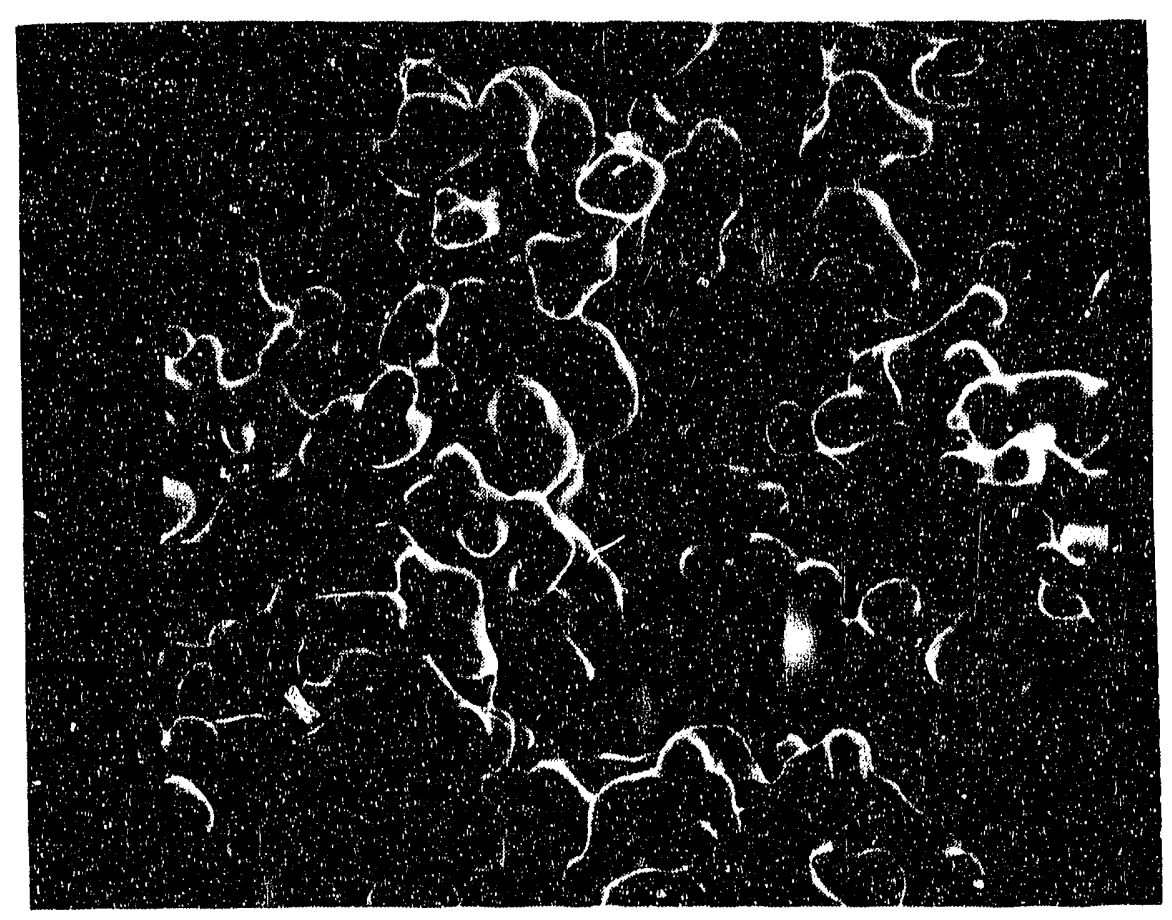

Figure 5. Sintered $\mathrm{Cu} / \mathrm{Ni}$ on $\mathrm{LiFeO} 2-1,000 \mathrm{X}$ 
Three approaches were planned in this subtask in an effort to achieve a uniform, well bonded metal coating on gamma- $\mathrm{LiAlO}_{2}$ : (1) chemically modify the surface of the $\mathrm{LiAlO}_{2}$ to change the surface energy and achieve a low contact angle with $\mathrm{Cu}, \mathrm{Ni}$ and $\mathrm{Ni} / \mathrm{Cu},(2)$ apply a thin polymer layer to gamma$\mathrm{LiAlO}_{2}$ which will protect the gamma-LiAlO from hydrolysis and which is selected for its ease of uniform electroless plating, and (3) apply the metal coating by a "dry" technique such as chemical vapor deposition which avoids the hydrolysis problem and which may result in greater uniformity of nucleation in a thin coating. The following specific efforts were planned for subtask 2.0.

(1) Chemical Surface Modification of $L i A l Q_{2}:-$ There are three primary methods used to achieve a good bond between metals and ceramics; namely, reaction bonding, flux bonding and frit bonding. In reaction bonded metal films, a thin oxide coating such as $\mathrm{CuO}$ is added. This oxide reacts with the ceramic substrate to form a ternary (or quaternary oxide) layer which promotes adhesion of the metal. This method has been tried earlier where the alternative activation procedure was found to give better coating. In flux bonding, a low melting oxide which forms a eutectic (such as $\mathrm{Bi}_{2} \mathrm{O}_{3}$ used for metallizing $\mathrm{Al}_{2} \mathrm{O}_{3}$ substrates) is used. Above the firing tempizature, the eutectic melts and wets the substrate and the metal and thereby promotes adhesive bonding. In the third method, about 2 - 10 wt $\%$ glass frit is added to the metal. The mechanism is similar to the flux bonding mechanism, where the wetting behavior is exploited to form a good bond. While these techniques are commonly used in metallizing ceramics for electronics applications [9], no technique has been developed for use on powder substrates. The use of active metals such as Ti or Mo-Mn brazes was expiored. The challenge was to obtain a uniform precoat of the active metal and to retain it during the coating process. Of the different techniques attempted, the physical vapor deposition technique lent itself to the easiest technique of coating a prelayer. Lack of time prevented further investigation of this approach. The electroless plating processes investigated showed mixed results and no clear recommenoation could be made. Several process variations of the electroless plating method were investigated. The best results on powder dispersion were obtained using controlled ultrasonic agitation. Wetting agents to promote surface contact between the plating bath and powder substrates were found to inhibit filtration, and in any case, did not improve the coating quality to any appreciable degree. The plating rates were varied using different bath concentrations and powder loadings and ternperatures.

(2) Polymer Interlayer:- $\mathrm{Ni}$ and $\mathrm{Cu}$ are routinely electroless plated on plastics. Based on a review of the literature, a polymer layer compatible with electroless plating and one that could be uniformly deposited on the ceramic particles was to be evaluated. The aim would be to passivate gamma-LiAlO 2 powder with a thin continuous "barrier" layer of the polymer and electroless plate this surface with $\mathrm{Ni}$ and $\mathrm{Cu}$. This was attempted but was found to be experimentally difficult to assess the quality of the barrier layer. Hence further attempts were discontinued. 
(3) Vapor Deposition - Chemical vapor deposition (CVD) has the potential to produce very fine nuclei and result in a continuous, smooth, thin metal coating. Much progress has occurred in the past 10 years on fluidized bed CVD of small particle size distributions. A subcontract was initiated with GA Technologies, a leader in CVD technology for the nuclear industry. GA was to attempt conventional fluidized bed CVD to coat $\mathrm{Ni}$ using the carbonyl process. A second subcontract was initiated with Synterials, who attempted to barrel coat $\mathrm{Ni}$ in a hir h temperature CVD process. This latter CVD process had the advantage of being very low cost compared to conventional CVD. In addition, vacuum sputter deposition of a metal alloy was also considered due to its greater "throwing power", whereby the metal deposit would adhere better. A subcontract was issued to Hilmon Associates who attempted fluidized bed sputtering of $\mathrm{LiAlO}_{2}$ powder using a metal alloy target.

\section{Subtask 3.0: Alternate Metal Deposition Techniques}

This subtask continued with efforts at applying $\mathrm{Cu}$ or Ni by decomposition of metal saits or organometallic salts deposited from solution on the ceramic powder. The objective was to produce a uniform coating at a lower cost than electroless plating. Emphasis was on the use of $\mathrm{Cu}$ or $\mathrm{Ni}$ acetate in an alcohul solution to avoid the hydrolysis of gamma- $\mathrm{LiAlO}_{2}$ that would occur if a water solution was used.

The impact of the additional work performed under Task 2.3.1c, conducted over approximately 5 months, represented an increase in the time required for anode development as originally planned. To accommodate this extra effort, the number of out- of-cell tests and in-cell tests planned originally to be conducted at IGT was reduced. While Ceramatec worked on Task 2.3.1c, IGT worked to refine their creep test apparatus and procedure. In the next section, the technical progress on the modified work plan (Task 2.3.1c) is detailed. 


\subsection{TECHNICAL PROGRESS}

\subsection{Intreduation}

The focus of this this program was to (a) develop a method of metal coating high surface area substrates and (b) to fabricate and test anodes made from such metal-coated ceramic substrates and demonstrate better creep characteristics, lower cost, as well as acceptable in-cell performance.

The major technical effort in the first year of this two year program was devoted to the development of electroless Ni plating technology for high surface area substrates such as $\mathrm{LiAlO}_{2}$. Developing this technology posed a technical challenge due to several factors such as substrate reactivity with the electroless plating baths, poor quality control of the metal deposition because of inadequate control over particle dispersion, and finally and perhaps most importantly, poor wetting of the metal on the ceramic leading to poor adhesion of the metal film. The problems have been documented in great detail and a summary is presented in the previous section.

\subsection{Electroless Plating of LiAlO2_ Powders}

Initial work on metal plating was done on relatively coarse (15-25 micron size, LA. 100 Ceramatec gamma-LiAlO 2 ) powders and electroless plating of these powders to the desired metal loading was achieved. By contrast, plating of high surface area $\mathrm{LiAlO}_{2}$ powder from Foote Mineral Co. was found to be nonuniform. Examination of each powder batch under the optical stereo microscope indicated that a greater proportion of the high surface area powder was poorly coated. This may be due to the greater tendency of the finer particles to agglomerate together in solution.

Prior results suggested that metal-coated $\mathrm{LiAlO}_{2}$ powders of $10-15 \mathrm{um}$ particle size did not yield sintered anodes of the desired pore size distribution. The next batch of powder investigated had a mean particle size of 6-7 microns. It also had the desired equiaxed particle shape which will allow for more uniform particle packing. Herice, the main thrust of Ceramatec's efforts was to develop metal plating processes for this low surface area powder compatible to achieving uniform and complete metal coverage at the desired metal loading. Initial efforts to repeat the process defined in the GE report [1] did not result in complete coverage. The process was then modified to allow for monitoring of the $\mathrm{pH}$ of the wash water to get consistency of washing of the sensitized and activated powders. Further, the activated powder was dispersed in the reducing agent in order to break up agglomerates by gentle mechanical agitation before adding the treated powder into the plating bath. Ultrasonic agitation at this stage was found to be detrimental to the final plating quality. This modified process resulted in a significant improvement in plating quality as evidenced by metallographic techniques. Table 4 gives the metal loading as determined by a combination of the redox titration technique (to determine the Cu content) and 
Table 4. Metal Loading Of Electroless Plated $\mathrm{LIAlO}_{2}$ Batches

\begin{tabular}{|c|c|c|c|}
\hline Batch No. & $\begin{array}{c}\text { Metal } \\
\text { Fraction }\end{array}$ & $\% \mathrm{Cu}$ & $\% \mathrm{Ni}$ \\
\hline LA-20 & 49.83 & 24.62 & 25.21 \\
\hline LA-21 & 44.70 & 24.86 & 19.84 \\
\hline LA-23 & 51.94 & 35.14 & 16.80 \\
\hline LA-24 & 49.13 & 30.60 & 18.35 \\
\hline LA-26 & 51.16 & 27.25 & 23.91 \\
\hline LA-27 & 47.10 & 26.42 & 20.68 \\
\hline LA-33 & 46.26 & 23.93 & 22.33 \\
\hline LA-32 & 53.66 & 26.02 & 27.64 \\
\hline
\end{tabular}

the acid etch technique ( to determine the total metal fraction). Appendix A dfscribes the procedure employed for determination of metal loading of powders.

\section{Alternate Electroless Plating Process:}

Initial work on plating the $\mathrm{LiAlO}_{2}$ powders was done by sensitizing the powder with $\mathrm{SnCl}_{2}$ followed by activation with a $\mathrm{Pd}$ or $\mathrm{Ag}$ catalyst. This procedure, however, was slightly modified to improve the metal coverage on the ceramic and reduce the costs involved with using the Pd or Ag catalyst. The alternate method involved soaking of the $\mathrm{LiAlO}_{2}$ powder in a copper or nickel salt followed by decomposition of the salt and reduction of the resultins oxide to the metal. This approach was expected to produce a much finer aild uniform deposition of the metal which could be a base for electroless plating. Several nickel and copper salts were tried, and nickel hydroxide and copper sulfate gave the best results. After reduction these powders were electrolessly plated with copper and nickel. The results on the metal loading of these powders are shown in Table 5.

\section{Wetting Studies:}

Since severe dewetting of the Ni/Cu alloy on the ceramic was occurring at sintering temperatures, several experiments were conducted to improve wetting behavior. Reactive metals such as titanium and several oxides of the fourth period elements such as Iron, Chromium, Titanium, Vanadium, Manganese, and Yttrium were identified as potential candidates to improve wetting.

Titanium in the form of $\mathrm{TiH}_{2}$ was initially used. The $\mathrm{TiH}_{2}$ was ball milled to a small size of approximately $1 \mu \mathrm{m}$ and mixed with the $\mathrm{LiAlO}_{2}$ powders in varying concentrations. After being plated with $\mathrm{Ni} / \mathrm{Cu}$, these powders were taken to sintering temperatures and examined. Nickel-cobalt and nickel-iron 
Table 5. Metal Coating Characteristics of Surface Modified $\mathrm{LiAlO}_{2}$

\begin{tabular}{|c|c|c|c|c|}
\hline Batch No. & $\begin{array}{c}\text { Metal Salt } \\
\text { Used }\end{array}$ & $\begin{array}{c}\text { Metal } \\
\text { Fraction }\end{array}$ & $\% \mathrm{Cr}$ & $\% \mathrm{Ni}$ \\
\hline $\mathrm{LA}-39$ & $\left.\mathrm{Ni}_{1}, \mathrm{OH}\right)_{2}$ & 44.74 & - & - \\
\hline $\mathrm{LA}-40$ & $\mathrm{CuSO}_{4}$ & 33.90 & 22.29 & 11.61 \\
\hline $\mathrm{LA}-41$ & $\mathrm{Ni}(\mathrm{OH})_{2}$ & 44.32 & 23.29 & 21.03 \\
\hline $\mathrm{LA}-42$ & $\mathrm{CuSO}_{4}$ & 5.99 & 27.29 & 8.20 \\
\hline $\mathrm{LA}-43$ & $\mathrm{CuSO} 4$ & 41.38 & 33.32 & 8.06 \\
\hline $\mathrm{LA}-44$ & $\mathrm{Ni}(\mathrm{OH})_{2}$ & 46.03 & 26.73 & 12.30 \\
\hline $\mathrm{LA}-45$ & $\mathrm{Ni}(\mathrm{OH})_{2}$ & 48.18 & 27.13 & 21.05 \\
\hline $\mathrm{LA}-46$ & $\mathrm{Ni}(\mathrm{OH})_{2}$ & 51.07 & 23.84 & 27.23 \\
\hline $\mathrm{LA}-47$ & $\mathrm{Ni}(\mathrm{OH})_{2}$ & 47.89 & 25.10 & 22.79 \\
\hline
\end{tabular}

plating baths were also developed and plated onto the $\mathrm{LiAlO}_{2}$ substrate. This was followed by making anode plaques by normal procedures and firing the plaque in a typical sintering cycle. The resulting plated anodes were then examined by SEM.

The anode electrolessly plated with $\mathrm{Fe} / \mathrm{Cu} / \mathrm{Ni}$ showed a significant amount of metal necks that had formed i $n$ the $\mathrm{LiAlO}_{2}$ surface and between the particles suggesting a more favorable wetting situation. Further, the anode plaques sintered from this batch of powder were stronger and more conductive than in previous attempts without the addition of iron. The EDS spectrum of these anodes showed that approximately equal amounts of iron, nickel and copper are present.

The anode electrolessly plated with $\mathrm{Co} / \mathrm{Cu} / \mathrm{Ni}$ showed a similar dewetting situation to that of a Cu/Ni anode without the addition of cobalt. Thi suggested that cobalt has little, if any, effect on the wetting situation.

Five batches each of about $100 \mathrm{gms}$ of $\mathrm{LiAlO}_{2}$ (low surface area, Foote Mineral Co., gamma phase) electrolessly coated to $\sim 50 \mathrm{w} / 0$ metal loading. There appeared to be a large variation in the metal loading. The results of the metal loading determinations are listed in Table 6. The metal-loading was determined by the acid etch technique.

\subsection{Alternative Coating Methods}

Trials with electroless plating of ceramic substrate showed that the metal coverage typically was incomplete. To obtain better metal coverage, alternate coating techniques were evaluated. The two processes that appeared promising were vacuum sputter (VS) technique and chemical vapor deposition (CVD) technique. Hilmon Laboratories and GA Technologies were chosen to evaluate the two metal coating techniques. Hilmon Laboratories used a high rate vacuum sputter deposition technique coupled with a proprietary particle handling method to deposit the metal onto the $\mathrm{LiAlO}_{2}$ powder which allows for 
Table 6. Summary of Plating Trials

\begin{tabular}{|c|c|c|}
\hline Batch No. & Substrate & $\begin{array}{l}\text { Metal Loading } \\
(\mathrm{w} / \mathrm{0})\end{array}$ \\
\hline 1 & $\mathrm{LIAIO}_{2}$ & 63.0 \\
\hline$\overline{2}$ & $\mathrm{LIAlO}_{2}$ & 60.0 \\
\hline 3 & $\mathrm{LIAIO}_{2}$ & 46.1 \\
\hline 4 & $\mathrm{LiAlO}_{2}$ & 47.79 \\
\hline 5 & $\mathrm{LIAIO}_{2}$ & 65.84 \\
\hline$\overline{6}$ & $\mathrm{LIAlO}_{2}$ & $4 \sqrt[15]{4}$ \\
\hline
\end{tabular}

uniform and complete metal deposition. The CVD process employed by GA Technologies involved coating of nickei carbonyl to the $\mathrm{LiAlO}_{2}$ substrate in a fluidized bed reactor to obtain a shiny nickel coat. The results of metal coatings trials from these techniques are discussed below.

\subsubsection{Vacuum Sputter TGchnique}

The two initial samples of the metal coated $\mathrm{LiAlO}_{2}$ powder from the Hilmon Laboratories had metal loadings of $19.84 \%(6.10 \% \mathrm{Cu}$ and $13.74 \% \mathrm{Ni})$ and $34.04 \%(10.92 \% \mathrm{Cu}$ and $23.12 \% \mathrm{Ni})$ instead of the desired loadings of $25 \%$ and $50 \%$, respectively. The discrepancy in metal loading was traced to the basis of calculation done at Hilinon laboratories. They based their calculations on initial product instead of the final weight, which resulted in a lower metal loading than anticipated.

The next Hilmon batch was run to get 50 weight percent with approximately $3 \%$ to $4 \% \mathrm{Cr}$ with the following results. The metal loading for the Hilmon powder identified as Hilmon 602 was $49.43 \% \mathrm{Ni}$ and $\mathrm{Cu}$ with about $5 \%$ $\mathrm{Cr}$ metal. Micrographs of the Hilmon powder are shown in Figure 6 . Figure 7 shows cross sectional micrographs of Hilmon powder and the metal coverage appears to be fairly evenly distributed over the particles.

\subsubsection{Chemical Vapor Depesition Technique}

Based on nickel carbonyl chemical vapor deposition thermochemistry, GA Technologies determined that a 3 hour run in the coating reactor would be necessary to obtain $50 \%$ metal loading. The initial two runs yielded powders identified as GA 981116 and GA 981117 with metal loadings of $12.26 \%$ and $17.58 \% \mathrm{Ni}$, respectively. The cross-sectional micrographs in Figure 8 show that the metal distribution over the ceramic particle is essentially uniform and continuous; however, when taken to typical firing temperatures, serious dewetting occurred as is shown in Figure 9. 

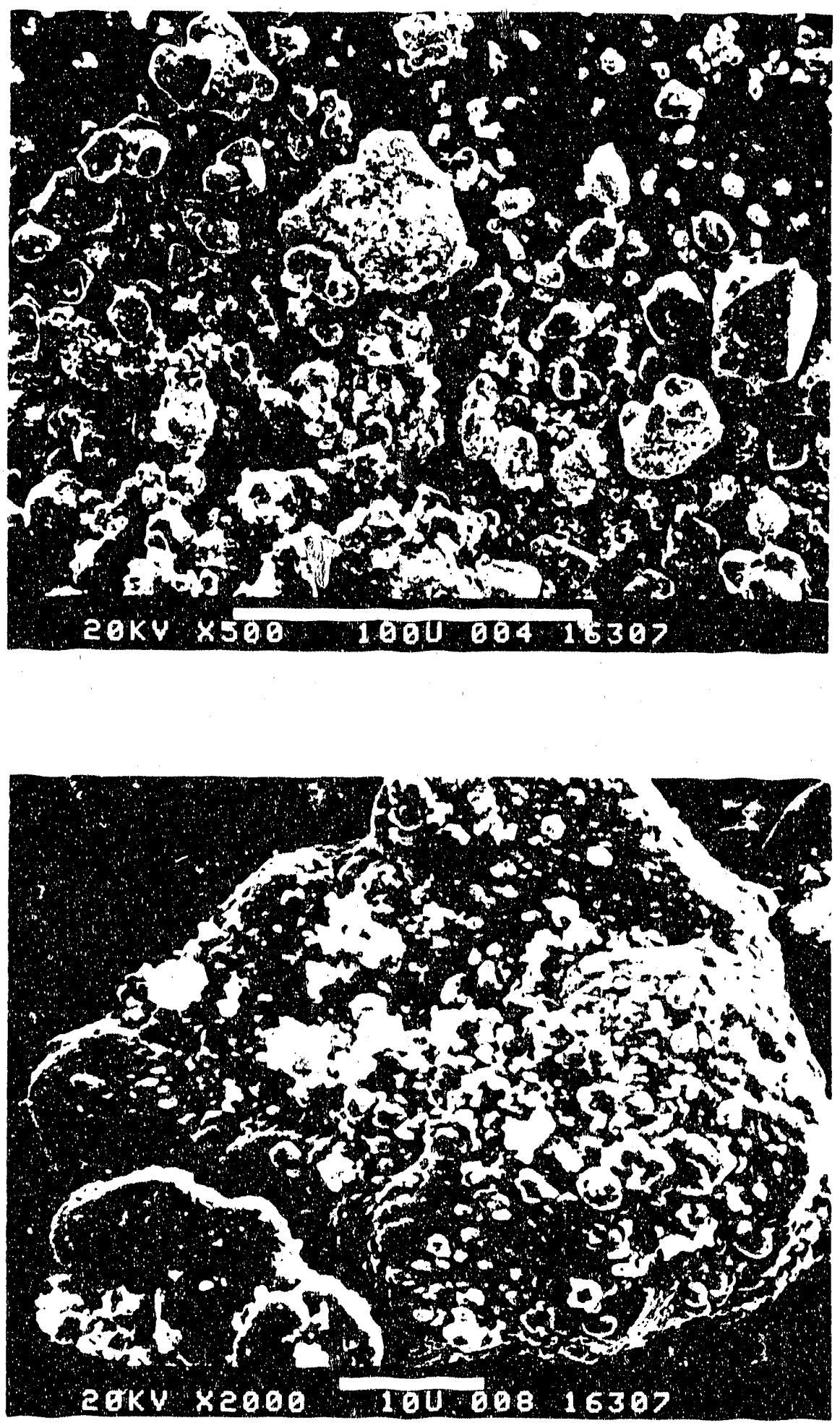

Figure 6. SEM of Hilmon Powder (Hilmon-50) 

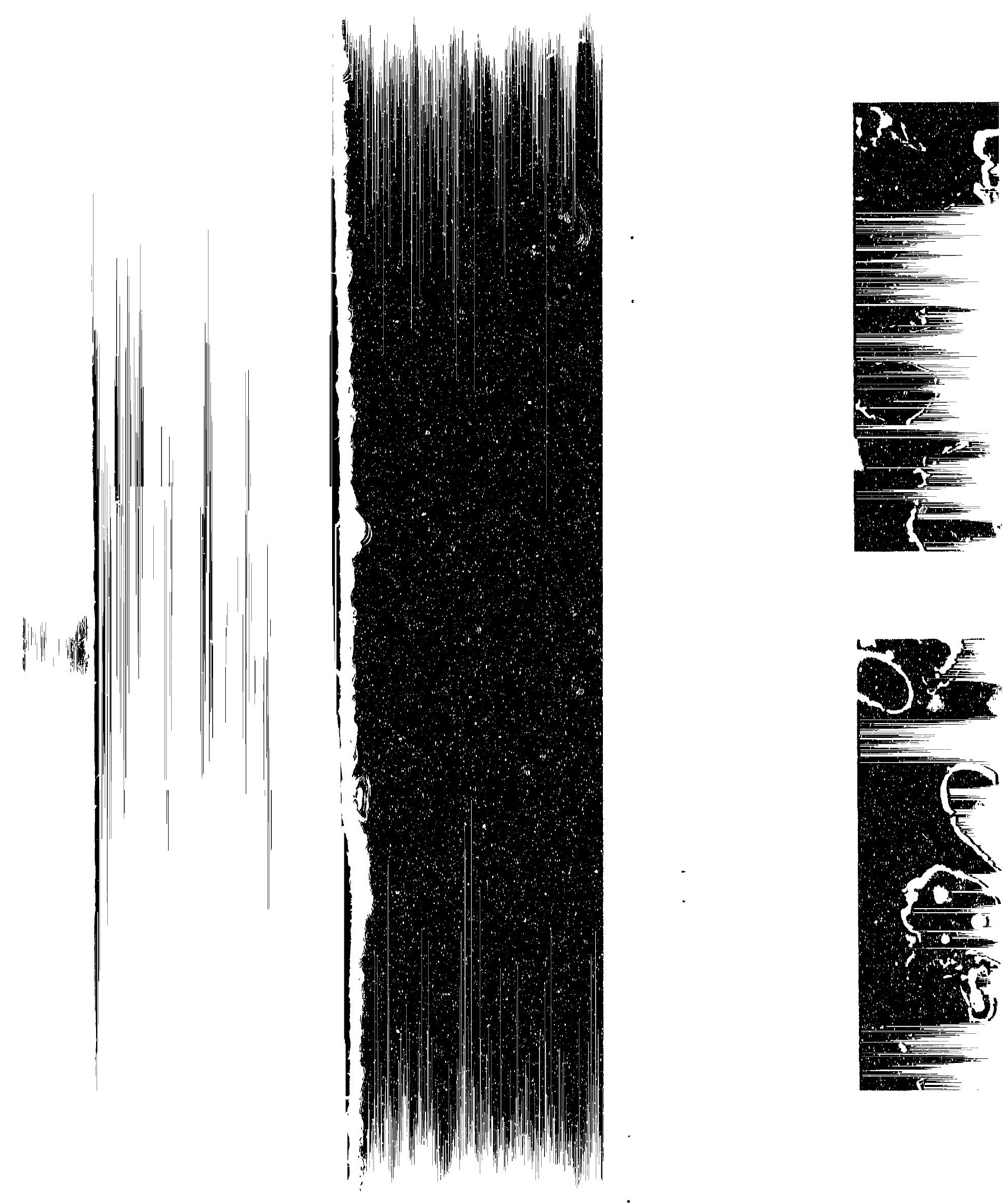

Figure 7 . Polish 

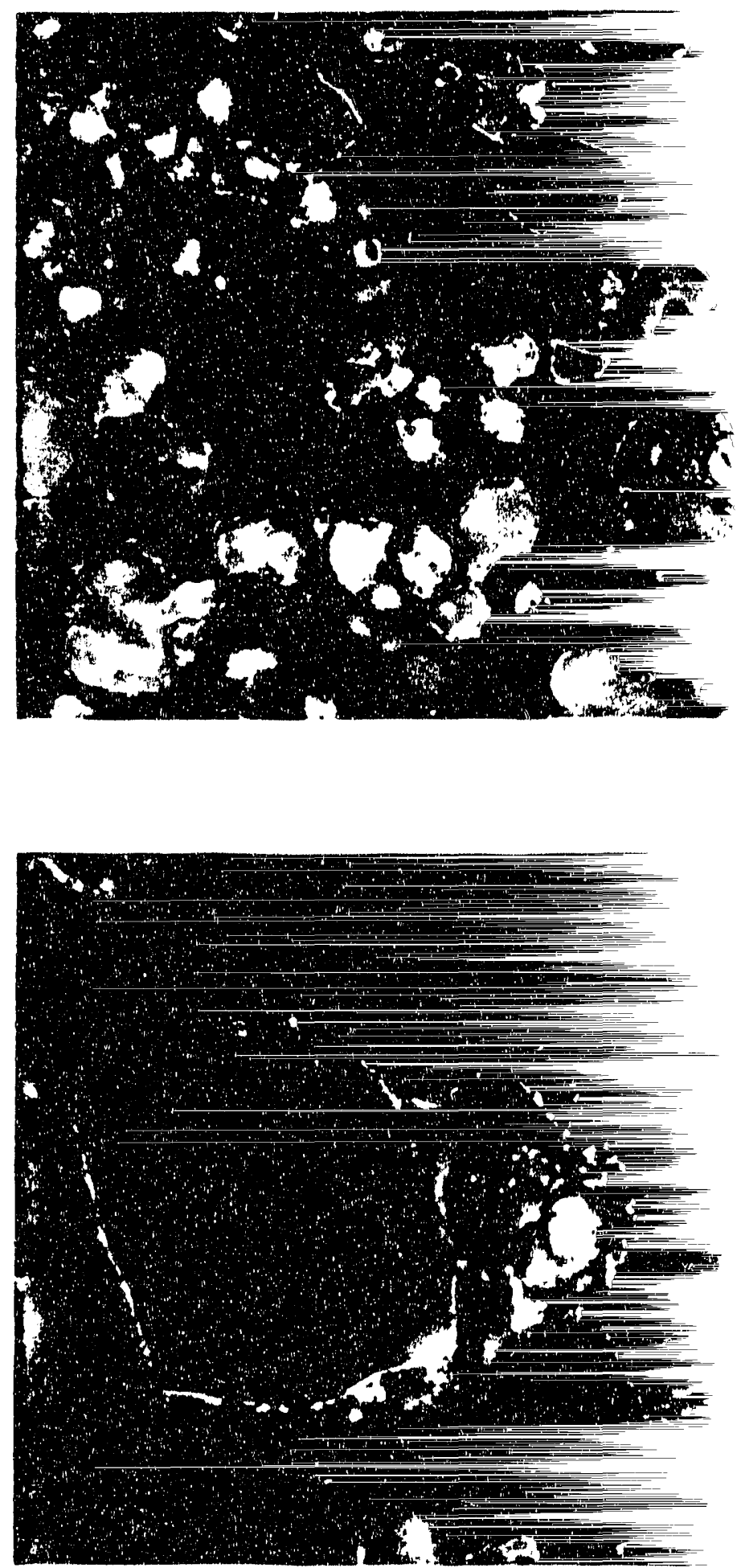

Figure 8. Cross-sectional view of Vacuum Sputter (Batch GA 9811-16)

Magnification: a) $500 \mathrm{X}$, b) $1000 \mathrm{X}$ 

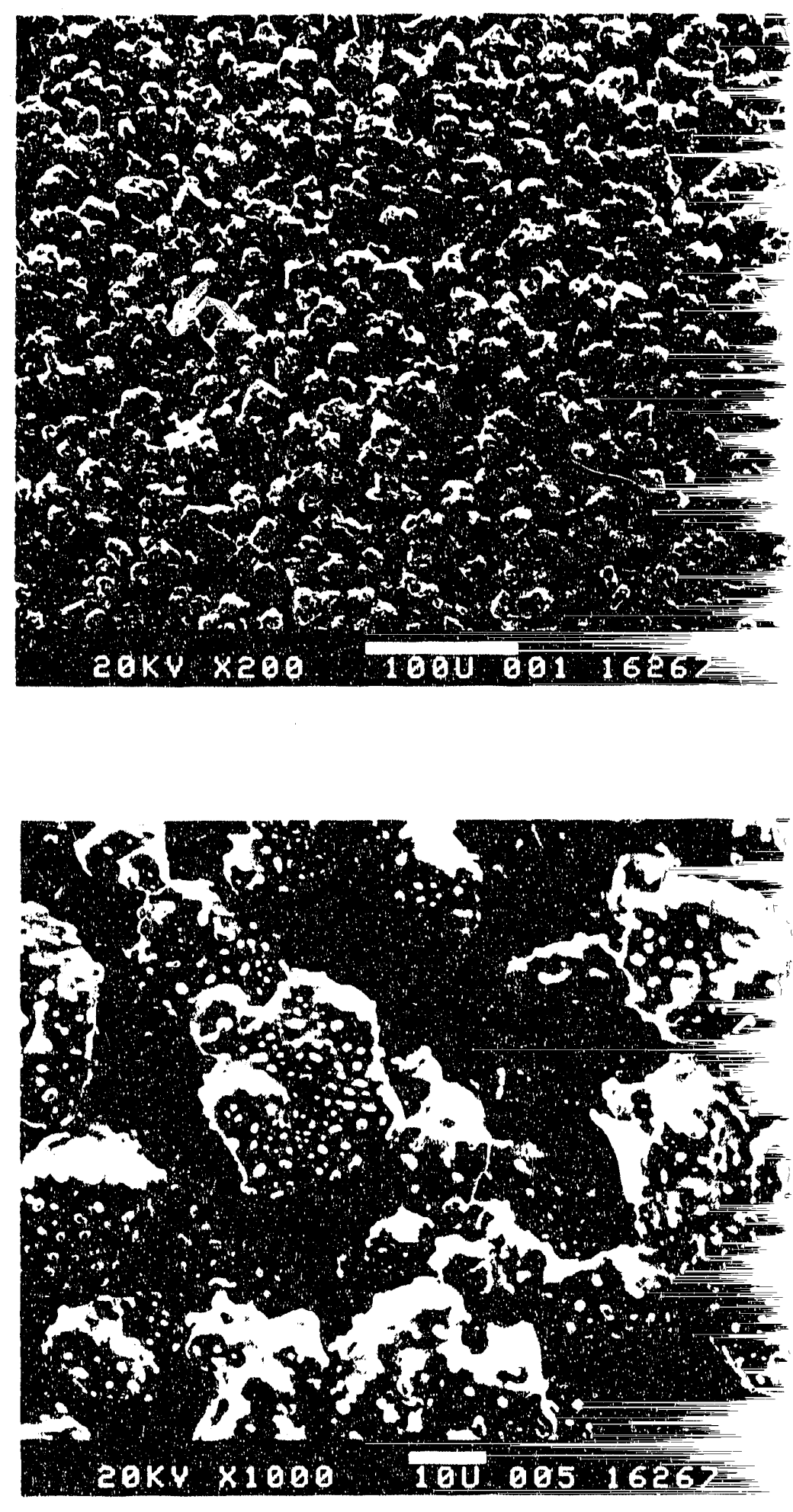

Figure 9 . Sintered anode from GA 9811-17 Pow 
It was determined that the lower metal loading from a three hour run was due to an unoptimized system and the loss of fines resulting in reduced bed volume. In an effort to avoid these problems, two alternate approaches were evaluated. With the first option, the $\mathrm{LiAlO}_{2}$ powder batches were to receive two separate coatings by the CVD process. However, after the first coat, the powder was oxidized in the atmosphere before receiving the second coat of metal. The second option that would avoid the $\mathrm{NiO}_{x}$ "interlayer" would be to coat the powder for a longer time (about 6 to 8 hours). After obtaining a certain coating thickness on the powder, the nickel began to nucleate on itself and the final product contained discrete nickel particles that were unassociated with ceramic particles.

After consideration of the problems and advantages involved, the first option was chosen and GA 981125 was produced. The metal loading of this batch was determined to be $51.35 \%$ nickel. The cross sectional micrographs of sintered anodes (Figure 10) show the metal coverage is more complete and uniform. The metal completely wets the ceramic material as shown in the cross sections of a post-creep tested sample in Figure 11.

Discussions were also initiated with INCO in order to establish the economic feasibility of CVD metal-cuating of ceramic powder substrates due to the completeness and uniformity of metal-coating observed on CVD coated powders. A batch of about 500 grams of $\mathrm{LiAlO}_{2}$ powder (LSA, Foote Mineral Co.) was sent to Novamet, a subsidiary of INCO which specializes in specialty coating requirements. Novamet has two processes, a fluidized bed reactor similar to the type used by GA for CVD coating of $\mathrm{LiAlO}_{2}$ and a proprietary process for coating small particle size powders. The preliminary indications seemed that the costs of conducting plating trials would be substantially lower compared to the costs incurred earlier at GA. Further, the economics of the process was expected to be similar to that for the INCO 287 CVD Ni powder, which is used by MCFC developers for anode fabrication. The first baich of coating by Novamet resulted in a metal loading of $10.1 \%$. Due to lack of time, further trials to achieve higher metal loading were not attempted.

\subsection{Fabrication of Metal Coated gamma-LiAlO2 Anedes}

\subsubsection{Sintering Trials}

Gravity Sintering Technique:

Anode fabrication was initially carried out by the gravity sintering method without using any consolidation pressure. The anode characteristics formed due to gravity settling alone is expected to mimic anode fabrication morphology via a tape casting procedure. Further, it was determined that the bulk density of gravity settled metal-coated powder was within $10 \%$ of the bulk density obtained after sintering. This data was encouraging because it allowed for a tape casting approach to be a viable one for fabricating larger anodes. The gravity sintering process was optimized by conducting several trials to 

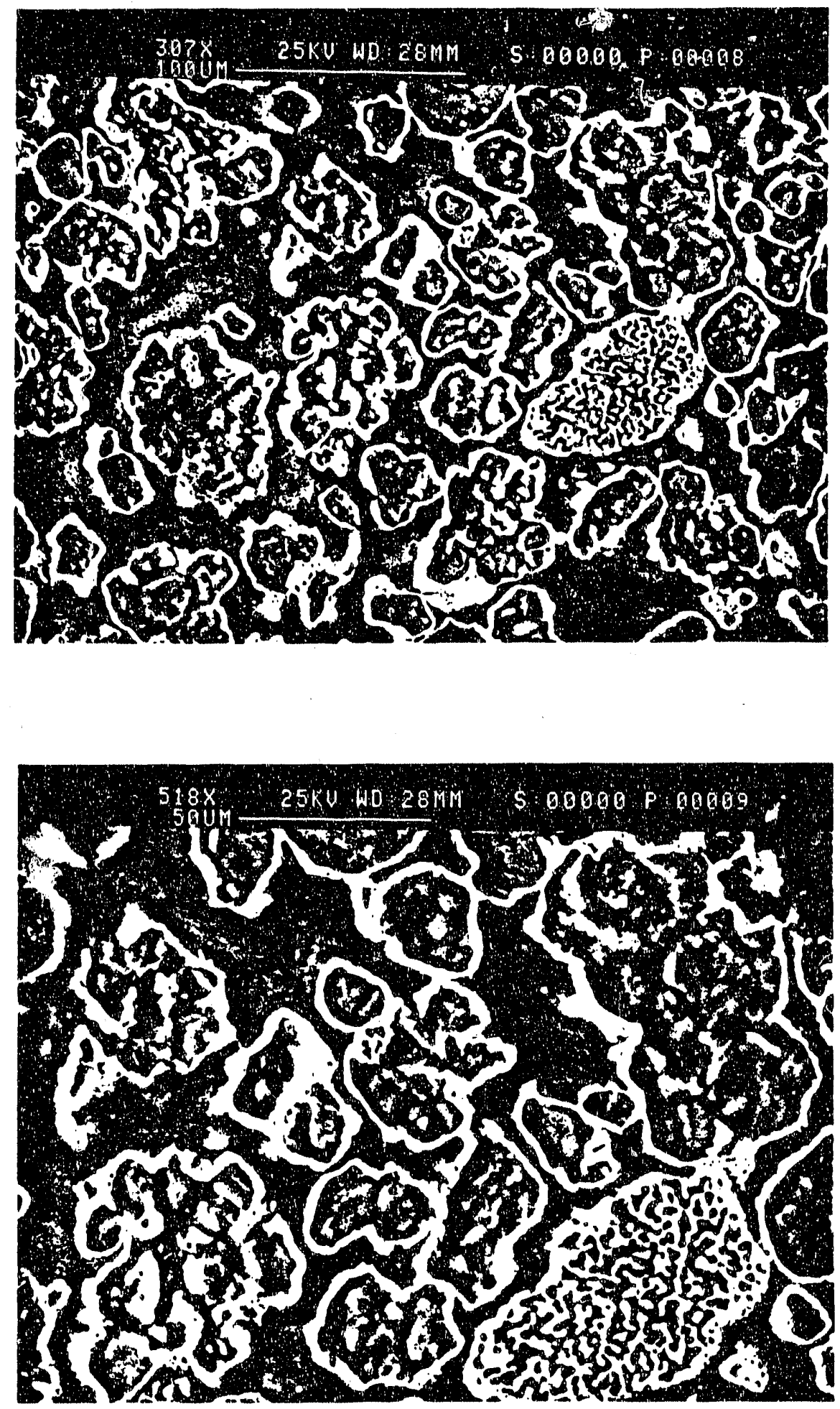

Figure 10. Cross-sectional view of sintered anode from vacuum sputter coated powder (Batch GA-9811-25) 

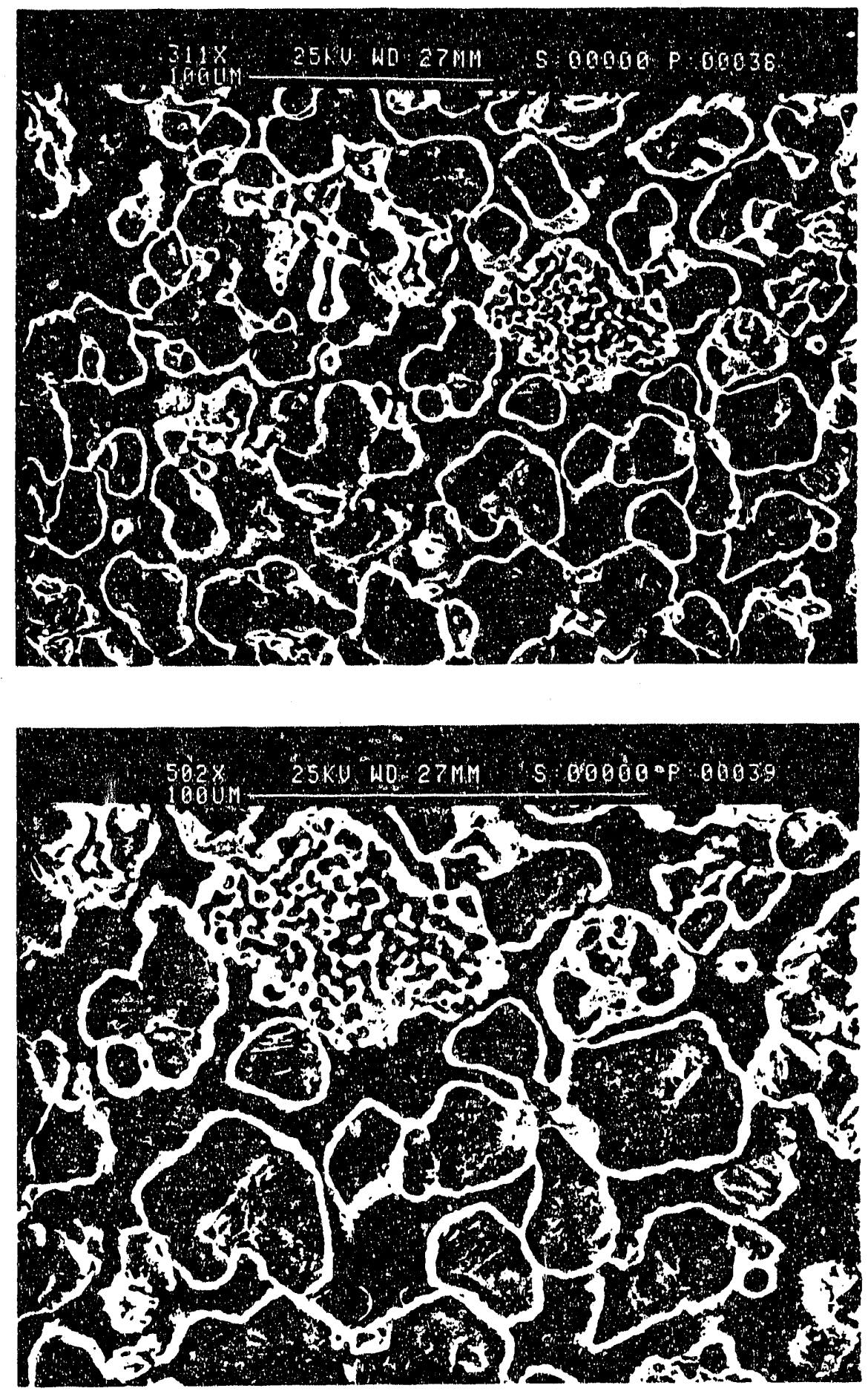

Figure 11. Cross-sectional view of post-creep tested anode srom GA 9811-25 powder 
determine the correct amount of metal-coated powder required to yield uniform porosity (45-60\%) and uniform thickness. After the process was optimized, 8 anode coupons of approximately 0.8 inch in diameter were fabricated by the gravity sintering approach. The metal coating on this batch of powder was done by the process developed by GE (see Table 4). The details of the anodes are given in Table 7.

The anodes exhibited a mean volume shrinkage of about $8 \%$ during sintering. A standard firing schedule of $925^{\circ} \mathrm{C}$ for 1 hour in $25 \% \mathrm{H}_{2} / 75 \% \mathrm{~N}$ was used. Some anode samples were analyzed for mean pore size by porosimetry. The $\mathrm{Ni}(10 \% \mathrm{Cr})$ standard was also analyzed for comparison. The metal-coated $\mathrm{LiAlO}_{2}$ anode sample had a mean pore size of about 8 microns which was close to the mean pore size of 6-7 microns for the $\mathrm{Ni}(10 \% \mathrm{Cr})$.

Anode fabrication trials were continued by the gravity sintering method with a consolidation pressure of approximately $100 \mathrm{lbs}$. The gravity sintering process was optimized by conducting several trials to determine the correct amount of metal coated powder and consolidation processes required to yield the correct porosity and thickness. After the process was optimized, 9 anode coupons of approximately 0.8 inch in diameter were fabricated. The details of the anodes are given in Table 8.

The standard firing schedule of $925^{\circ} \mathrm{C}$ for 1 hour in $25 \% \mathrm{H}_{2} / 75 \% \mathrm{~N}_{2}$ was used. Some anode samples were analyzed for mean pore size by porosimetry. The pore size average obtained was slightly large $(6-8 \mu \mathrm{m})$ compared to the $\mathrm{Ni} / \mathrm{Cr}$ staridard.

The sintered anode samples were analyzed for metal distribution by SEM. In all cases, metal dewetting is seen to occur, as aiso the iormation of metal necks between coated particles. The dot maps appear to show uniform metal distribution, but it appears difficult to interpret unambiguously cive to variations arising out of topographic effects. It appears from the SEM morphological analysis that while the metal coverage on particles appears to be continuous, it is nevoitheless globular in nature. On sintering the metal coated $\mathrm{LiAlO}_{2}$ powder to fabricate anodes, the smaller nuclei congeal to form larger metallic globules which may lead to nonuniform distribution. This could explain the brittleness and weakness of these anodes relative to the $\mathrm{Ni}(\mathrm{Cr})$ anodes. It must be emphasized, however, that these anodes are much stronger than the metal coated $\mathrm{LiAlO}_{2}$ anodes fabricated previously. They are also fairly conductive at $25^{\circ} \mathrm{C}$.

Two sets of arode coupons of approximately $0.075 \mathrm{~cm}(0.0295$ inches $)$ in thickness were fabricated for creep lesting. Anode fabrication was carried out by the gravity sintering method with a consolidation pressure of approximately $100 \mathrm{lbs}$. The standard firing schedule of $925^{\circ} \mathrm{C}$ for 1 hour in $100 \% \mathrm{H}_{2}$ was used. The details of the anodes are given in Tables $9-10$ ).

Two additional batches of metal-coated anodes were fabricated using the previously successful anode fabrication process. They indicated a 
Táble 7. Bulk Density, Thickness and Porosity of Anode Coupons

\begin{tabular}{|c|c|c|c|c|}
\hline Anode No. & $\begin{array}{c}\text { Density } \\
\mathrm{g} / \mathrm{cc}\end{array}$ & $\begin{array}{c}\text { Thickness } \\
\mathrm{cm}\end{array}$ & $\begin{array}{c}\text { Porosity } \\
\%\end{array}$ & Comments \\
\hline LA-26 I- & - & 0.135 & -- & weak \\
\hline LA-26 I-2 & -- & 0.132 & -- & weak \\
\hline LA-26 I-3 & 2.07 & 0.127 & 47 & chalky \\
\hline LA-26 I-4 & 2.15 & 0.124 & 45.7 & chalky \\
\hline LA-26 II-1 & 1.91 & 0.127 & 052 & chalky \\
\hline LA-26 II-2 & 1.81 & 0.130 & 54.4 & chalky \\
\hline LA-26 II-3 & 1.78 & 0.142 & 55.2 & chalky \\
\hline LA-26 $11-4$ & 1.85 & 0.132 & 53.5 & chalky \\
\hline
\end{tabular}

Table 8. Bulk Density, Thickness and Porosity of Anode Coupons

\begin{tabular}{|c|c|c|c|c|}
\hline Anode No. & Powder & $\begin{array}{c}\text { Density } \\
\mathrm{g} / \mathrm{cc}\end{array}$ & $\begin{array}{c}\text { Thicknes } \\
\mathrm{s} \\
\mathrm{cm}\end{array}$ & $\begin{array}{c}\text { Porosity } \\
\%\end{array}$ \\
\hline$X V-2$ & LA-39 & 0.07336 & 0.1982 & 50.04 \\
\hline$X V-3$ & LA-39 & 0.07334 & 0.1969 & 50.37 \\
\hline$X V-5$ & LA-39 & 0.07451 & 0.1930 & 51.35 \\
\hline$X V-6$ & LA-39 & 0.07620 & 0.1906 & 51.95 \\
\hline$X V I-1$ & LA-39 & 0.07027 & 0.2081 & 47.55 \\
\hline$X V I-2$ & LA-39 & 0.07218 & 0.2056 & 48.16 \\
\hline$X V 1-3$ & LA-39 & 0.07163 & 0.2070 & 47.81 \\
\hline$X V 1-4$ & LA-41 & 0.07684 & 0.1897 & 52.18 \\
\hline$X V 1-5$ & LA-41 & 0.07468 & 0.1913 & 51.77 \\
\hline$X V I-6$ & LA-41 & 0.07620 & 0.1889 & 52.39 \\
\hline
\end{tabular}

- Anodes $\mathrm{I}-1$ and $\mathrm{I}-2$ broke during characterization and hence density information could not be obtained. 
Table 9. Characterization of Metal Coated $\mathrm{LiAlO}_{2}$ Powder - batch LA41

\begin{tabular}{|c|c|c|c|c|}
\hline $\begin{array}{c}\text { Anode } \\
\text { No. }\end{array}$ & Powder & $\begin{array}{c}\text { Density } \\
\text { g/cc }\end{array}$ & $\begin{array}{c}\text { Thickness } \\
\text { mm }\end{array}$ & Porosity \\
\hline XVIII1 & LA41 & 0.0750 & 0.19098 & $51.86 \%$ \\
\hline XVIII & LA41 & 0.0752 & 0.19128 & $51.78 \%$ \\
\hline XVIII3 & LA44 & 0.0717 & 0.19090 & $51.88 \%$ \\
\hline XVIII4 & LA41 & 0.0767 & 0.19164 & $51.69 \%$ \\
\hline XVIII6 & LA41 & 0.0729 & 0.19615 & $50.55 \%$ \\
\hline XIX1 & LA44 & 0.0714 & 0.19665 & 50.43 \\
\hline XIX3 & LA41 & 0.0728 & 0.19950 & 49.69 \\
\hline XIX4 & LA41 & 0.0710 & 0.19714 & 50.13 \\
\hline XIX5 & LA41 & 0.0738 & 0.19582 & 50.64 \\
\hline XIX6 & LA41 & 0.0730 & 0.19989 & 49.61 \\
\hline
\end{tabular}

Table 10. Characterization of Metal Coated $\mathrm{LiAlO}_{2}$ Powder - Batch LA45

\begin{tabular}{|c|c|c|c|c|}
\hline $\begin{array}{c}\text { Anode } \\
\text { No. }\end{array}$ & Powder & Density & Thickness & Porosity \\
\hline XXI1 & LA45 & 0.0744 & 0.1945 & 50.97 \\
\hline XX13 & LA45 & 0.0798 & 0.1836 & 53.72 \\
\hline XX14 & LA45 & 0.0668 & 0.1995 & 49.71 \\
\hline XXI11 & LA45 & 0.0795 & 0.1875 & 52.74 \\
\hline XXI13 & LA45 & 0.0813 & 0.1800 & 54.63 \\
\hline XXI16 & LA45 & 0.0737 & 0.1900 & 52.10 \\
\hline XXVII1 & $\begin{array}{l}60 \% \text { LA45 } \\
40 \% \text { LA50 }\end{array}$ & 0.0725 & 0.1989 & 46.80 \\
\hline XXV113 & $\begin{array}{l}60 \% \text { LA45 } \\
\text { 40\%LA50 }\end{array}$ & 0.0725 & 0.2069 & 44.70 \\
\hline XXVII5 & $\begin{array}{l}60 \% \text { LA45 } \\
\text { 40\%LA50 }\end{array}$ & 0.0690 & 0.2154 & 42.40 \\
\hline
\end{tabular}


discoloration on the surface of the anodes. SEM/EDS investigation of these anodes identified the presence of sulfur in the discolored regions. The source of contamination was traced to a batch of Grafoil carbon film used to setter the anodes during the sintering process.

\subsubsection{Sintering Characteristics of $\mathrm{LiAlO}_{2}$}

For characterization purposes, the metal coated $\mathrm{LiAlO}_{2}$ powder was pressed into bars at varying pressures. The bars were sintered at three temperatures of about 750,925 and $1100^{\circ} \mathrm{C}$. The porosity, shrinkage and strength of the sintered bars were measured. The lateral shrinkage on sinteririg as a function of consolidation pressure is shown in Figure 12. The \%shrinkage behaves as expected for such porous metal-ceramic compact. At the higher sintering temperature of $1100^{\circ} \mathrm{C}$, the maximum shrinkage is $5.25 \%$; at $750^{\circ} \mathrm{C}$ the shrinkage is $3.25 \%$ at the lowest consolidation pressures of $<3 \mathrm{Kpsi}$. At the highest consolidation pressures of about $34.5 \mathrm{Kpsi}$, the maximum shrinkage occurs at $1100^{\circ} \mathrm{C}(\sim 3.5 \%)$ and the minimum occurs at $750^{\circ} \mathrm{C}(\sim 1.75 \%)$. The shrinkage in any of the conditions studied, however, is not too great to cause a concern for fabrication of these porous metal-coated ceramic compacts using the tape-casting approach. Figure 13 shows the porosity versus consolidation pressure. The results for the samples sintered at 750 and $1100^{\circ} \mathrm{C}$ show consistent results with porosity decreasing from around $55 \%$ at the low consolidation pressures to around $45 \%$ at the higher consolidation pressures. At $925^{\circ} \mathrm{C}$, the porosity shows a steady decrease from a high of $55 \%$ at $<3 \mathrm{Kpsi}$ to a low of $\sim 35 \%$ at $34.5 \mathrm{kpsi}$. This unusual behavior may be due to experimental error in maintaining the temperature. However, the implication of these results are that tape casting will definitely be a viable option for fabrication of anodes due to the porosity being well within the range of $45-60 \%$ at the lowest fabrication pressures. That is, the mean particle size and the distribution allows a packing which yields the desired porosity range with no additional forming operations. Figure 14 shows the strength of the porous compacts sintered at the three different temperatures. The strength varies with the consolidation pressure, as expected, with the higher sintering temperatures yielding stronger anode strength bars. The figure shows further that for the low consolidation pressures, the difference in the strength is smaller. Thus tape cast anodes may be fabricated at lower temperatures which will allow lesser metal migration/coalescence without significant detrimental effect to the strength of the anode.

Figures 15 and 16 show the effects of adding different binders on the densification charactelistics of the metal-coated $\mathrm{LiAlO}_{2}$ powders. The samples shown in Figure 15 were disc shaped anode coupons fabricated with glycerol as the binder. At the low consolidation pressure of about 1 ton, the porosity in the green state is about $45 \%$ and at 4 tons is about 35\%. After firing, the porosity increased by about $3 \%$ regardless of the formation pressure. The samples shown in Figure 16 were fabricated with poly-vinyl butyral as the primary binder. The behavior is fairly similar to that seen in Figure 15. 


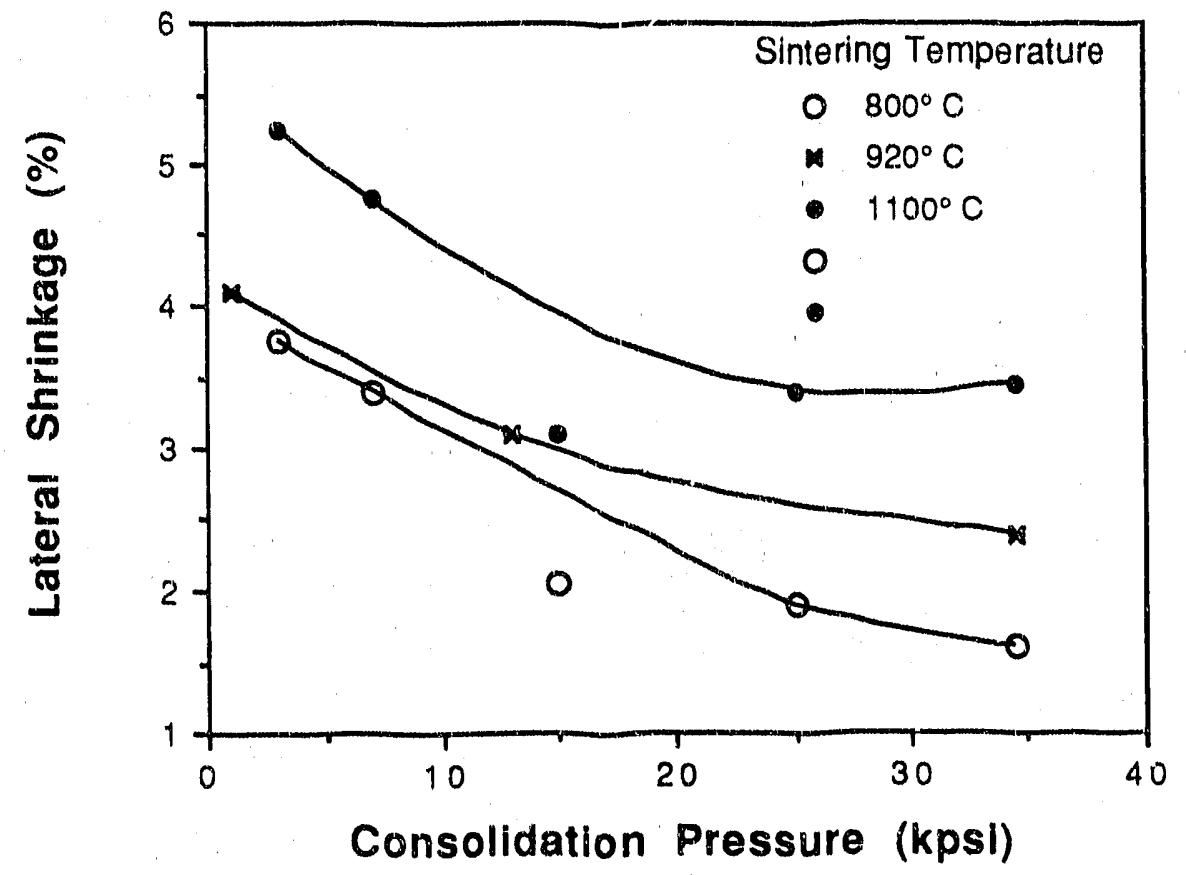

Figure 12. Lateral shrinking of metal coated $\mathrm{LiAlO}_{2}$ as a function of consolidation pressure

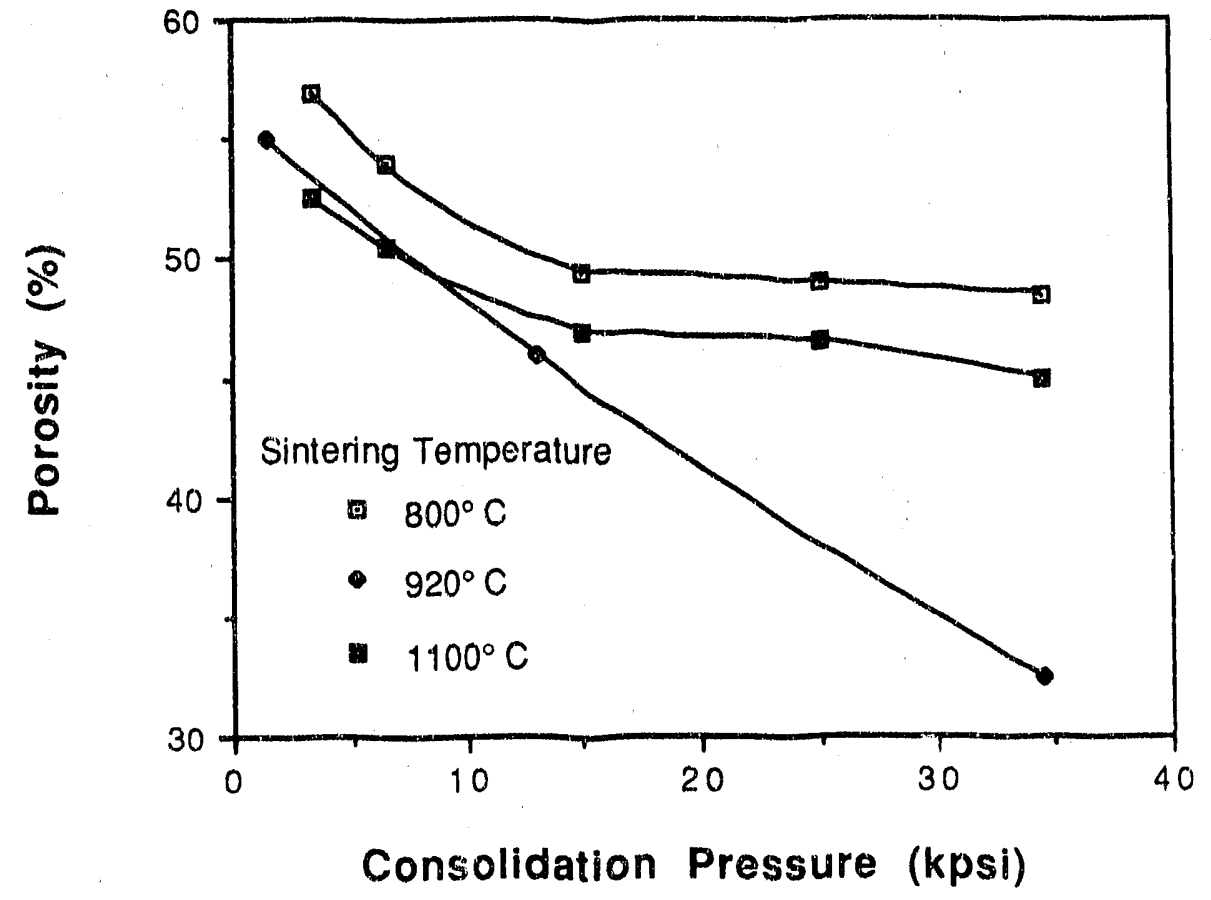

Figure 13. Porosity of metal coated $\mathrm{LiAlO}_{2}$ as a function of consolidation pressure 


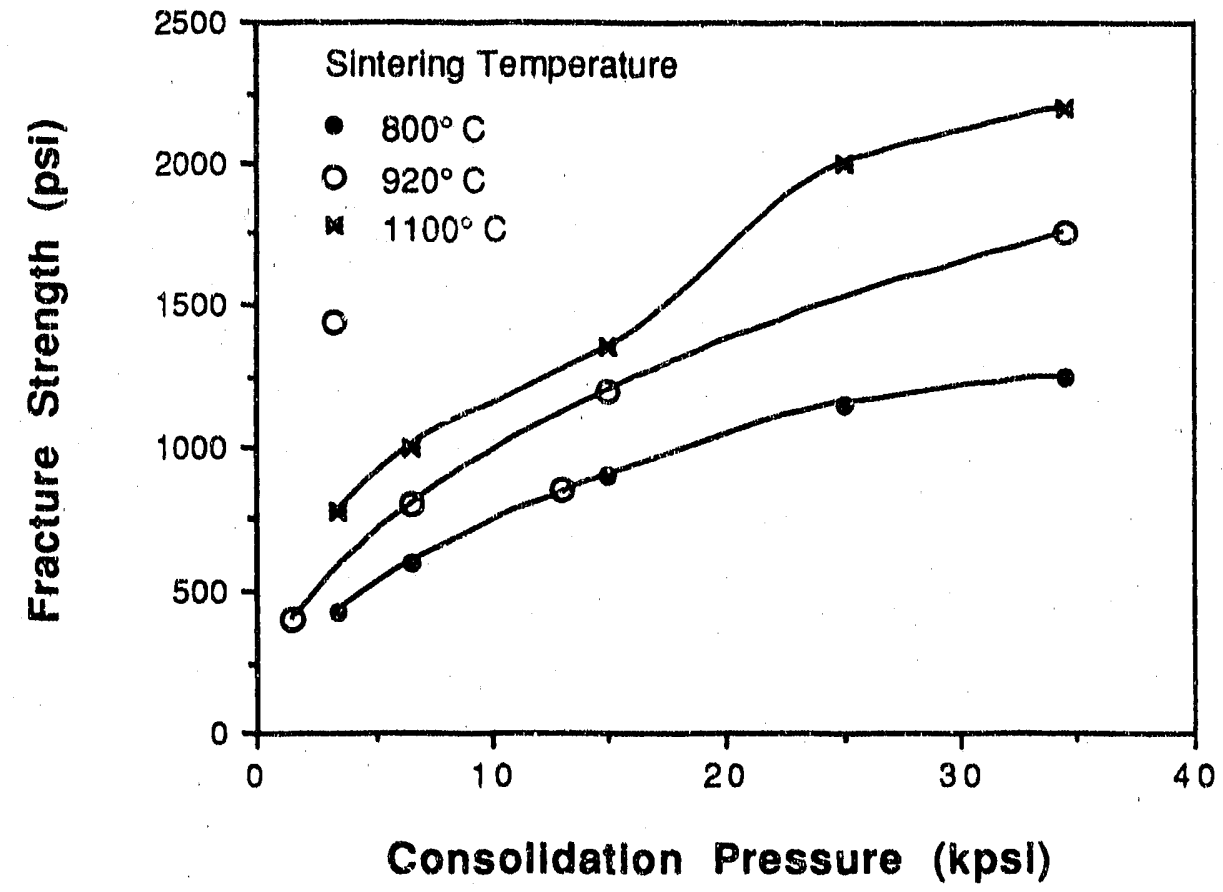

Figure 14. Fracture strength of metal coated $\mathrm{LiAlO}_{2}$ as a function of consolidation pressure

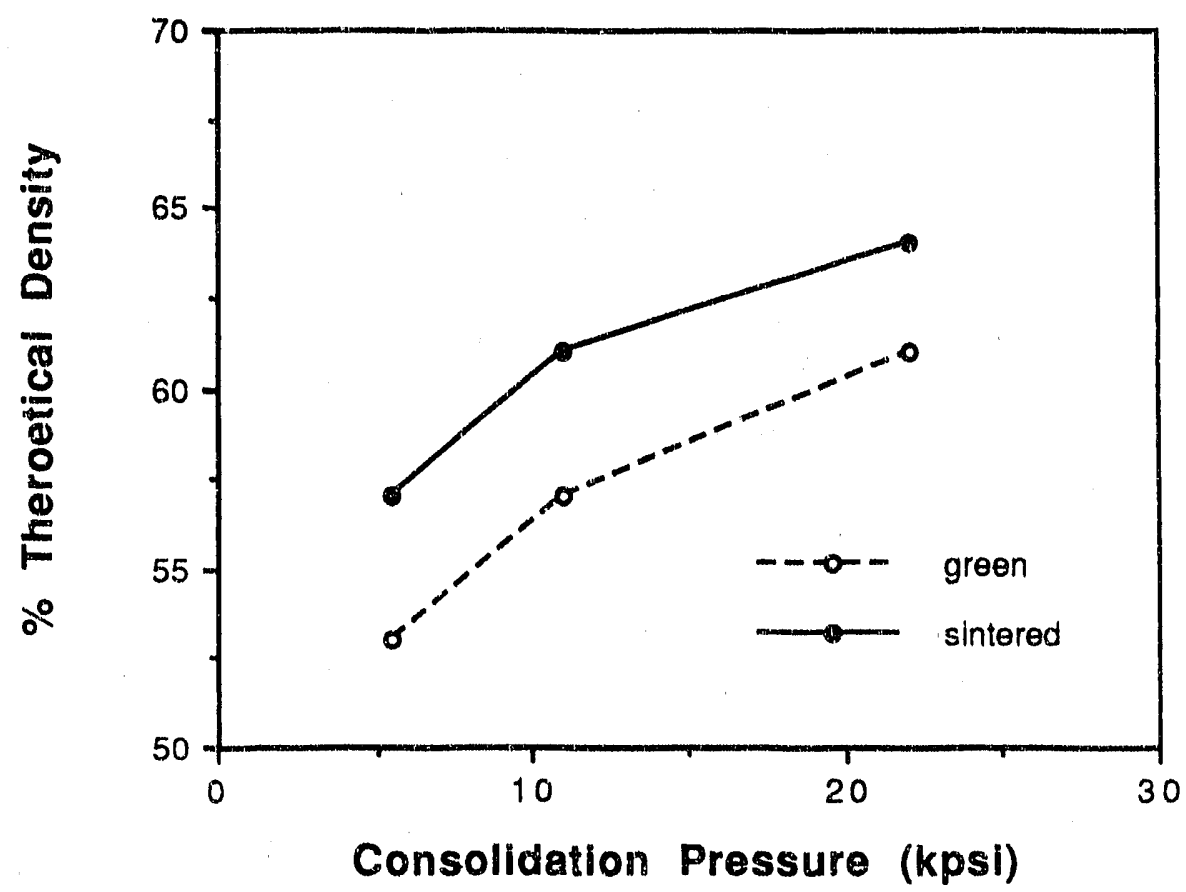

Figure 15. Density of green and fired $\mathrm{LiAlO}_{2}$ anode (Binder: Glycerol) 


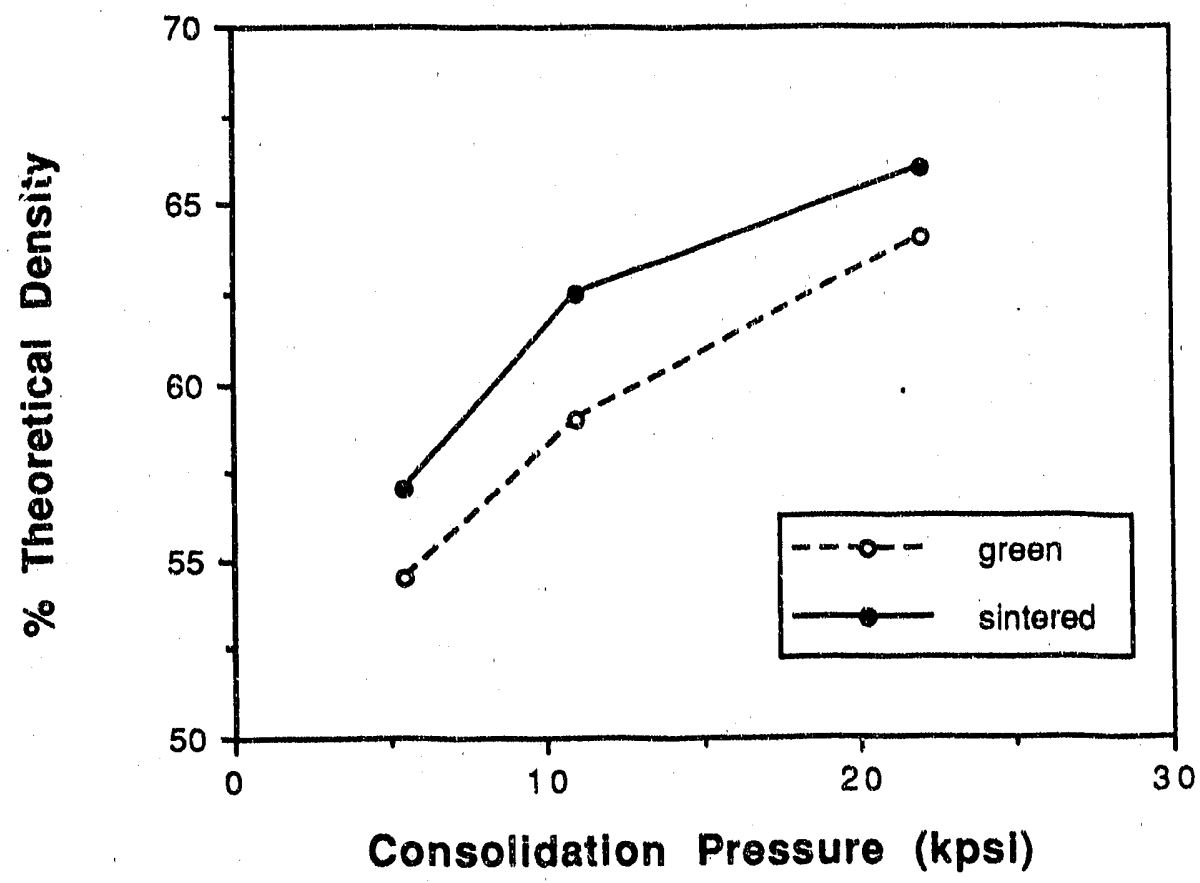

Figure 16. Density of green and fired $\mathrm{LiAlO}_{2}$ anode (Binder: PVB)

Thus, from these studies it may be concluded that the particle size is important to achieving the desired microstructure and morphological properties of the porous anodes. The effect of consolidation pressure on the properties is negligible; tape casting, thus, is a viable approach for fabrication of the large area anodes required for in-cell tests as well as for use in prototype MCFCs.

\subsubsection{Fabrication of Anode with Alternate Metal Coating Process}

Two fabrication trials were conducted on the GA powder 981125 and nine anode plaques were sent to IGT for creep testing. These trials were similar to the previously conducted anode fabrication trials with a sintering temperature of $925^{\circ} \mathrm{C}$ in a $100 \% \mathrm{H}_{2}$ atmosphere. The anodes that resulted exhibited superior metal distribution over the ceramic powder as seen by SEM examination (Figure 10). The anodes also were determined to have superior strength and conductivity to Ceramatec's previous attempts with metal coated $\mathrm{LiAlO}_{2}$.

The anodes sent to IGT were identified as LXXVI2, 4, 5, 7 and LXXVII1, 3, $4,5,6$ with an average porosity of $52.71 \%$ and a mean pore size of $16 \mu \mathrm{m}$. The pore size was too large and fabrication triais were continued to further optimize the pore size. 
Fabrication of anodes from Hilmon 602 powder were also attempted. These were also fabricated at sintering temperatures of $925^{\circ} \mathrm{C}$ in $100 \% \mathrm{H} 2$, however, these anodes were extremely chalky and weak. A higher sintering temperature may be needed because of the amount of $\mathrm{Cr}$ present in the powder.

\subsection{Tape Casting Trials}

The anode fabrication method via gravity sintering is not likely to lend itself to fabrication of anodes for actual in-cell trials. Tape casting is a potential method which allows the fabrication of thin, large area anodes with greater uniformity. IGT provided Ceramatec with their proprietary tape composition for fabrication of $\mathrm{Ni}-(10 \% \mathrm{Cr})$ anodes. This formulation uses a water soluble binder system and was determined to work well with the Ni metal powder. In the past ceramatec had tried this system with partial success. These trials were resumed and it was determined that in order to obtain a satisfactory tape, a higher binder content was needed. The modified tape composition resulted in a handleable tape of both $\mathrm{LiFeO}_{2}$ and $\mathrm{LiAlO}_{2}$ anodes. In addition, Ceramatec also pursued an organic solvent based system. This was primarily because Ceramatec had prior experience with such systems and also these systems allow higher binder contents to be used, thus allowing a tape of greater flexibility to be developed.

The critical factor in the fabrication of anodes is the use of binders that burn off without leaving carbon residue behind. The binder burn-out then could be achieved at low oxygen activity without oxidizing the metal. The strength of the metal coated anodes is governed by the formation of metal necks at the grain surfaces, and oxidation of the metal may be detrimental to the anode integrity. Thus it was decided to develop a tape with an acrylic binder system which would decompose in monomeric form leaving negligible carbon behind.

Nine different grades of acrylic binder were tried and 15 different plasticizers were used in two different solvent systems. From this large set of variations, an optimal combination of solvent, binder and plasticizer was selected for tape casting. Four tapes were made and anode samples were sintered and evaluated.

In order to achieve a more uniform microstructure in the $\mathrm{LiAlO}_{2}$ tape cast anodes, it was decided to process the green tape before sintering. A systematic study of the processing parameters on various batches of green tapes was carried out. The green tapes were pressed uniaxially at room temperature and at $43^{\circ} \mathrm{C}$; they were sintered at two different temperatures. The effect of the processing parameters (pressure and temperature at which the green tape was processed, and the sintering temperature) on the porosity values are given in Figure 17. The conditions used are listed below the figure. The results of the study can be summarized as follows: 


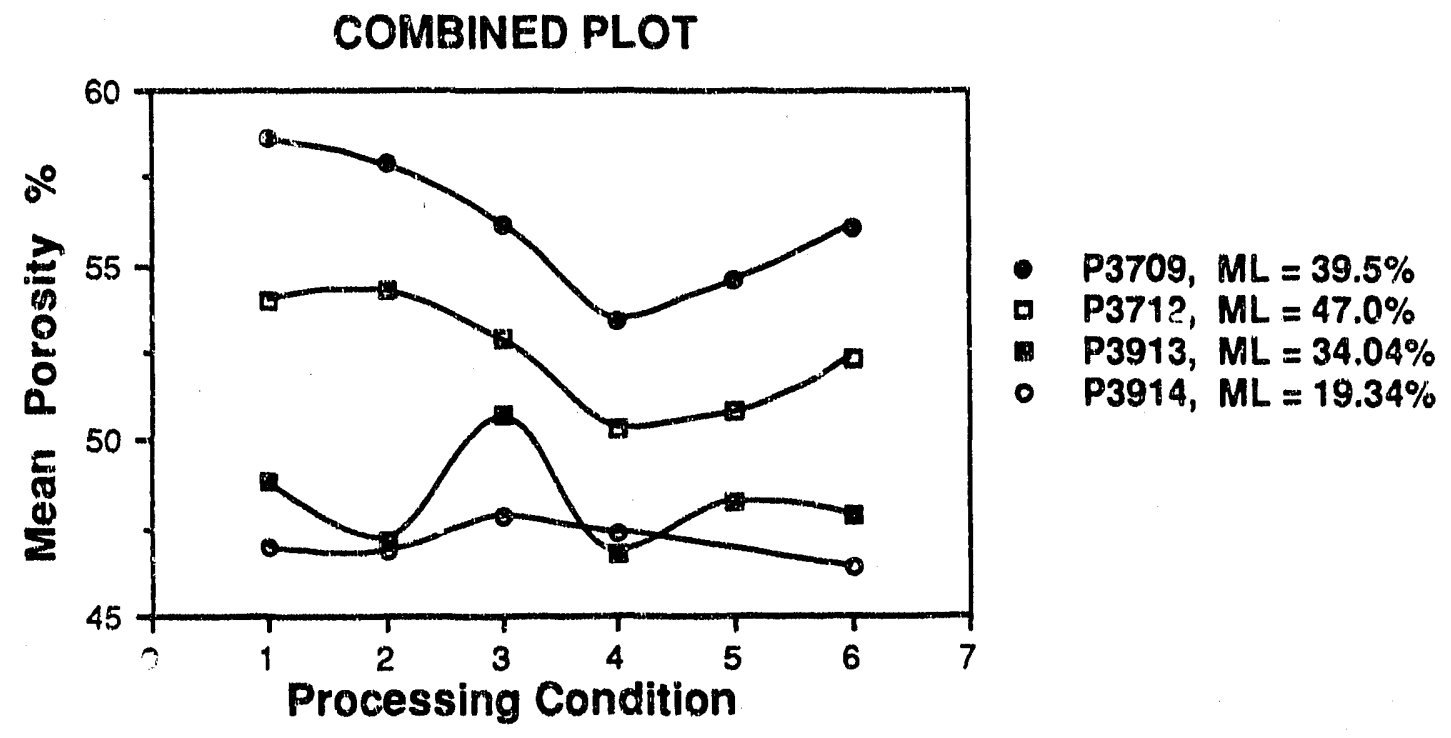

Figure 17. Effect of Processing Parameters on Mean Porosity

Processing Conditions

\begin{tabular}{|c|c|c|c|}
\hline No & $\begin{array}{c}\text { Pressure } \\
\text { psi }\end{array}$ & $\begin{array}{c}\text { Temp. } \\
{ }^{\circ} \mathrm{C}\end{array}$ & $\begin{array}{c}\text { Sinter. } \\
\text { Temp. } \\
{ }^{\circ} \mathrm{C}\end{array}$ \\
\hline 1 & 0 & 25 & 925 \\
\hline 2 & 0 & 25 & 1000 \\
\hline 3 & 500 & 25 & 925 \\
\hline 4 & 500 & 25 & 1000 \\
\hline 5 & 500 & 43 & 925 \\
\hline 6 & 500 & 43 & 1000 \\
\hline
\end{tabular}

1. Batches P3709 (39.5\% matal loading) and P3712 (37\% metal loading) had similar behavior: increase in processing pressure and/or sintering temperature of the green tape decreased the porosity of the sintered body. When the green tape was pressed warm $\left(43^{\circ} \mathrm{C}\right)$, the porosity increased with increase in sintering temperature. This may be due to the fact that the plasticizer in the green tape flowed, when the tape was pressed warm, without appreciable change in particle packing. Higher sintering temperature may have caused metal dewetting leading to increa'sed porosity.

2. Batch P3914 (19.34\% metal loading), which had the lowest metal loading, did not show much change in porosity values by varying the processing conditions. 
3. Batch P3913 (34.04\% metal loading) showed a behavior that corresponded to intermediate metal loading among the samples tested. However, a very large deviation in porosity for one sample for condition 3 resulted in high moan porosity.

A large data base consisting of the fabrication and characterization information on all the anodes fabricated was created (Appendix B). It contains information such as powder source, type and method of metal coating, metal loading, as well as processing and sintering details.

Earlier study has shown that $\mathrm{LIAlO}$ anodes with lower porosities show good creep behavior. Thus, condition 4 appears to provide the lowest porosity values for these anodes.

Several quality control plots were made for $\mathrm{LiAlO}_{2}$ anodes using the data base to determine the scatter in the characteristics that were expected to have an impact on the creep behavior. Figures $18-21$ are the quality control plots for anodes fabricated from Hilmon powder (vacuum sputtered) while figures $22-25$ are for anodes from electroless plated powder. It appears that the vacuum sputtering process allows a tighter control on the porosity of the anodes. On the other hand, electroless plated powder tends to give a wider scatter in porosity values.

\subsection{LIFeO 2 Synthesis}

$\mathrm{LiFeO} 2$ powder was synthesized using the following procedure: $\mathrm{Li}_{2} \mathrm{CO}_{3}$ and $\mathrm{Fe}_{3} \mathrm{O}_{4}$ were mixed in stoichiometric proportions and ball milled for 12.14 hours in ethanol. The mixture was then dried and calcined in a crucible in air at $1200^{\circ} \mathrm{C}$ for 10 hours. The resulting agglomerated powder was ball milled for 2 hours and recalcined at $1200^{\circ} \mathrm{C}$ for 10 hours to insure complete reaction and homogeneity. The synthesized powder was characterized by XRD to confirm the $\mathrm{LiFeO}_{2}$ phase.

Among the two large $(\sim 1 \mathrm{~kg})$ batches of $\mathrm{LiFeO}_{2}$ syrithesized the first batch was found to be a mixture of alpha- $\mathrm{LiF}_{\theta} \mathrm{O}_{2}$ and alpha-Lit" ${ }_{5} \mathrm{O}_{8}$; the $\mathrm{Li}$ deficient phase, alpha- $\mathrm{LiF}_{{ }_{5} \mathrm{O}_{8}}$, results from a loss of lithia during calcination/ reactivesintering cycles during synthesis. The second batch was synthesized in an effort to achieve a single phase of $\mathrm{LiFeO}_{2}$. During the sintering cycles some $\mathrm{Li}_{2} \mathrm{CO}_{3}$ was sprinkled on top of the powder to maintain a high $\mathrm{Li}$ activity over the powder mass, in order to avoid the loss of lithia. The top layer of the powder was discarded and the resi of the powder was milled to break up agglomerates and then characterized by XRD. This powder was characterized to be single phase alpha- $\mathrm{LiF}_{\theta} \mathrm{O}_{2}$.

\subsection{LiFeU2 Platina Trials}

Several plating trials were attempted using the $\mathrm{LiFeO}_{2}$ and $\mathrm{LiFe}_{5} \mathrm{O}_{8}$ mixture and the results of these plating runs are listed in Table 11. 


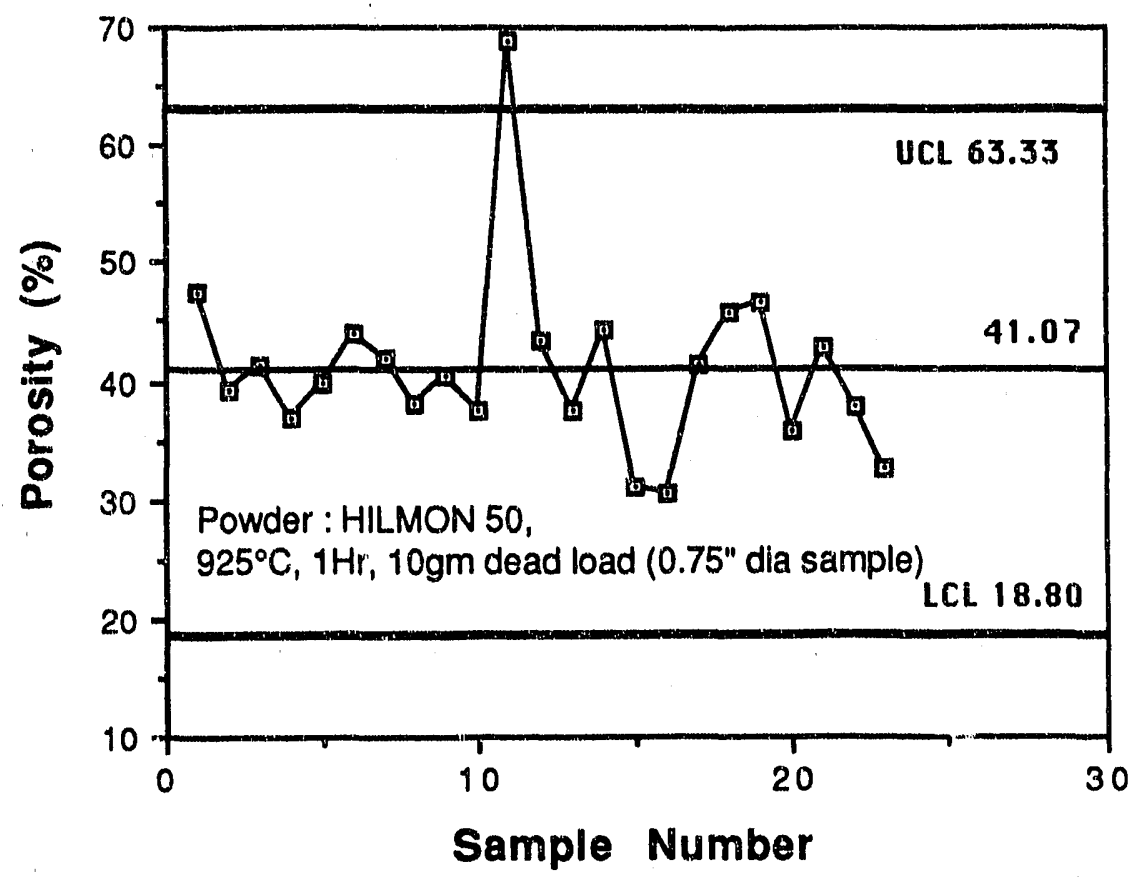

Figure 18. Scatter in porosity values for gravity sintered anode from Hilmon powder

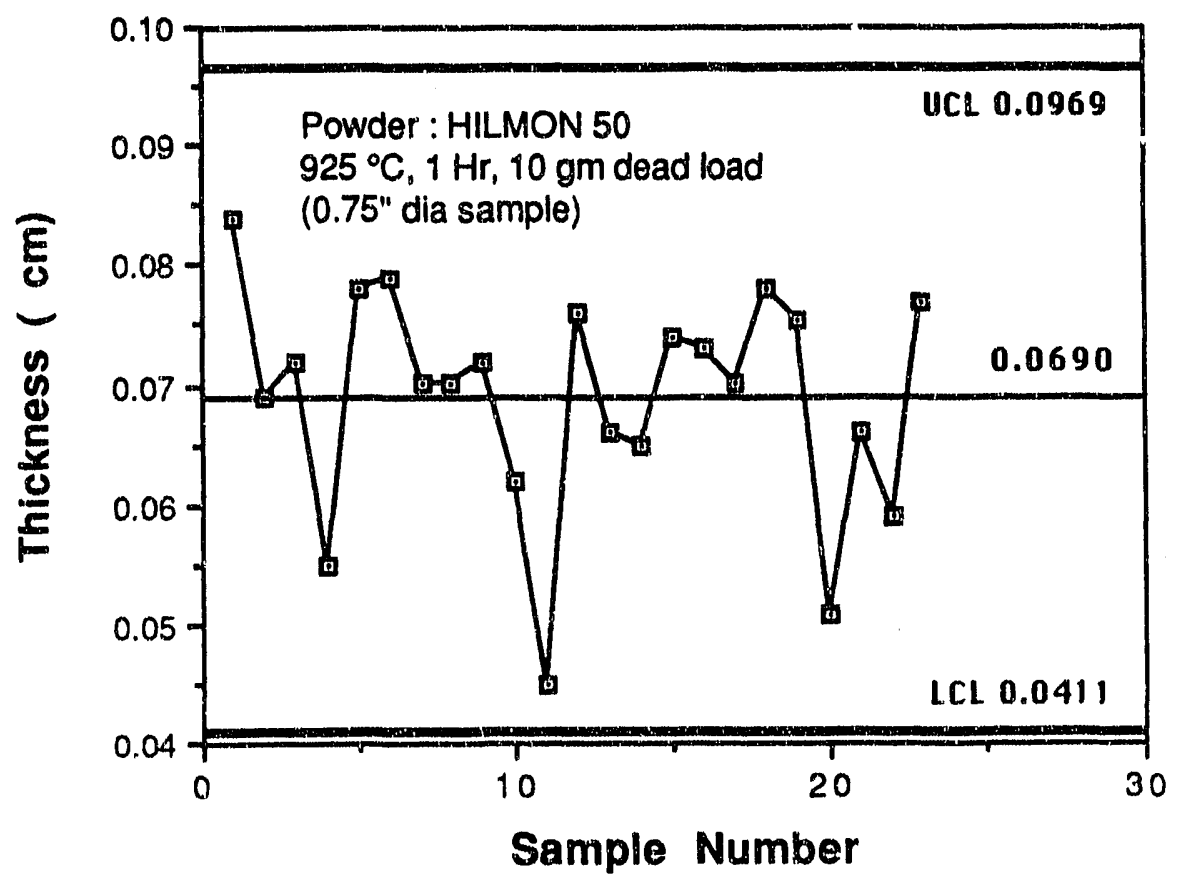

Figure 19. Scatter in thickness values for gravity sintered anode from Hilmon powder 


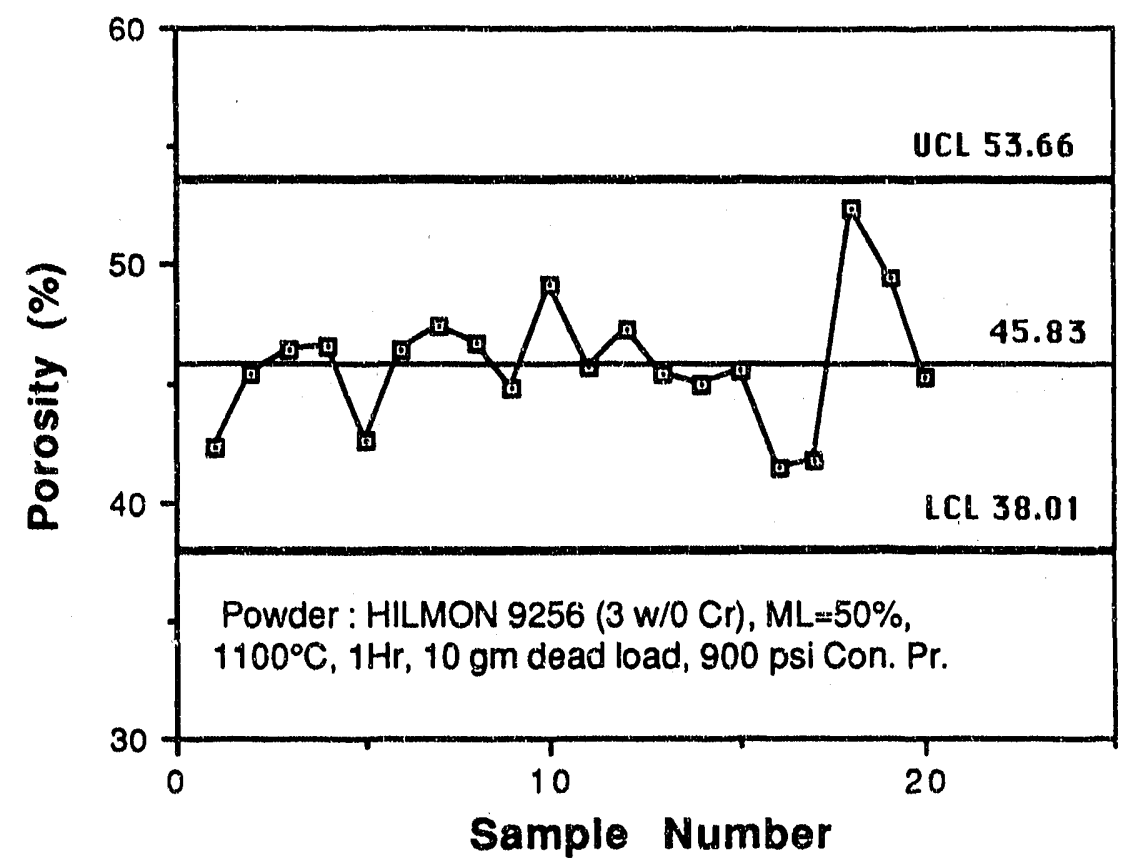

Figure 20. Scatter in porosity values for anode from Hilmon powder (sintered with consolidation pressure)

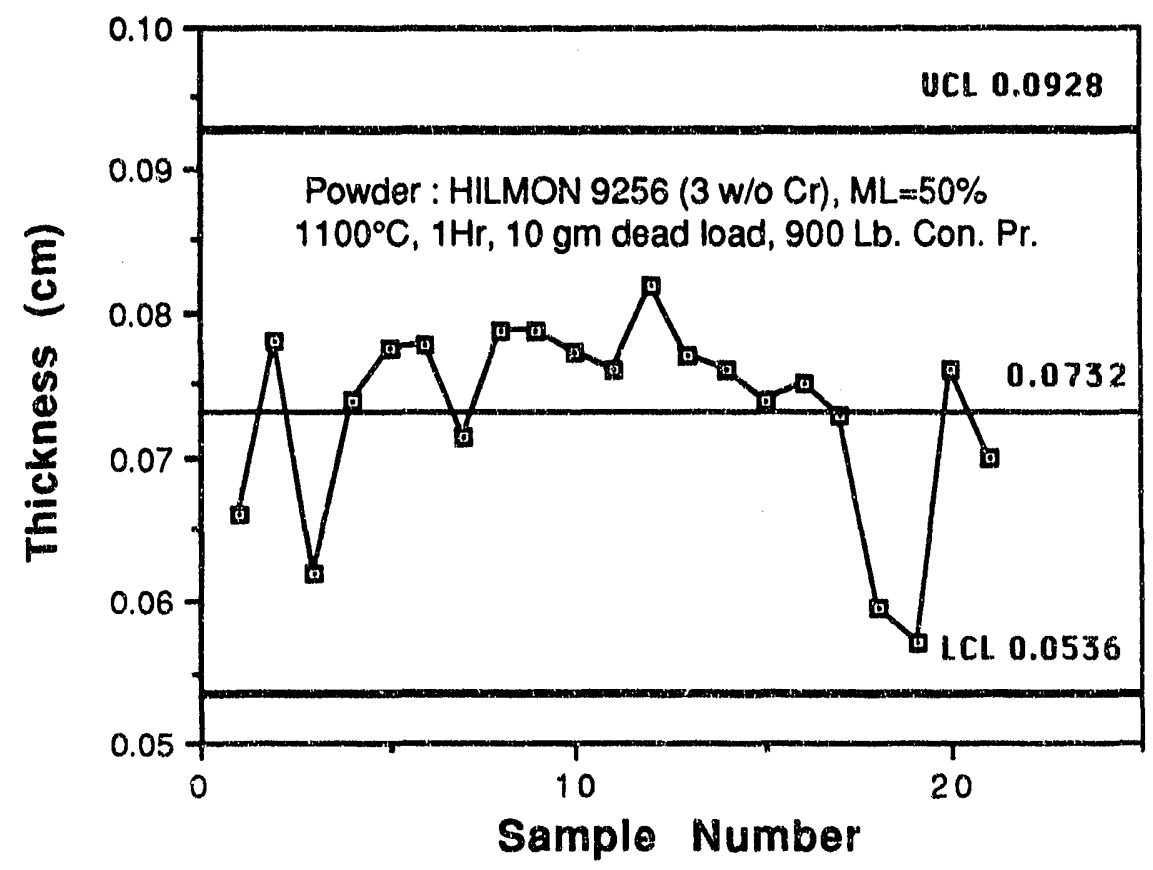

Figure 21. Scatter in thickness values for anode from Hilmon powder (sintered with consolidation pressure) 


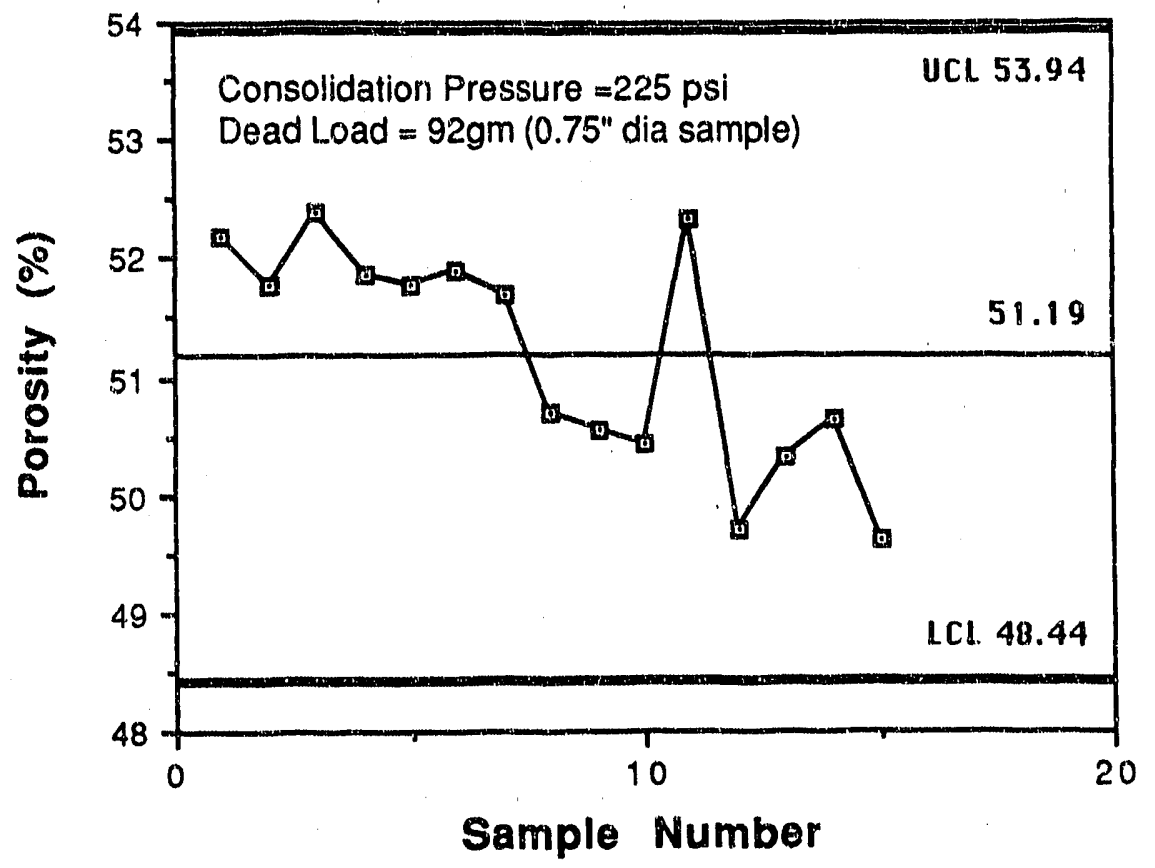

Figure 22. Scatter in porosity values for anode from electroless plated powder (sintered with consolidation pressure, $44.3 \%$ metal loading)

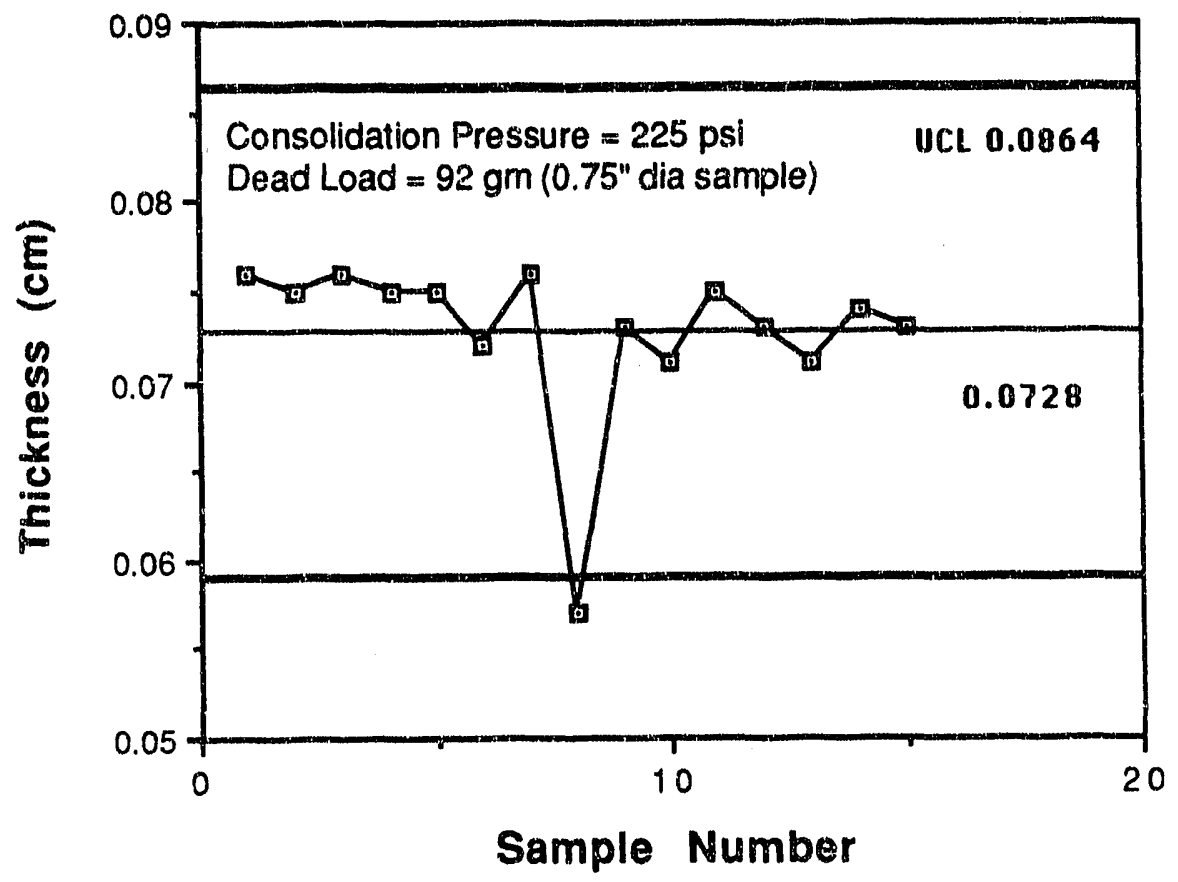

Figure 23. Scatter in thickness values for anode from electroless plated powder (sintered with consolidation pressure, $44.3 \%$ metal loading) 


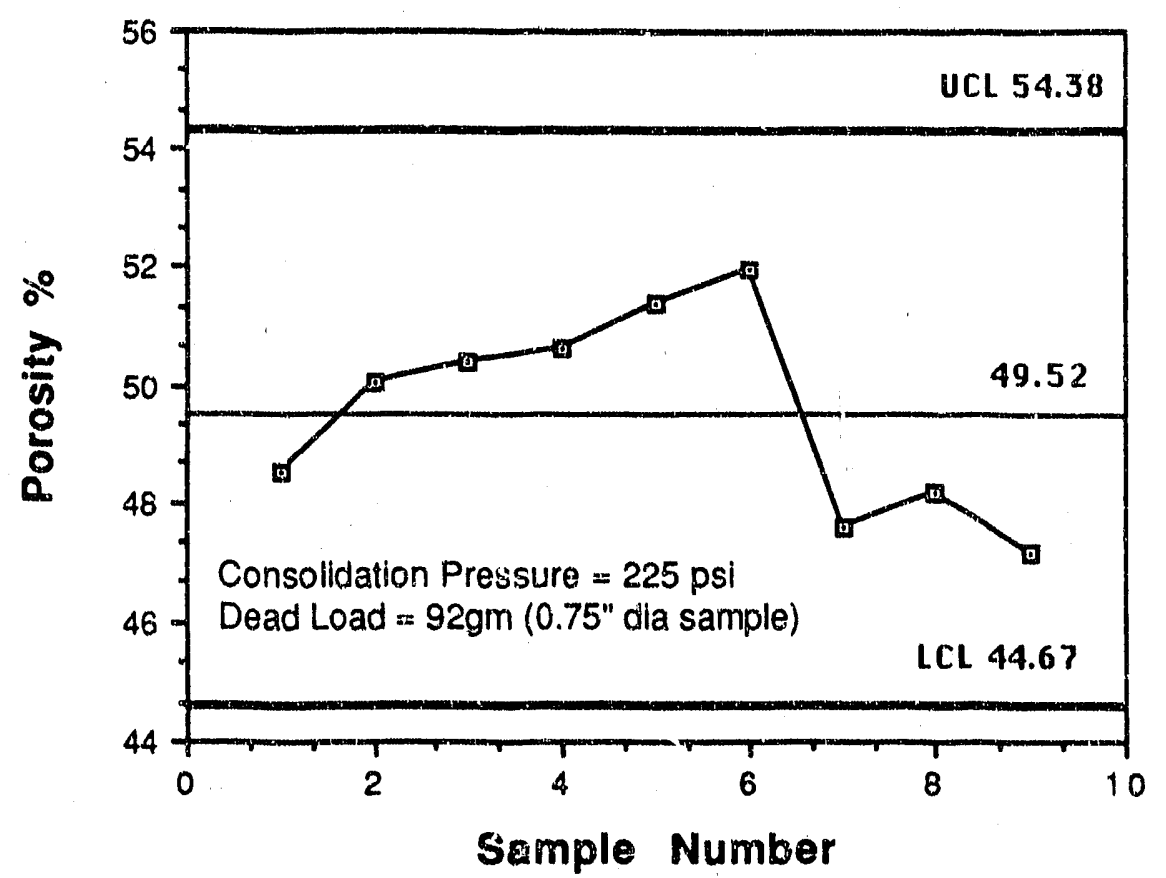

Figure 24. Scatter in porosity values for anode from electroless plated powder (sintered with consolidation pressure, $44.7 \%$ metal loading)

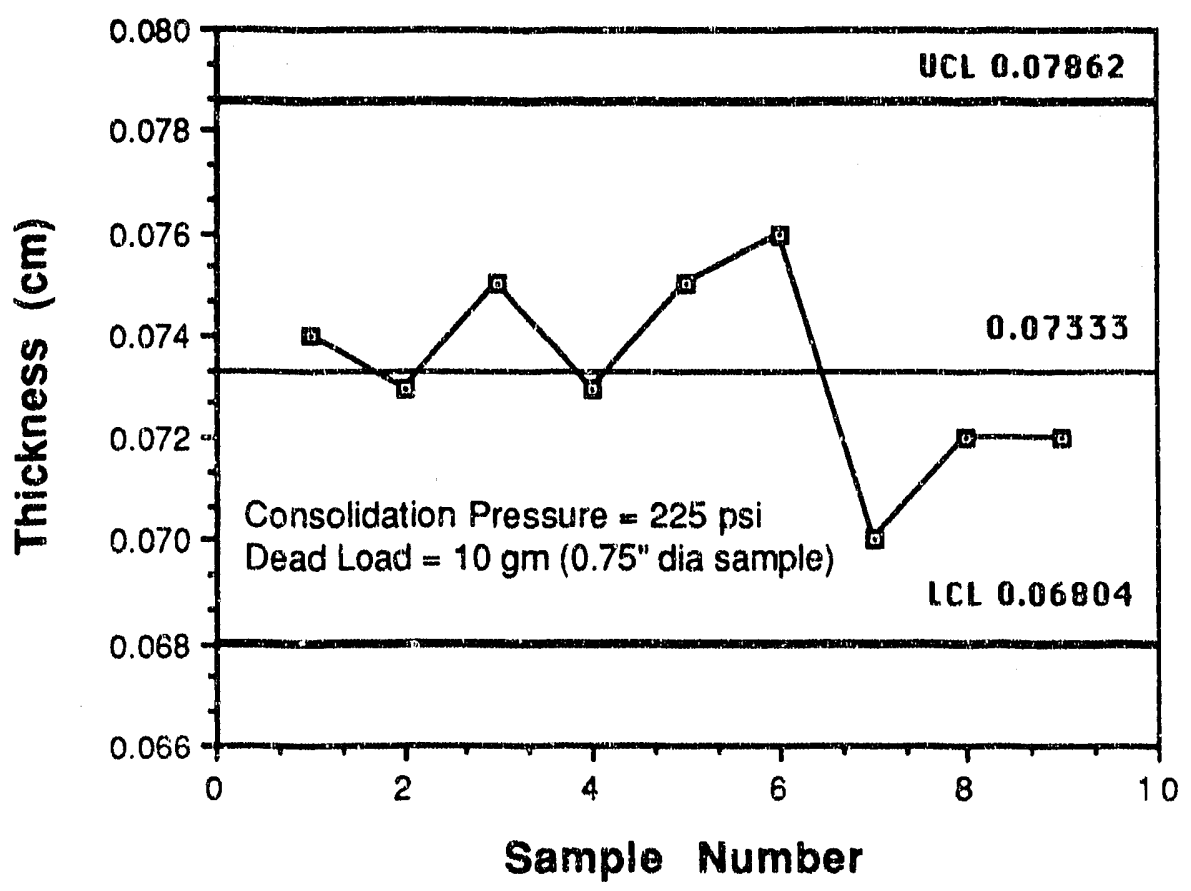

Figure 25. Scatter in thickness values for anode from electroless plated powder (sintered with consolidation pressure, $44.7 \%$ metal loading) 
Table 11. Metal Loading of Metal Coated LiFeO 2 Powder

\begin{tabular}{|c|c|c|c|}
\hline Powder & $\% \mathrm{Cu}$ & $\% \mathrm{Ni}$ & $\begin{array}{c}\text { Total Metal } \\
\%\end{array}$ \\
\hline LF1 & 22.60 & 38.20 & 60.80 \\
\hline LF2 & 22.28 & 40.80 & 64.08 \\
\hline LF3 & 31.45 & 35.60 & 67.05 \\
\hline LF4 & 22.05 & 29.55 & 51.60 \\
\hline
\end{tabular}

\subsection{Sintering Trials on Cu/Ni Coated $\mathrm{LiFeO}_{2}$}

The past efforts were centered principally on gravity sintering of metal coated ceramic powders and prepressing at various pressures followed by gravity sintering. SEM examination of the sintered anodes showed that while the particles were of the approximate size range compatible with achieving the desired anode specifications, the packing of the particles was not optimal. A "honeycomb" type structure was formed due to interparticle necking of the metal deposits. This resulted in large agglomerates with large open pores.

Efforts were centered around adding binders to the metal coated ceramic powders and prepressing them to different pressures. In addition to these trials, two more trials were conducted using a magnetic field to align the particles in the graphite die. This was to investigate whether a better and more uniform particle packing could be obtained.

The parameters are tabulated in Table 12.

These samples were analyzed to determine if there was any trend or relationship between fabrication conditions and the resulting density and mean pore size (mps). A porosity of 50 to $60 \%$ with a mean pore size of $35 \mu \mathrm{m}$ are desired for a state-of-the-art anode. It was found that the specimens analyzed from each sample were grossly different in terms of porosities and mps. That is, sample specimens taken from one part of the larger samples were not the same as sample specimens from another part. It is believed that this is due to variations in the pore structure.

Variations in the thickness of the plaques of $5-8$ mils were observed. Generally, the samples were thinnest at the center and thickest at the edges. The variations in plaque thickness may be a source of density gradients within the samples. Since a variance of 5 mils in the thickness of a plaque would prohibit the collection of meaningful data from creep tests, these plaques were not creep tested.

Furthermore, bulk density values obtained by porosimetry are consistently greater than those obtained by geometry. This is probably the result of the fact that the volume of the sample obtained by porosimetry is less 
Table 12. Sintering Variations for Anode Fabrication Trials

\begin{tabular}{|c|c|l|}
\hline Sample Code & Sample ID & Sintering Conditions \\
\hline 31 & $5 N F 140$ & $\begin{array}{l}0.2 \text { w/O PVB in acetone; } 250 \text { psi } \\
\text { (consolidation pressure; 126 } \\
\text { g.load; gravity sintering. }\end{array}$ \\
\hline 32 & 5 NF140 & $\begin{array}{l}\text { (LiFeO2 with 0.5 w/o Elvacite) } \\
250 \text { psi consolidation pressure; } \\
126 \text { g load; gravity sintering. }\end{array}$ \\
\hline 33 & $5 N F 142$ & $\begin{array}{l}\text { vibratory packing in mag.field; } \\
100 \text { psi consolidation pressure; } \\
\text { hot press T=925 C, 1000 psi }\end{array}$ \\
\hline 34 & vNF142 & $\begin{array}{l}\text { vibratory packing in mag.field; } \\
100 \text { psi consolidation pressure; } \\
126 \mathrm{~g} \text { load; gravity sintering } \\
\left(\mathrm{T}=925^{\circ} \mathrm{C}\right)\end{array}$ \\
\hline
\end{tabular}

than the volume calculated from the sample dimensions. This could be due to the irregular shape of the plaques and the fact that the $\mathrm{Hg}$ would fill any depressions or large pores at the sample surface. The skeletal (material) densities obtained by porosimetry are much greater than the calculated values. This may indicate that more than $50 \mathrm{wt} \%$ metal is present in the plaques.

In order to determine the cause of the high metal loading on the sintered samples, the following experiments were carried out: The possibility of $\mathrm{L}$.iFeO being reduced in contact with carbon due to a local $\mathrm{CO} / \mathrm{CO}_{2}$ equilibrium was tested. This condition could arise due to the graphite dies and Grafoil shims currently being used to sinter the coated powders; access of the flowing $90 \%$ Ar- $10 \% \mathrm{H}_{2}$ gas ambient to the powder may be restricted. To test this possibility, uncoated $\mathrm{LiFeO}_{2}$ was placed in a graphite die with a Grafoil cover and subjected to a sintering cycle similar to that of an actual metal-coated powder sintering cycle. The starting powder was identified by XRD to be predominantly the alpha-LiFeO $\mathrm{O}_{2}$ phase. After the sintering cycle, the powder appeared to have reacted with the graphite adhering tenaciously to the substrate. An XRD pattern taken on the sample after the sintering cycle indicates peaks corresponding to the $\mathrm{FeC}$ phase (predominant). Peaks corresponding to the alpha, beta and gamma phases of $\mathrm{LiFeO}_{2}$ were also identified.

The third batch of seven sintered anode samples were analyzed for porosity and pore size distribution and were found to have large pores. Because the pore size has been consistently larger than the desired pore size despite having the optimal particle size distribution (10 - 15 micron), it was decided to reduce the starting particle size. Consequently an effort to produce $\mathrm{LiFeO}_{2}$ particle with three different size ranges smaller than the $10-15$ micron range was started. The size ranges chosen were centered around 10 microns, 5 microns and $1-5$ microns. Two methods were chosen to mill the powder to 
the desired ranges. The first method was ball milling and the second was vibratory milling. The size distribution is expected to be different in the two cases and hence the particle packing. Thus, it is expected that these sized powders when plated and sintered will lead to different anode morphologies.

A total of 11 different anode specimens were fabricated and the processing conditions are listed in Table 13.

\subsubsection{Fabrication Characteristics of Metal-coated LiFeO2 Powders}

Three anode fabrication trials were conducted to determine the shrinkage and porosity characteristics of metal-coated $\mathrm{LiFeO}_{2}$ porous compacts. The shrinkage of the $\mathrm{LiFeO}_{2}$ anodes is considerable as compared to the $\mathrm{LiAlO}_{2}$ anodes. As shown in Figure 26, the mean shrinkage upon firing at $925^{\circ} \mathrm{C}$ for $1 \mathrm{hr}$ is $36 \%$ for a consolidation pressure of about $150 \mathrm{psi}$. The porosity of these anodes varies from approximately 48 to $54 \%$. For anodes made at different consolidation pressures and fired at $1100^{\circ} \mathrm{C}$ for $1 \mathrm{hr}$, the shrinkage varies from about $32 \%$ for a consolidation pressure of about 440 psi to a high of about $38 \%$ at $6.6 \mathrm{Kpsi}$. The porosity variation, shown in Figure 27 , is as expected with the highest porosity being exhibited by the anode fabricated at the lowest consolidation pressure.

In the past, $\mathrm{LiFeO}_{2}$ anodes had exhibited a morphology which indicated that the $\mathrm{LiFeO}_{2}$ grains were themselves sintering together. This was speculated to result in the high strength of the porous anodes. The results were used to develop and fabricate $4 " \times 4 "$ anodes for in-cell testing at IGT.

\subsubsection{Synthesis of Metal-coated LiFeO2 Tape Cast Anodes}

IGT fabricated several anodes by tape casting metal coated $\mathrm{LiFeO}_{2}$ powder supplied by Ceramatec. The resultant tapes were thin and very fragile. Four tapes were pressed together at 10,000 psi. Several anodes 1 " in diameter were punched from the plaque. The geometric densities (i.e., sample weight/sample volume) of the anodes were between 3.45 and $3.89 \mathrm{~g} / \mathrm{cc}$. A median pore size of 1.24 and a porosity of $46.4 \%$ was determined by the porosimetry of one of the anodes. The skeletal density obtained was $8.18 \mathrm{~g} / \mathrm{cc}$ which may indicate that the powder used was composed primarily of $\mathrm{Cu}$ and $\mathrm{Ni}$.

For the purpose of conducting the in-cell tests, it was necessary to fabricate the larger 4 " $\times 4$ " anodes for in-cell testing and evaluation. To this end Ceramatec synthesized a large batch of $\mathrm{LiFeO}_{2}$ powder and initiated metal coating of this powder. Metal-coated $\mathrm{LiAlO}_{2}$ powder was used to cast a 8" wide tape. Three large green $\mathrm{LiAlO}_{2}$ tape blanks were cut and sent to IGT for subsequent in-cell testing. These were cut after consideration of the linear and vertical shrinkage factors that were studied during the earlier studies on metalcoated $\mathrm{LiAlO}_{2}$ anodes. A green tape of metal-coated $\mathrm{LiFeO}_{2}$ was also sent to IGT. 
Table 13. Fabrication of Metal Coated $\mathrm{LiFeO}_{2}$ Anodes

\begin{tabular}{|c|c|}
\hline $\begin{array}{c}\text { Sample } \\
\text { No }\end{array}$ & Processing Condition \\
\hline $4-1$ & $\begin{array}{l}10 \mu \mathrm{m}, \mathrm{LiFeO}, 250 \mathrm{psi} \text { consolidation pressure, } 126 \text { g.dead } \\
\text { load, } \mathrm{T}=920^{\circ} \mathrm{C} ; 0.5 \mathrm{w} / \mathrm{o} \text { binder. }\end{array}$ \\
\hline $4-2$ & same as above but with $\sim 0.7$ w/o binder. \\
\hline $4-3$ & $\begin{array}{l}10 \mu m_{1} \text { LiFeO } \\
\text { load, } T=920^{\circ} \mathrm{C} \text {. }\end{array}$ \\
\hline $4-4$ & same as 4-3 but with 250 psi consolidation pressure. \\
\hline $4-5$ & $10 \mu \mathrm{m}$, vibratory milled $\mathrm{LiFeO}_{2}$. \\
\hline $4-6$ & $10 \mu \mathrm{m}$, ball milled LiFeO \\
\hline 4-7 & $\begin{array}{l}10 \mu \mathrm{m} \text {, ball milled } \mathrm{LiFeO}_{2} \text {, coated powder crushed lightly in } \\
\text { a mortar before sintering to break up necks between } \\
\text { particles. }\end{array}$ \\
\hline $4-8$ & $5 \mu \mathrm{m}$, ball milled LiFeO 2 \\
\hline $4-9$ & $1 \mu \mathrm{m}$, vibratory milled $\mathrm{LiFeO}_{2}$. \\
\hline $4-10$ & sub-1 $\mu \mathrm{m}$, vibratory milled $\mathrm{LiFeO}_{2}$. \\
\hline $4-11$ & $1 \mu \mathrm{m}$, ball milled $\mathrm{LiFeO}_{2}$ Samples \\
\hline
\end{tabular}

4-5 through 4-11 were consolidated at $250 \mathrm{psi}$ and sintered at $920^{\circ} \mathrm{C}$. All of the above samples were sintered in a 90\% Argon-10\% hydrogen atmosphere. 


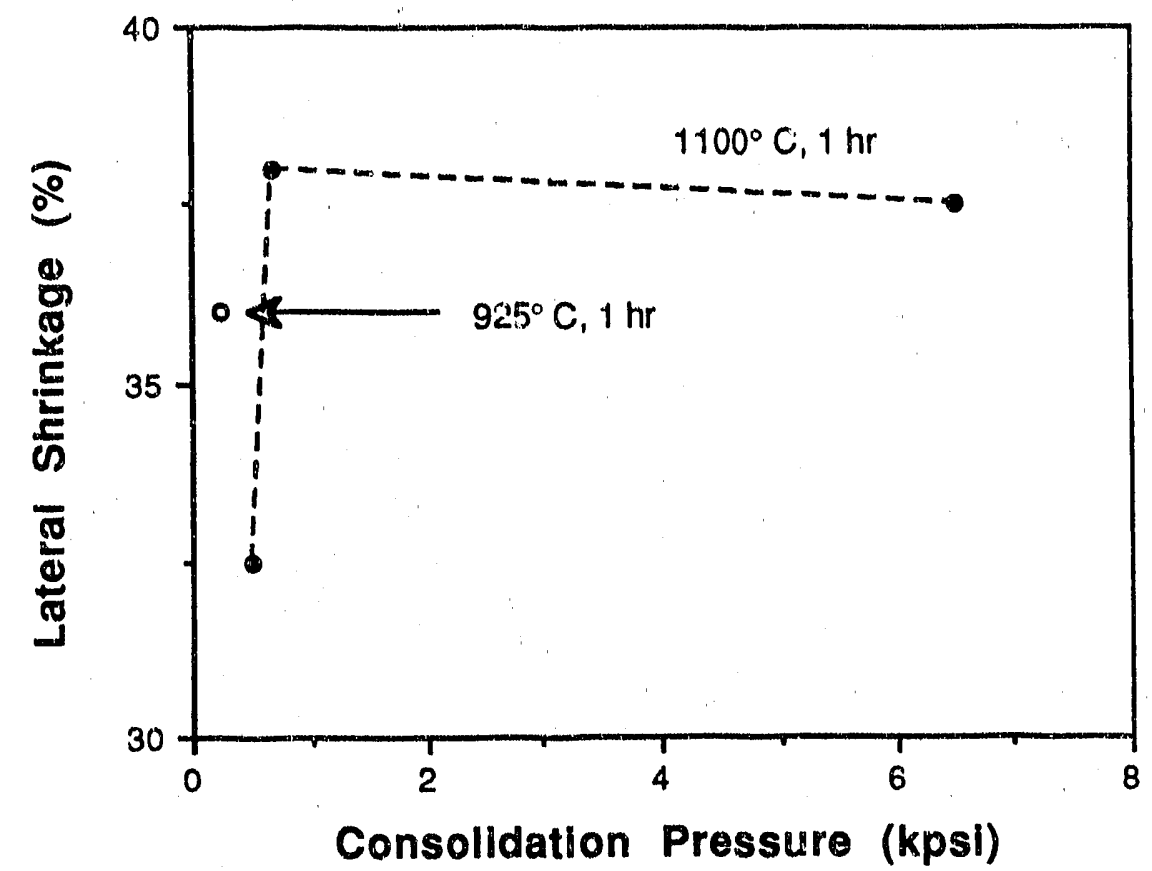

Figure 26. Effect of sintering temperature on the shrinkage of $\mathrm{LiFeO}_{2}$ anodes

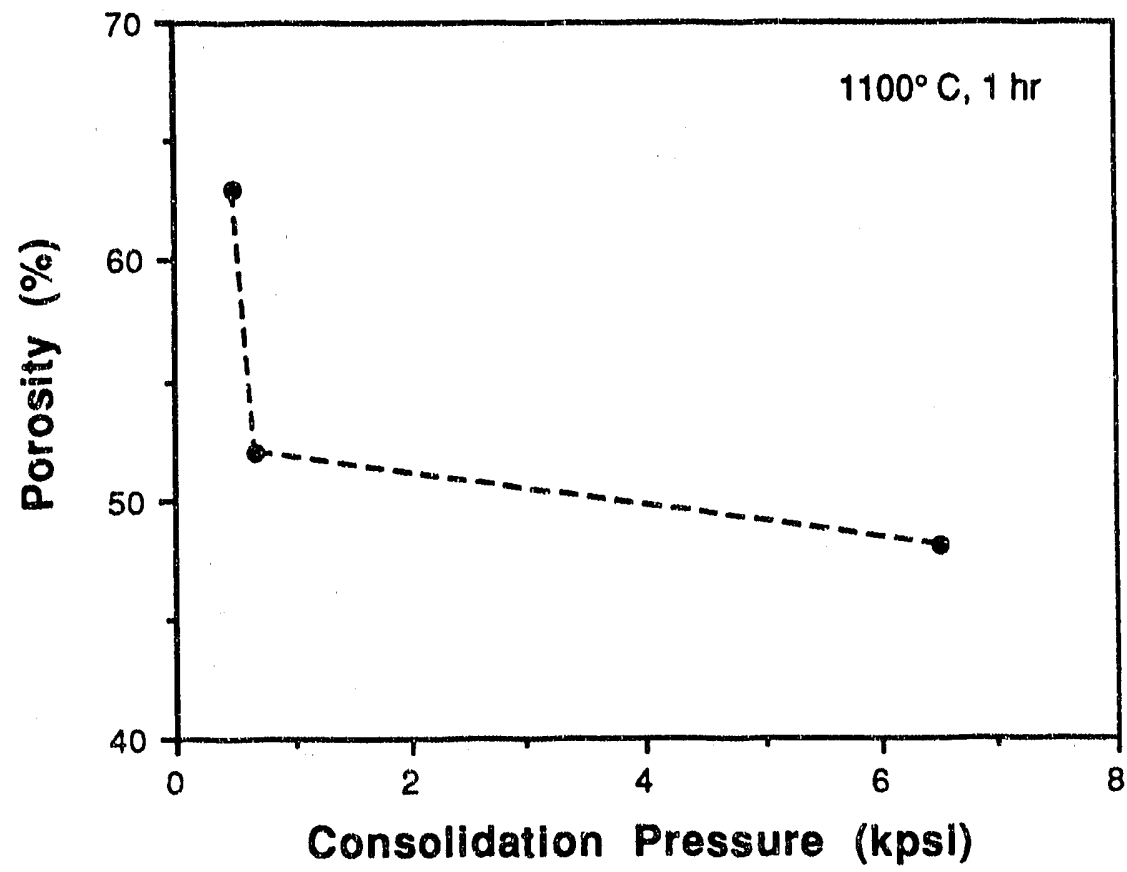

Figure 27. Effect of sintering consolidation pressure on the shrinkage and porosity of $\mathrm{LiFeO}_{2}$ anodes 


\subsection{CREEP TESTING}

Three creep test stands were constructed for determining the deformation (creep) of porous anodes. The test stands were designed to follow the creep of the anodes during the test. Becal', $\theta$ the creep test screening was of a short duration ( 170 hours), the shape of the creep curves is important for extrapolation of the creep data for longer periods. In addition, it was expected that the indicated creep would be exactiy the same as that actually measured for the sample after the test. For a variety of reasons, agreement between the actually measured creep and the indicated creep value was not obtained. Therefore, the creep was determined by comparing the pre- and post. test sample thickness.

In order to span the region of possible temperature and compressive forces that a porous anode could encounter in an operating fuel cell, two temperatures $\left(650^{\circ}\right.$ and $\left.700^{\circ} \mathrm{C}\right)$ and three holding forces $(25,50$, and $100 \mathrm{psi})$ were used in earlier tests. However, because of the low creep of some of the samples tested, more severe test conditions were chosen to show differences in creep behavior in later tests. Therefore, many tests were operated at $650^{\circ} \mathrm{C}$ and $100 \mathrm{psi}$ later in the program.

The test stands were set up as shown in Figure 28. Each stand has a sensor set up to measure the distance the flag is displaced during the test. This displacement was measured using a Kaman 4-channel measuring system with the following specifications:

- Measuring range: 0.080 inches

- Linearity of 0.004 inches or $1 / 2 \%$ of range

- Resolution of mid-range

- Range expand off 0.001 inches

- Range expand on 0.001 incies

- Sensitivity: $100 \mathrm{mV} / 0.001$ inches

- Full scale voltage: $8000 \mathrm{mV}$

This measuring system used an inductive technique to determine the position of a conductive target relative to the systems sensors. It uses an AC current flowing through the sensor's coil to generate an electromagnetic field that radiates out from the sensor. As a conductive target enters this field, the sensor induces a current flow in it that produces a secondary and opposing field reducing the intensity of the original. This results in an impedance variation in the sensor coil. This coil makes up one leg of a balanced bridge network. As the target changes position within this field, the coil's impedarice also changes. The bridge network senses impedance variations and passes the information to other stages within the signal conditioning electronics for conversion to an analog voltage. This voltage is directly proportional to target displacement. The block diagram in Figure 29 illustrates the system. 


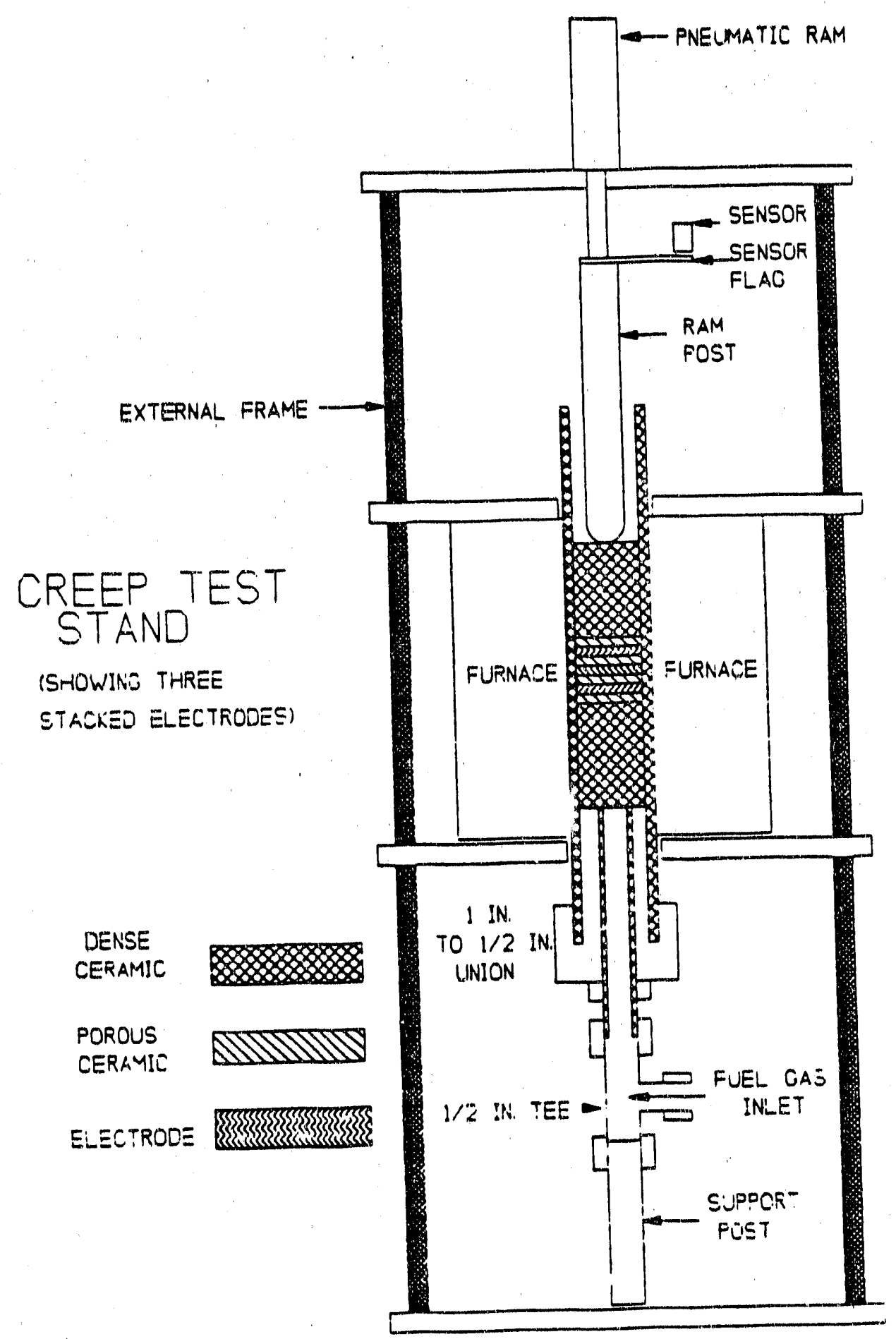

Figure 28. Creep test stand 

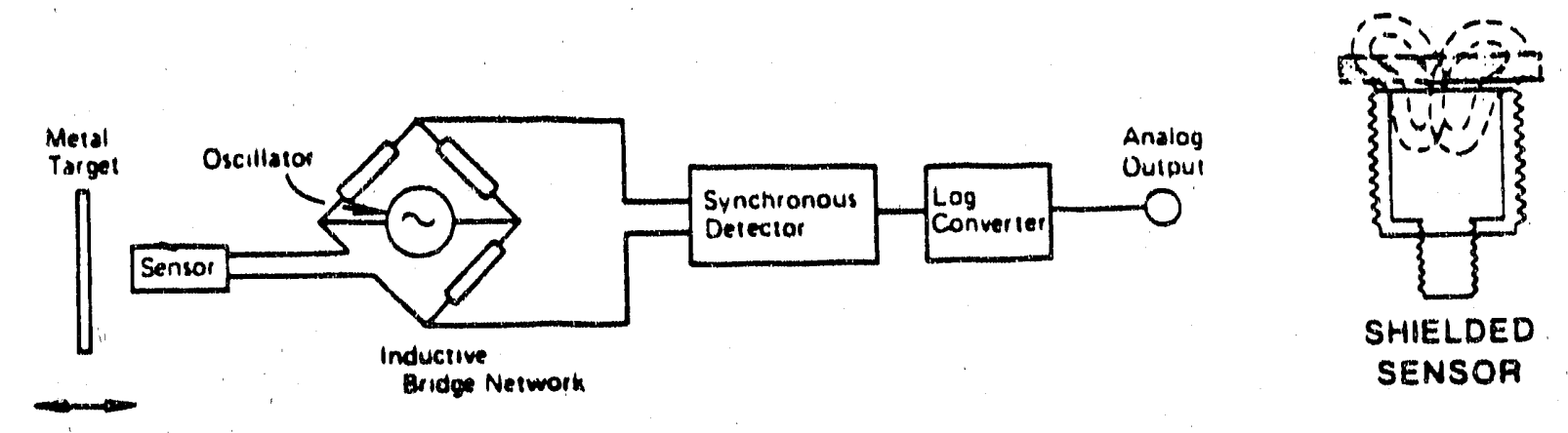

Figure 29. Block diagram of measuring system

The magnitude of the analog output of measuring channel is dependent upon the position of a conductive target perpendicular to the sensor and within the electromagnetic field produced by that sensor. Nonconductive materials intervening between the sensor and target have little or no effect on the system's output. Because of this, environmental contaminants such as oil, dirt, humidity, electrical interference, and magnetic flelds have virtually no effect on system performance.

As stated previously, the specified linear measuring range of the system used was 0.080 inches. This represents the maximum range of given sensor over which the linearity of the system's output can be held to within $\pm .5 \%$. It is not a reference to the maximum depth of the electromagnetic field produced by a given sensor. The actual depth can extend 2 to 3 times beyond the specified linear measuring range (Figure 29). Note that while this systern output will become less linear over this extended range, it can be repeatable.

The data collection and storage was done on an IBM-XT personal computer using an Omega Inc. WB-10-B8 analog interface card.

\subsection{Experimental Procedure}

Samples for testing were very carefully cut using a scalpel and $5 / 8$ in. arch punch using the punch as a cutting guide. The normal procedure (for SOA electrodes) is to use the arch punch and mallet to punch out a circle of electrode. The metal coated anode samples were too fragile and crumbly to punch out, and even after they were cut they were very difficult to handle without breaking.

After the pieces were cut out, the thickness was measured in at least seven places using a micrometer which has a $1 / 8 \mathrm{in}$. diameter tip. The 
measurements were then averaged, the diameter of the piece was measured, and the parts were weighed. Calculations were then done and the density, void volume, sample $\mathrm{Cc}$ solid, and percent porosity were recorded. Finally, an amount of carbonate powder was weighed out based on the calculations to give a $30 \%$ to $40 \%$ fill of carbonate in the porous electrode during testing.

In order to maximize the amount of information from each test, most tests contained three anode samples. Each anode sample was separated from the next by a porous alumina disk as shown in Figure 28. The required carbonate was added during stacking of the anode samples by sprinkling the carbonate onto the porous anode samples. Once the parts were in place, the upper dense ceramic cylinder was placed on top of the test pieces, and the pneumatic ram was bolted to the top of the test rig.

The assembly was heated to $650^{\circ} \mathrm{C}$ in a fuel environment. A high-Biu anode inlet gas consisting of $60 \% \mathrm{H}_{2}$ and $40 \% \mathrm{CO}_{2}$ was humidified at a temperature of $60^{\circ} \mathrm{C}$. The equilibrium composition at $650^{\circ} \mathrm{C}$, considering the shift reaction and ignoring methanation, is $37 \%, \mathrm{H}_{2}, 31 \% \mathrm{H}_{2} \mathrm{O}, 12 \% \mathrm{CO}_{2}$. The next day, the rams were pushed down by hand to contact the samples, since the carbonate soaked into the electrodes and resulted in a change in the vertical height of the assembled pieces. The Kaman sensors were reset at that time to a value of about 10 to 15 mils. Tris was done to keep the sensors in range $(0-80$ mils for the models being used) because with three electrodes in each test height changes as great as 30 mils were observed. Then, a force equivalent to 100 psi (based on the diameter of the test piece) was applied by pressurizing the 1" diameter pneumatic ram with air, sensor tracking was initiated at this point. The tests were run under these conditions for a total of $\sim 168$ hours.

It was noticed that immediately after the pressure was applied, there was marked change in the sensor reading. The sensor readings recorded while releasing the pressure on the pneumatic ram during a test cool-down with no electrodes in the apparatus indicated a vertical displacement of 1 - 3 mils. Based on the initial change and the change at test end, it was decided that the application of the load caused a change in the sensor reading, due to the application of the load force only, and that this change nad nothing to do with the creep behavior of the test specimens. It is believed that the change due to the load is caused by soring-back of the test stand apparatus.

This spring-back is probably why the sensor reading values and the preand post-test measurements do not agree. li was after these spring-back observations were made that it was decided to base the creep values only on the pre- and post-test measurements. The Kaman deter data was used to determine the rate of char.ge in thickness and as an indicator that the test was operating properly.

\subsection{Materials}

Since there were very many variables related $(1)$ the microstructure of the anode plaques, considerable effort was put into characterizing the samples 
before and after they were creep tested. The variables included porosity, mean pore size, pore size distribution, metal loading, metallic composition and ceramic substrate composition. These properties infulence the microstructure including wetting of the ceramic substrate by the metallic phase and the connectivity and contiguity of the metallic phase within the porous sinter.

During the course of the contract, the wetting of the ceramic phase by the metallic phase was improved drastically. Initially, discrete metallic particles larger than the ceramic particles were observed. Both optical microscopy and scanning electron microscopy (SEM) were used to examine polished cross sections of the anode plaques. SEM was utilized to examine fracture surfaces of the compacts to obtain additional information on the degree to which the substrate was wetted.

Initially, it was determined that a uniform metallic coating could be obtained by two separate mechanisms. The preferred method would be to obtain a substrate or a coated substrate which the metallic phase wets with a near zero contact angle. The other method requires that after copious nucleation in which the substrate beconnes populated by discrete metallic particles, the growth of the discrete metallic particles results in their impingement to form a continuous metallic coating (Figure 30 ). This may occur when the contact angle between the metallic phase and the ceramic substrate is greater than zero if sufficient nucleation of metallic particles occurs on the substrate. It requires that the coating thickness be greater than the distance between the nuclei of the metallic particles on the substrate surface.

Porosimetry was used to determine the volume percent porosity, mean pore size, and pore size distribution for each of the anode plaques tested. Initially, the target pore size range was $1-3 \mu \mathrm{m}$. The mean pore sizes of plaques tested in the first part of the contract were typically between $7-15 \mu \mathrm{m}$. Later in the contract, the mean pore size of plaques were reduced and were mostly in the range of $4-10 \mu \mathrm{m}$. The state-of-the-art nickel-10\%chrome anodes are about $65 \mathrm{vol} \%$ porosity and an average pore size of $4.6 \mu \mathrm{m}$. The majority of the metal coated ceramic anodes had 45 to 55 vol \% porosity. In general, the metal coated anodes tested had larger pores and a smaller volume percent porosity than the nickel-chrome anodes presently used at IGT.

Two different ceramic substrates, $\mathrm{LiAlO}_{2}$ and $\mathrm{LiFeO}_{2}$, were used. Stability tests showed that the alpha phase of $\mathrm{LiAlO}_{2}$ was the stable phase in the anode. The alpha phase is known to be more resistant to hydrolization than the gamma phase. The plating trials were performed on gamma phase $\mathrm{LiAlO}_{2}$ powder. A variety of surface modification techniques were attempted to increase the wettability of the substrate by the metallic phase. The $\mathrm{LiFeO}_{2}$ was found to be more readily wetted by the metallic phase. Consequently, most of the work in the latter part of the contract has focused on LiFeO2. Well-wetted sinters were produced by tape casting and sintering the metal-coated $\mathrm{LiFeO}_{2}$ powder. Siability tests indicated that the conversion of $\mathrm{LiFeO}_{2}$ to $\mathrm{LiFe}_{9} \mathrm{O}_{8}$ in the anode environment can occur. Subsequent work at IGT has shown that the 


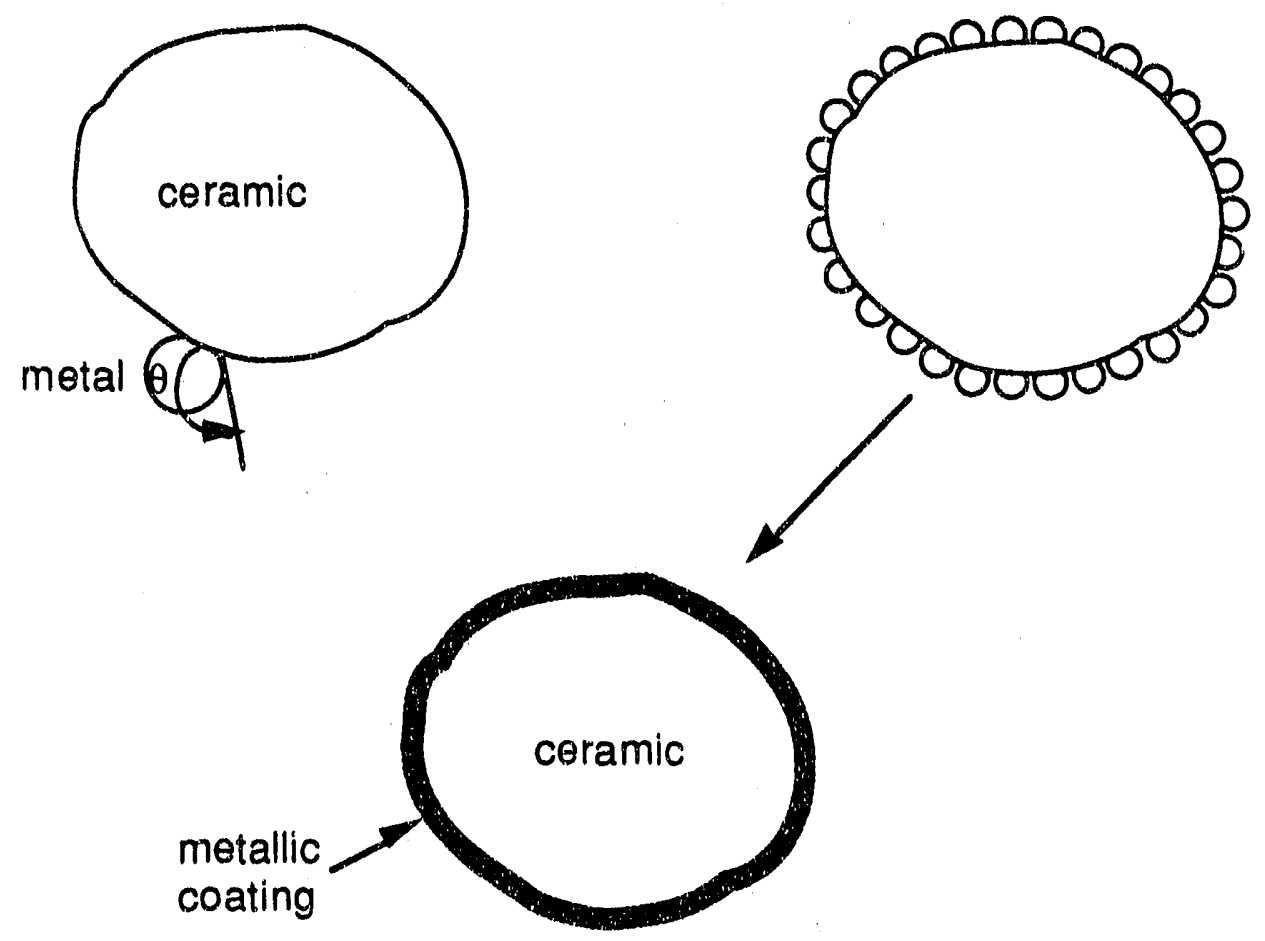

Figure 30 . Schematic of metal particle impingement

stability of $\mathrm{LiFeO}_{2}$ in the anode is sensitive to the fuel gas composition and the potential on the anode in an operating cell.

Chernical analysis was performed to determine the metal-to-ceramic ratio of the anode materials. The anodes tested were coated with pure nickel or a nickel-copper alloy. The nickel-copper coatings were generally about $50 \mathrm{wt} \%$ each metal. The amount of metal in the samples or metal loading varied between 10 and $60 \mathrm{wi} \%$

Scanning electron photomicrographs of polished cross-sections of the anode plaques before testing showed that as the contract progressed, the quality of the materials produced was consistently improved until the target microstructure was obtained. This idealized microstructure is shown in Figure 1. Photomicrographs showing the degree to which the ability to engineer this idealized microstructure was improved are shown in Figure 31.

During the course of the contract, metal-coated anode plaques with additions of either chrome or aluminum were tested. The additions of these readily oxidized metals to the metallic coatings were made to improve the creep by inhibiting dewetting and preventing coarsening of the metallic phase. The addition of either chrome or aluminum is known to retard the sintering of stateof-the-art nickel-chrome anodes by inhibiting surface-driven phenomena. 

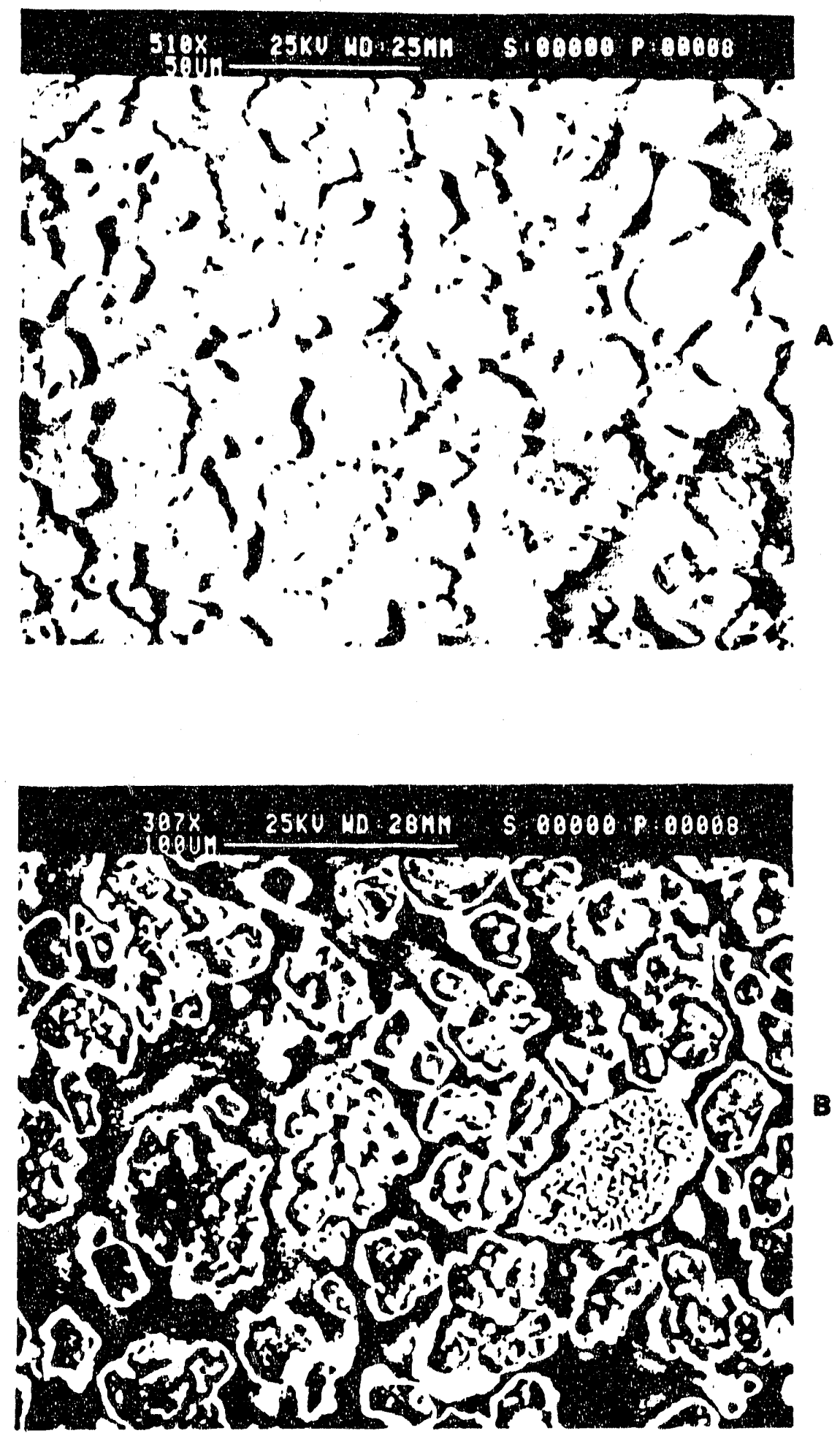

Figure 31. Micrographs of metal coated anodes

(The micrographs show the improvement in engineered metal-coated ceramic microstructure over the course of the contract. As-received anodes from batch 3 (figure A) and batch 8 (figure B) are shown. - metallic phase appears lighter). 


\subsection{Results of Out-of-Cell Creep Tests}

A total of 123 electrode plaques were creep tested during the 2-year period of this report. The breakdown of materials, number of pieces tested, and test conditions are as follows:

\begin{tabular}{|c|c|c|}
\hline $\mathrm{LIAlO}_{2}$ & $\mathrm{LIFeO}_{2}$ & $\mathrm{Ni} \cdot \mathrm{Cr}$ \\
\hline $650^{\circ} \mathrm{C}, 25 \mathrm{psi}$ & $650^{\circ} \mathrm{C}, 25 \mathrm{psi}$ & $650^{\circ} \mathrm{C}, 25 \mathrm{psi}$ \\
0 pieces & 0 pieces & 1 piece \\
\hline $650^{\circ} \mathrm{C}, 50 \mathrm{psi}$ & $650^{\circ} \mathrm{C}, 50 \mathrm{psi}$ & $650^{\circ} \mathrm{C}, 50 \mathrm{psi}$ \\
11 pieces & 0 pieces & 2 pieces \\
\hline $650^{\circ} \mathrm{C}, 100 \mathrm{psi}$ & $650^{\circ} \mathrm{C}, 100 \mathrm{psi}$ & $650^{\circ} \mathrm{C}, 100 \mathrm{psi}$ \\
53 pieces & 23 pieces & 16 pieces \\
\hline $700^{\circ} \mathrm{C}, 25 \mathrm{psi}$ & $700^{\circ} \mathrm{C}, 25 \mathrm{psi}$ & $700^{\circ} \mathrm{C}, 25 \mathrm{psi}$ \\
0 pieces & 0 pieces & 0 pieces \\
\hline $700^{\circ} \mathrm{C}, 50 \mathrm{psi}$ & $700^{\circ} \mathrm{C}, 50 \mathrm{psi}$ & $700^{\circ} \mathrm{C}, 50 \mathrm{psi}$ \\
8 pieces & 0 pieces & 0 pieces \\
\hline $700^{\circ} \mathrm{C}, 100 \mathrm{psi}$ & $700^{\circ} \mathrm{C}, 100 \mathrm{psi}$ & $700^{\circ} \mathrm{C}, 100 \mathrm{psi}$ \\
9 pieces & 0 pieces & 0 pieces \\
\hline
\end{tabular}

There was much scatter to the results. Of all the tests, the SOA Ni-Cr electrodes showed the least creep. The creep ranged from a low of $0.65 \%$ to a high of $6.18 \%$ and were the most consistent. The $\mathrm{LiAlO}_{2}$ electrodes creep values ranged from a low of $0.96 \%$ to a high of $20.23 \%$. The $\mathrm{LiFeO}_{2}$ electrodes had the most scatter and creep ranged from a low of $1.46 \%$ to a high of 33.93 . A few tests showed a creep value of $0 \%$. From the experience gained on the other tests, a value of $0 \%$ is not possible. These tests should not be used for anlaysis of the test matrix.

A summary of all creep test results are shown in Table 14. The Kaman meter readings, creep as a function of time, are plotted for selected creep tests in Figures 32-37. 
Table 14. Summary of Creep Test Results

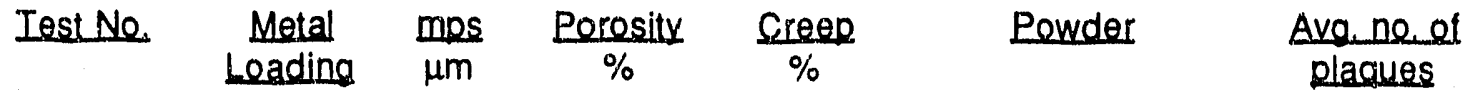

$\mathrm{LiAlO}_{2}$ at $650^{\circ} \mathrm{C}$ and $100 \mathrm{psi}$

2.3.1b-01

2.3.1b-01

2.3.1b-03

2.3.1b-04

2.3.1b-06

2.3.1b-07

2.3.1b-08

2.3.1b-09

2.3.1b-09

2.3.1b-09

2.3.1B-12

2.3.1B-13

2.3.1B-14

$$
44.74
$$

44.32

48.2

51.07

34.4

51.35

39.5

50.0

50.0

50.0

10.1

50.0

34.0
$10.5 \quad 50.1$

9.5

7.4

15.0

8.0

16.5

7.0

N/A

$N / A$

N/A

N/A

N/A

N/A

\section{6}

49.7

54.5

43.1

51.89

46.11

55.81

55.55

56.71

51.15

58.85

54.61

\subsection{2}

8.47

7.7

20.23

3.17

10.68

5.25

12.08

10.79

8.14

2.06

20.69

2.77

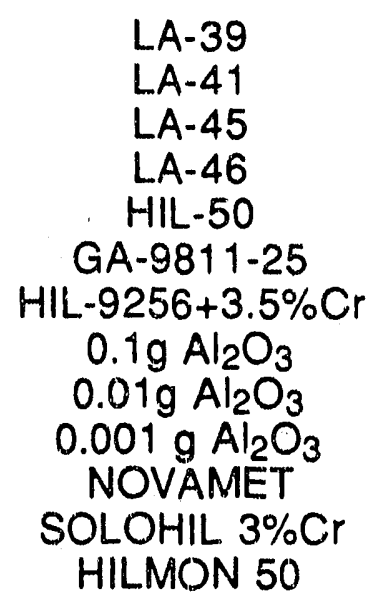

HILMON 50

$\mathrm{LiAlO}_{2}$ at $650^{\circ} \mathrm{C}$ and $50 \mathrm{psi}$

2.3.1b-02

2.3.1b-03

2.3.1b-04

2.3.1b-07
44.32

42.32

51.07

52.35
9.5

7.4

15.0

16.5
50.8

49.7

54.5

51.89
3.96

6.06

11.56

9.44

\begin{abstract}
LA-41
LA MIX

LA-46
\end{abstract}

GA-9811-25
4
3
2
3
1
3
6
3
3
3
8
6
8

$\mathrm{LiAlQ}_{2}$ at $700^{\circ} \mathrm{C}$ and $50 \mathrm{psi}$

2.3.1b-02

2.3.1b-03

2.3.1b-04
44.32 48.2 51.07
9.5

8.45 15.0

\section{8}

49.7

54.5
1.54

6.33

13.52
LA- 41
LA- 45
LA- 46

3
2
3
3

$\mathrm{LiAlO}_{2}$ at $700^{\circ} \mathrm{C}$ and $100 \mathrm{psi}$

2.3.1b-07

2.3.1b-02

2.3.1b-07

2.3.1b-08
51.35

44.32

51.35

39.50
16.5
9.5
16.5
7.0

$\begin{array}{cc}59.08 & 15.95 \\ 50.8 & 12.03 \\ 51.89 & 12.46 \\ 46.11 & 3.0\end{array}$

$\begin{array}{cc}\text { GA- } 9811-25 & 1 \\ \text { LA-41 } & 3 \\ \text { GA-9811-25 } & 2 \\ \text { HIL- } 9256+3.5 \mathrm{Cr} & 3\end{array}$

$\mathrm{LiFe} \mathrm{O}_{2}$ at $650^{\circ} \mathrm{C}$ and $100 \mathrm{osi}$ 2.3.1b-10

2.3.1b-05

2.3.1b-05

2.3.1b-06

2.3.1b-06

2.3.1b-11

2.3.1b-11
50.49

37.0

37.0

37.0

46.5

43.33

66.0
$9.0 \quad 27.63$

6.0

6.0

48.7

43.42

7.11

4.31

6.0

44.10

1.45

2.55

6.0

43.8

N/A

$N / A$
40.97

43.07
6.31

32.12

32.20
LF -18

LF-10

LF-10

LF-10

LF-9

LF -19

LF-16
3
2
3 


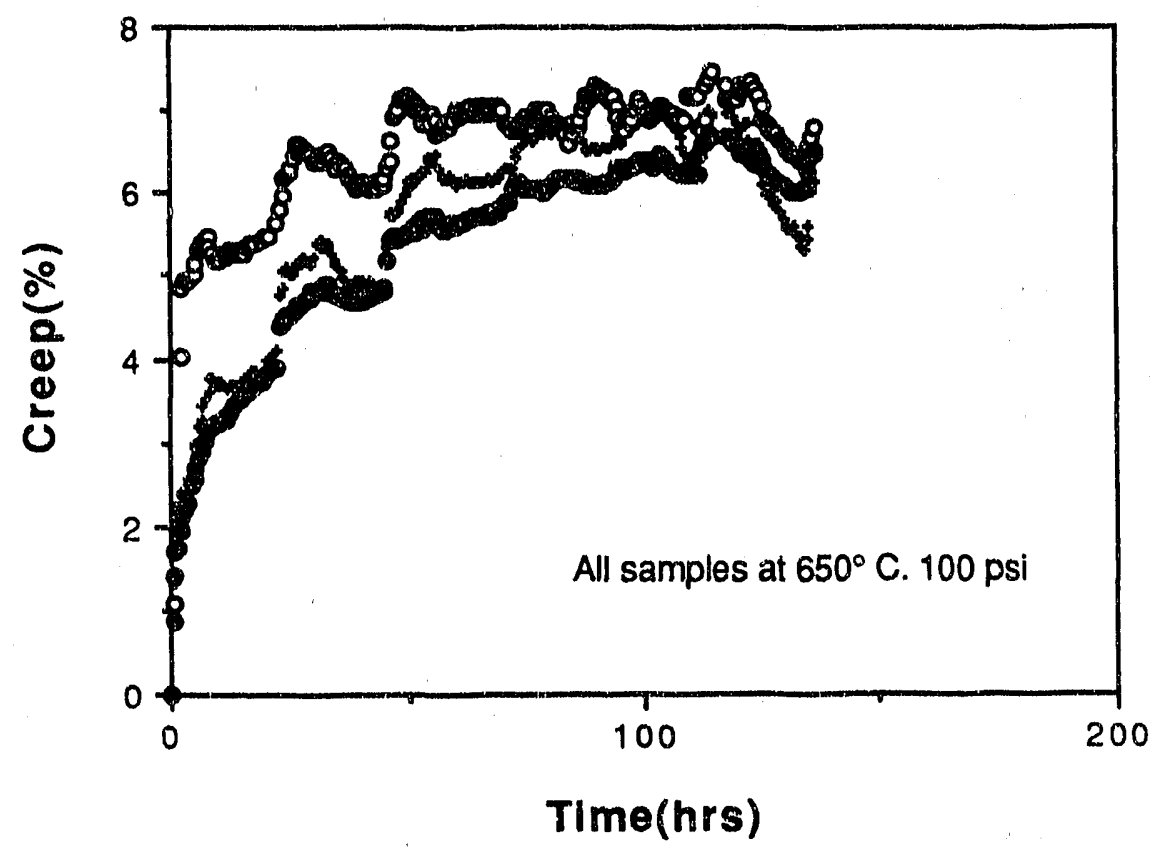

Figure 32. Creep test 2.3.1b-01 (electroless plated $\mathrm{LiAlO}_{2}$ )

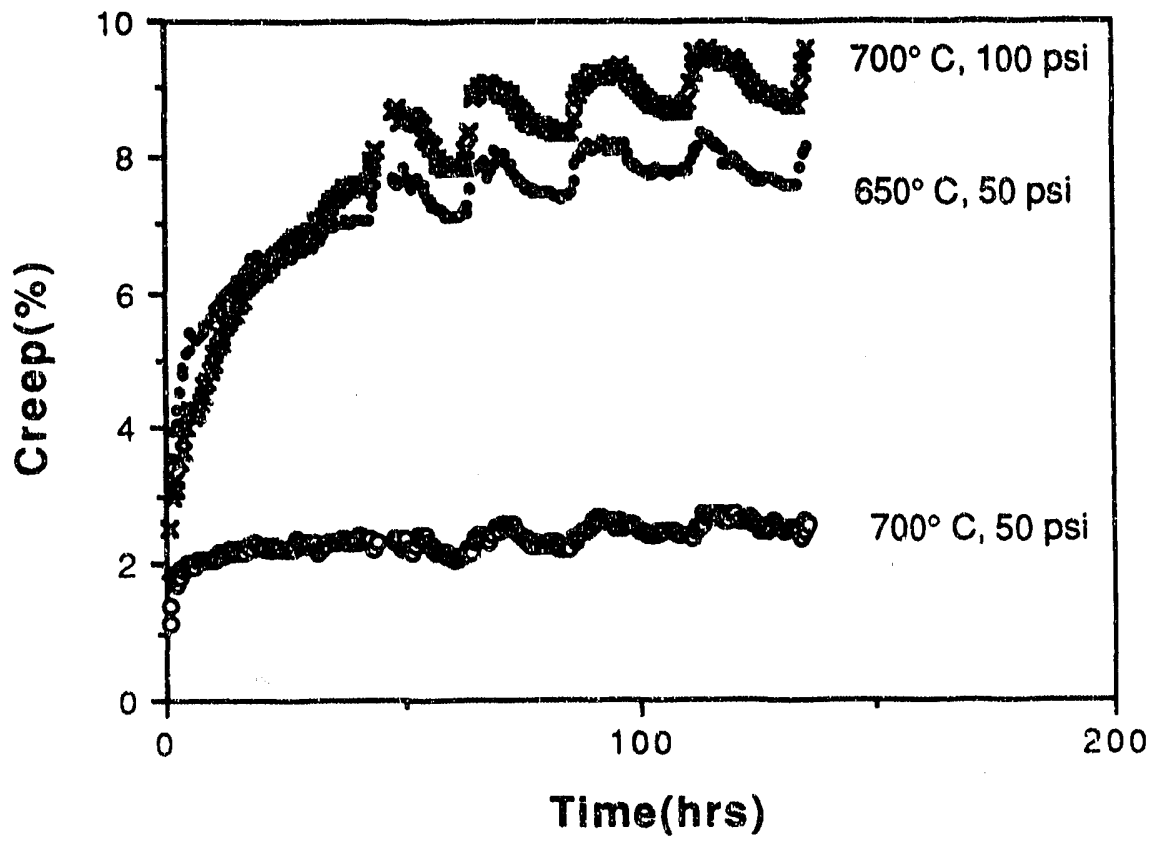

Figure 33. Creep test 2.3.1b-02 (electroless plated $\mathrm{LiAlO}_{2}$ ) 


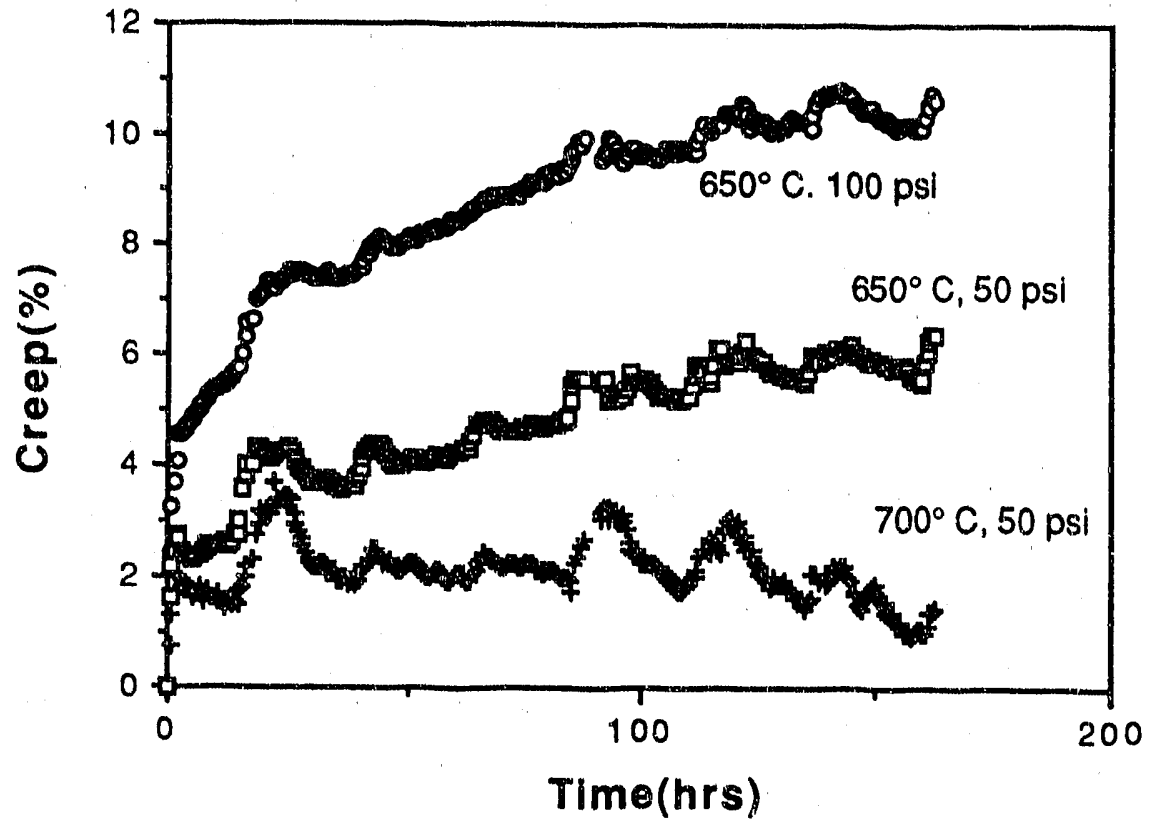

Figure 34. Creep test 2.3.1b-03 (electroless plated $\mathrm{LiAlO}_{2}$ )

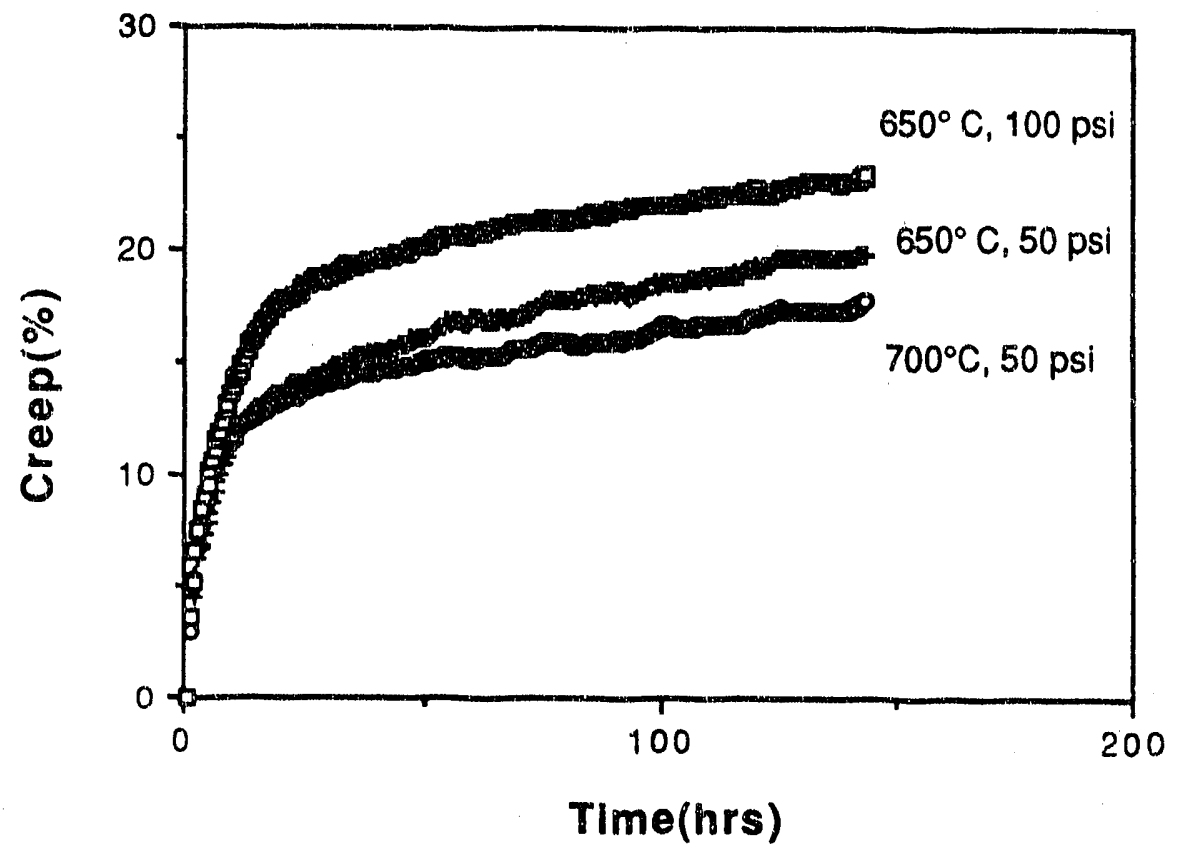

Figure 35. Creep test 2.3.1b-04 (electroless plated $\mathrm{LiAlO}_{2}$ ) 


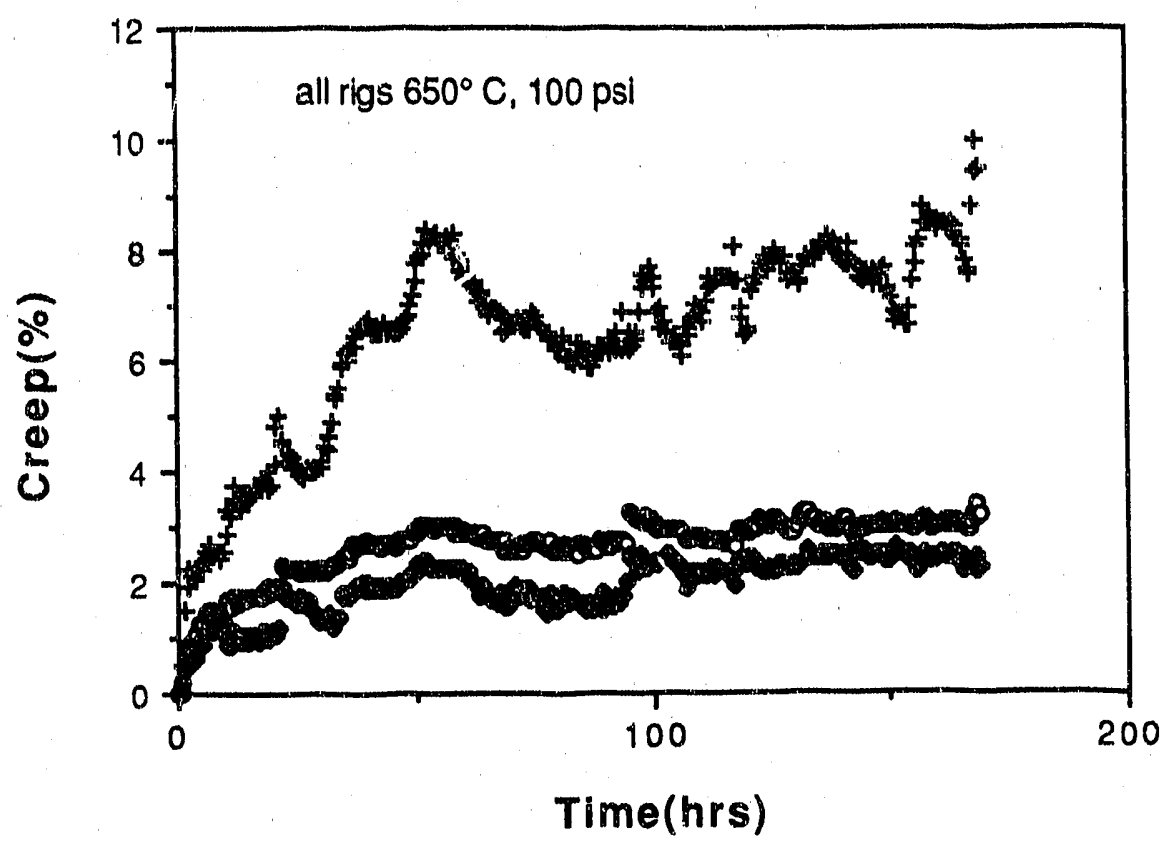

Figure 36. Creep test 2.3.1b-14 (CVD LiAlO 2 - Hilmon 50)

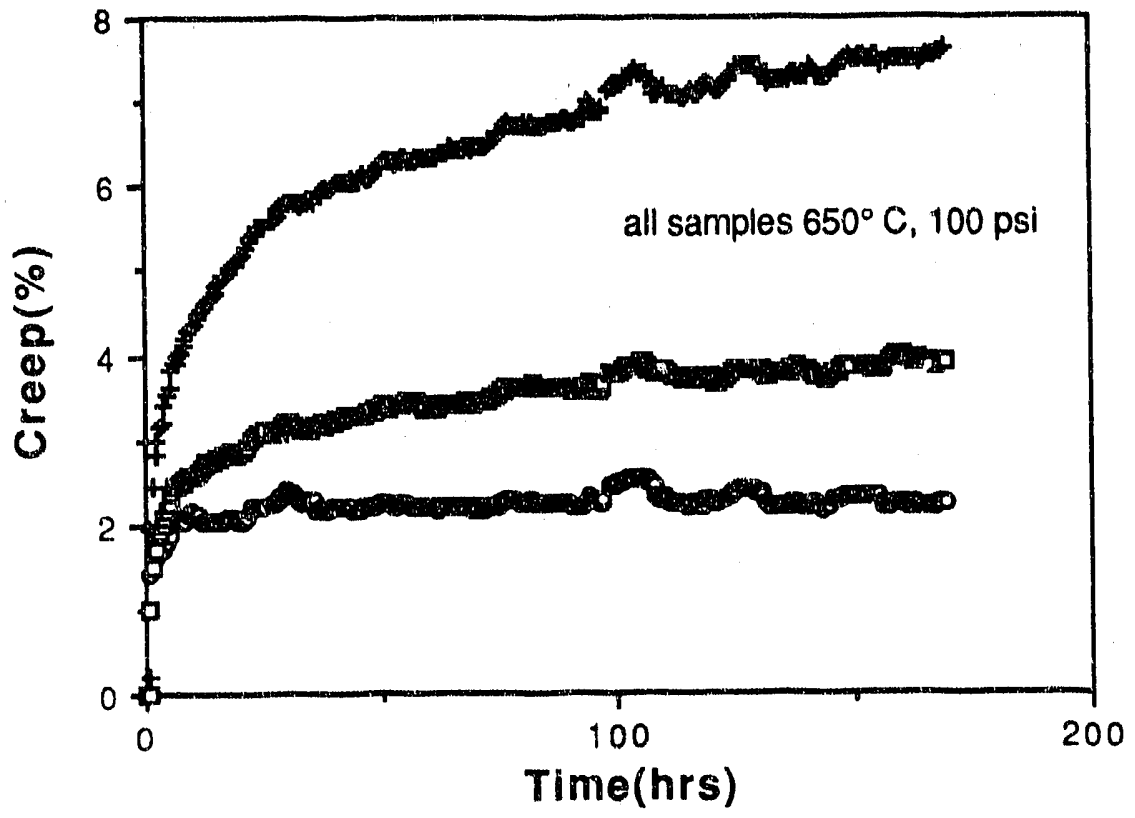

Figure 37. Creep test 2.3.1b-05 (electroless plated $\mathrm{LiFeO}_{2}$ ) 


\subsection{IN-CELL TESTING}

\subsection{Introduction}

An in-cell test was made using standard boiler-plate hardware, a $\mathrm{LiF}_{\theta} \mathrm{O}_{2}$ anode made by Ceramatec and sintered at IGT, SOA Ni cathode, stainless steel cathode current collector, and a $\mathrm{Ni}$ anode current collector. The cell package was assembled and then placed in the bench-scale test stand. A diagram of how the cell package is set up in the test stand is shown in Figure 38.

\subsection{Anode Test In-Cell}

Three nickel coated $\mathrm{LiAlO}_{2}$ tapes and one nickel coated $\mathrm{LiFeO}_{2}$ tape size large enough to test in bench-scale $\left(94 \mathrm{~cm}^{2}\right.$ ) (Batch LF-18, Part No. 3708, 54\% metal loading) were sent to IGT for sintering and for creep and bench-scale fuel cell tests. At the time they were received at IGT, their muffle furnace was under repair and sintering of the components were being done at outside vendor facilities. An attempt was made to sinter a $\mathrm{Ni} / \mathrm{LiAlO} 2$ in a continuous furnace purged with cracked ammonia gas $\left(75 \% \mathrm{H}_{2} / 25 \% \mathrm{~N}_{2}\right.$ having a dew point of $\sim-20^{\circ} \mathrm{C}$, a common purge gas for industrial sintering of powder metals). The sample, however, became jammed inside the furnace and was not recovered. A second $\mathrm{Ni} / \mathrm{LiAlO}_{2}$ tape and the $\mathrm{Ni} / \mathrm{LiFeO} 2$ tape were then sintered in a standard muffle furnace, also purged with cracked ammonia gas. The heating schedule followed was:

4 hours ramped to $850^{\circ} \mathrm{C}$

1 hour ramp to $950^{\circ} \mathrm{C}$

15 minute hold at $950^{\circ} \mathrm{C}$

Cool.

The $\mathrm{Ni} / \mathrm{LiFeO}_{2}$ tape sintered into a handleable component but the $\mathrm{Ni} / \mathrm{LiAlO} 2$ rubbed to a loose powder.

The third $\mathrm{Ni} / \mathrm{LiAlO} 2$ tape was sintered at IGT after the repair of the muffle furnace. The purge gas $10 \mathrm{H}_{2} / 90 \mathrm{~N}_{2}$ and the heating schedule was similar to that given above. Again, the heat treated tape was powdery. But since it was in one piece without cracks, it was reheated at the highest temperature capability of the muffle furnace.

The schedule was -

5 hours ramp to $1050^{\circ} \mathrm{C}$

30 minute hold at $1050^{\circ} \mathrm{C}$

cool.

The structure still did not sinter and it broke into weak fragments. Therefore, only the $\mathrm{Ni} / \mathrm{LiFeO}$ became available for testing. 


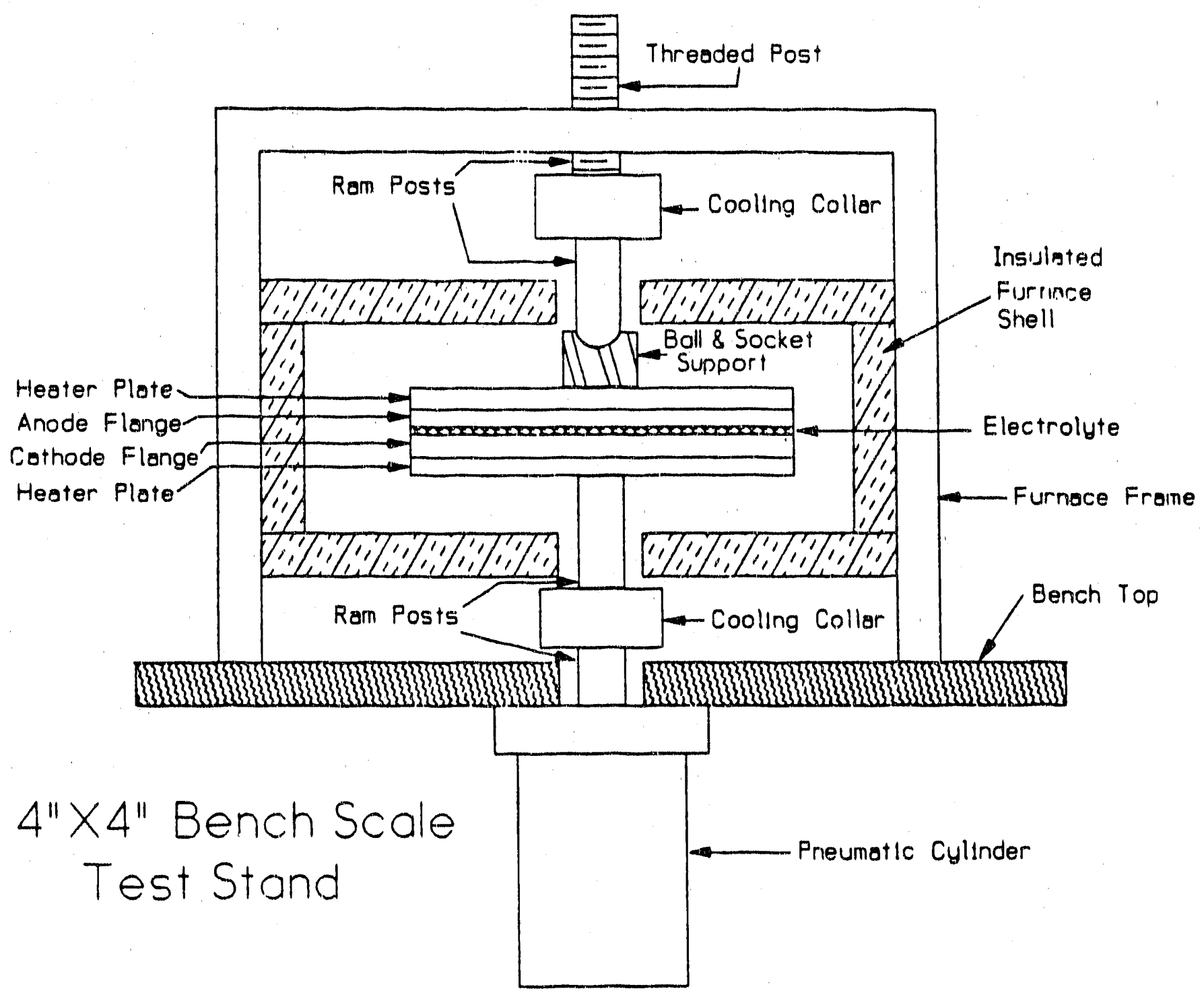

Figure 38. Schematic of bench-scale test stand 
The $\mathrm{LiFeO}_{2}$ electrode was from powder Batch LF-18, which had $54 \%$ metal loading. Its thickness varied from 0.0233 inch to 0.0064 inch, and was cut to fit the flange. Some points on the edges were as thin as 0.0128 inch. Since this did not meet the required thickness of 0.030 inch, the anode flange had to be remachined to fit. The thickness variation also was not to specs of \pm 0.001 inch and this may have caused poor contact in some areas. The cell package was assembled using a state-of-the-art (SOA) nickel cathode and hot-pressed tile from the SD60-3Z5 batch. The test was designated CERLIFe-1 and was begun using a normal slow ramp heat-up (room temperature to $350^{\circ} \mathrm{C}$ in 3 hours, from $350^{\circ} \mathrm{C}$ to $650^{\circ} \mathrm{C}$ in 18 hours). The initial cell performance was poor compared to a SOA cell; it would not hold a stable voltage at $140 \mathrm{~mA} / \mathrm{cm}^{2}$ load, and the resistance was somewhat high at $7.68 \mathrm{~m} \Omega$. Increases in the cell holding force which was at 10 psi initially were applied at 24 (15 psi), 143 (20 psi), 167 (25 psi), 191 (30 psi), and 239 (35 psi) hours. The reason for increasing the holding force was to attempt to improve the contact of the anode to the tile in case the resistance, and poor performance, were due to poor surface contact between the anode and electrolyte. (The poor contact may have been due to the thickness variation of the electrode.) A table showing the cell performance $\mathrm{mV}$, IR-free $\mathrm{mV}$, and polarization $\mathrm{mV}$ is shown in Table 15. A graph showing $\mathrm{mV}$ at various load settings versus time is shown in Figure 39.

Some attempts to pinpoint the reasons for the poor performance were made by using pure $\mathrm{H}_{2}$ and normal oxidant $\left(30 \% \mathrm{CO}_{2}+\right.$ balance air), regular fuel $\left(60 \% \mathrm{H}_{2}+40 \% \mathrm{CO}_{2}\right)$ and rich oxidant $\left(66 \% \mathrm{CO}_{2}+33 \% \mathrm{O}_{2}\right)$, a richer fuel $\left(75 \% \mathrm{H}_{2}+25 \% \mathrm{CO}_{2}\right)$ and with normal oxidant $\left(30 \% \mathrm{CO}_{2}+\right.$ balance air). The results of these attempts were compared with normal fuel and oxidant that was used throughout the cell test fuel $=\left(60 \% \mathrm{H}_{2}+40 \% \mathrm{CO}_{2}\right)$, and oxidant $=(30 \%$ $\mathrm{CO}_{2}$ + balance air). A comparison of the IR loss $\mathrm{mV}$, IR-free $\mathrm{mV}$, and the polarization at a $160 \mathrm{~mA} / \mathrm{cm}^{2}$ load setting is shown in Table 16.

The cell was terminated after 360 hours of cell life, since little improvement was observed after the last cell holding force increase. The terminated anode and current collector were measured and compared to the pre-test anode measurements. Allowing for the thickness of the current collector, which was subtracted from the total measurement since it could not be separated from the anode, the change in anode thickness from pre-test to posttest was 2.6 mils. This change, based on the pre-test thickness of 19.7 mils, corresponds to a $13.2 \%$ creep value for the anode.

\subsection{Cenclusion}

As can be seen from Figure 39 and Table 16, the performance of this cell was inferior to SOA performance. From Table 16 it can be seen that the OCV of cell CERLiFe-1 was acceptable indicating the proper electrochemical potentials each side of the cell (no gas crossover). This was corroborated by measuring the gas crossover during cell life. However, looking at the cell potential at 160 $\mathrm{mA} / \mathrm{cm}^{2}$ and 192 hours, it can be seen that it is about $377 \mathrm{mV}(758-381)$ lower 
Table 15. Cell Test CERLiFe-1 Life Data

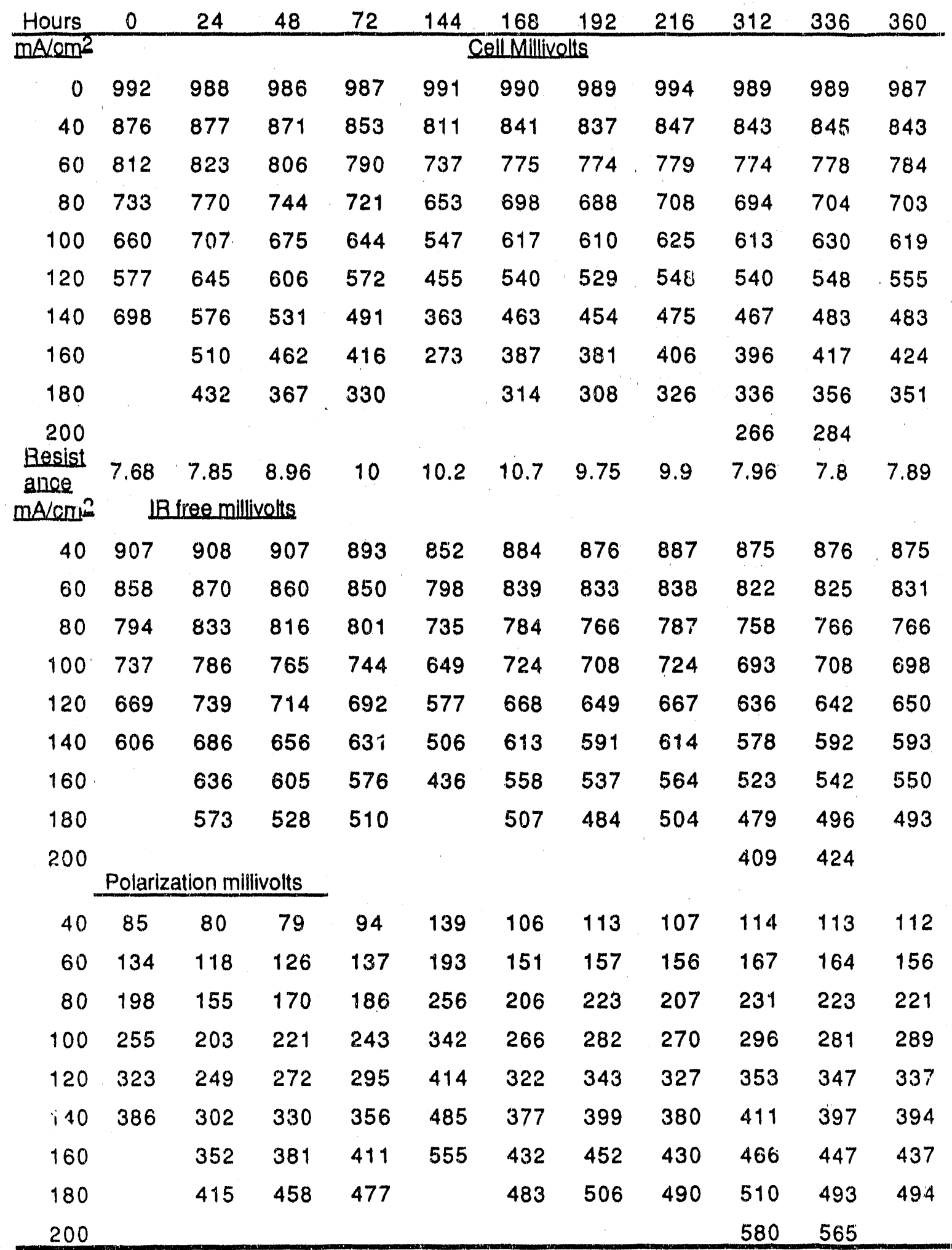

TA FREE $m V=m V$ load plus resistance in milli-ohms times amps at load setting

i.e., 7.68 milli-ohms times $\left(\left(100 \mathrm{~cm}^{2} \times 160 \mathrm{mAcm}^{2}=16000 \mathrm{~mA}\right) / 1000\right)=122.88 \mathrm{mV}$

Polarization voltage equals OCV millivolts minus $I R$ free millivolts 


$$
\begin{aligned}
& +00 \\
& \text { - 40ma/em } \\
& 0 \text { ocons/and } \\
& \text { - 00ma/ang } \\
& \text { - tooma/arne } \\
& \text { Q seomadaral } \\
& \text { - 180ma/ani } \\
& \text { - 1000n/rans } \\
& \text { a 100and/ans }
\end{aligned}
$$

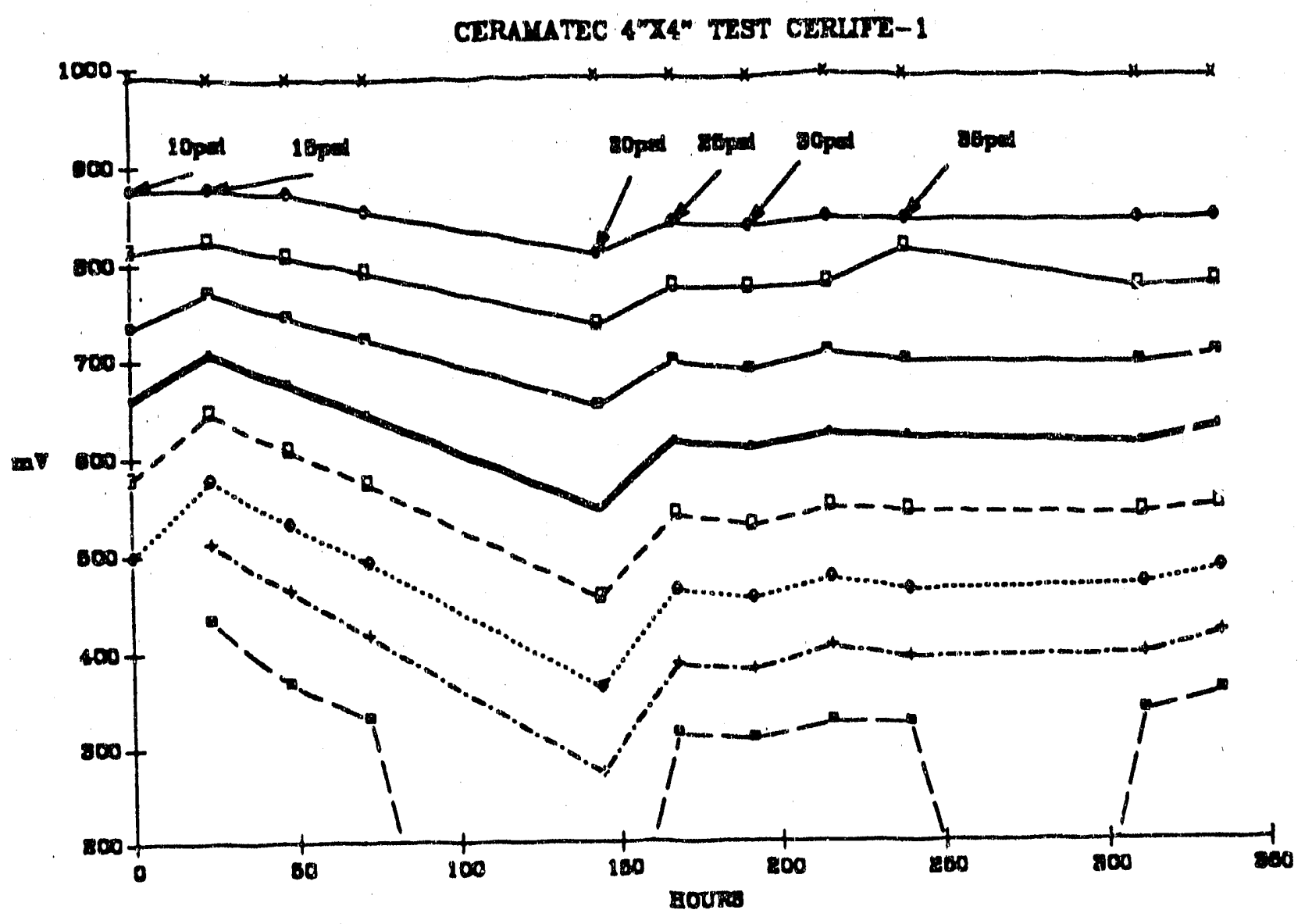

Figure 39 Cell test CerLiFe-1 - Cell voltage at various load settings 
Table 16. Comparison of IR Loss, IR-Free, and Ploarization

Cell Test CERLiFe-1

\begin{tabular}{cccccccc} 
Hours & OCV & $\begin{array}{c}\mathrm{mV} \text { at 100 } \\
\mathrm{mA} / \mathrm{cm}^{2}\end{array}$ & $\begin{array}{c}\mathrm{mV} \text { at } 160 \\
\mathrm{~mA} / \mathrm{cm}^{2}\end{array}$ & $\begin{array}{c}\text { IR loss at } \\
160 \mathrm{~mA} / \mathrm{cm}^{2}\end{array}$ & $\begin{array}{c}\text { IR free at } \\
160 \mathrm{~mA} / \mathrm{cm}^{2}\end{array}$ & $\begin{array}{c}\text { Resistance } \\
\mathrm{m} \Omega\end{array}$ & $\begin{array}{c}\text { Polarization } \\
\text { at } 160 \\
\mathrm{~mA} / \mathrm{cm}^{2}\end{array}$ \\
\hline 0 & 992 & 660 & N/A & 123 & N/A & 7.7 & N/A \\
24 & 988 & 707 & 510 & 125 & 635 & 7.8 & 353 \\
48 & 986 & 675 & 462 & 142 & 604 & 8.9 & 382 \\
72 & 987 & 644 & 416 & 160 & 576 & 10 & 411 \\
144 & 991 & 547 & 273 & 163 & 436 & 10.2 & 555 \\
168 & 990 & 617 & 387 & 171 & 558 & 10.7 & 432 \\
132 & 989 & 610 & 381 & 155 & 536 & 9.7 & 453 \\
216 & 994 & 625 & 406 & 158 & 564 & 9.9 & 430 \\
240 & 991 & 621 & 394 & 139 & 533 & 8.7 & 458 \\
312 & 989 & 613 & 396 & 127 & 523 & 7.96 & 466 \\
336 & 989 & 630 & 417 & 125 & 542 & 7.8 & 447 \\
360 & 987 & 619 & 424 & 126 & 550 & 7.89 & 437 \\
\hline
\end{tabular}

Data from a normal S ) A fuel cell with $\mathrm{Ni}+\mathrm{Cr}$ Anode (Cell Test IGT-83-5AC):

\begin{tabular}{llllllll}
192 & 991 & 847 & 758 & 85 & 843 & 5.32 & 148 \\
\hline
\end{tabular}

than the SOA cell test IGT-83-5AC shown in Figure 40 (just the first 360 hours of a 528 hour test ate shown for comparison). This $377 \mathrm{mV}$ lower performance is made up from $70 \mathrm{mV}$ higher IR (155 - 85) and $305 \mathrm{mV}$ higher polarization loss $(453-148)$. That is, most of the observed lower performance is due to polarizatiun losses which are most likely due to the active three phase contact on this metal coated $\mathrm{LiFeO}_{2}$ anode not being optimized in this first test. This factor is encouraging since the particle size and the electrode morphology can be developed to more closely match that of a SOA electrode.

The pre-test sample was analyzed for $\mathrm{Ni}, \mathrm{Cu}, \mathrm{Fe}$ and $\mathrm{Li}$ by atomic absorption of a completely dissolved anode solution. The percentages of $\mathrm{Fe}$ and $\mathrm{Li}$ in the samples were converted to percentages of $\mathrm{Fe}_{2} \mathrm{O}_{3}$ and $\mathrm{Li}_{2} \mathrm{O}$, which may be combined to represent $\mathrm{LiFeO}_{2}$ or $\mathrm{Li}_{x} \mathrm{FeO}_{2}$ in case of non-stoichiometry.

Results of chemical analysis of pre- and post-test anode are presented in Table 17. The pre-test sample consisted of $\mathrm{Cu}, \mathrm{Ni}$ and $\mathrm{LiFeO}_{2}$. The Li-to- $\mathrm{Fe}$ atom ratio was 0.36 , indicating a Li-deficient lithium iron oxide compound which can be represented as $\left(\mathrm{Li}_{2} \mathrm{O}\right)_{x} \mathrm{Fe}_{2} \mathrm{O}_{3}$ with $\mathrm{x}=0.36$.

The post-test anode contained $\mathrm{Li}_{2} \mathrm{CO}_{3}$ and $\mathrm{K}_{2} \mathrm{CO}_{3}$. To breaksown the total $\mathrm{Li}$ to those tied up to $\left(\mathrm{Li}_{2} \mathrm{O}\right)_{x} \mathrm{Fe}_{2} \mathrm{O}_{3}$ and $\mathrm{Li}_{2} \mathrm{CO}_{3}, \mathrm{CO}_{2}$ analysis was 


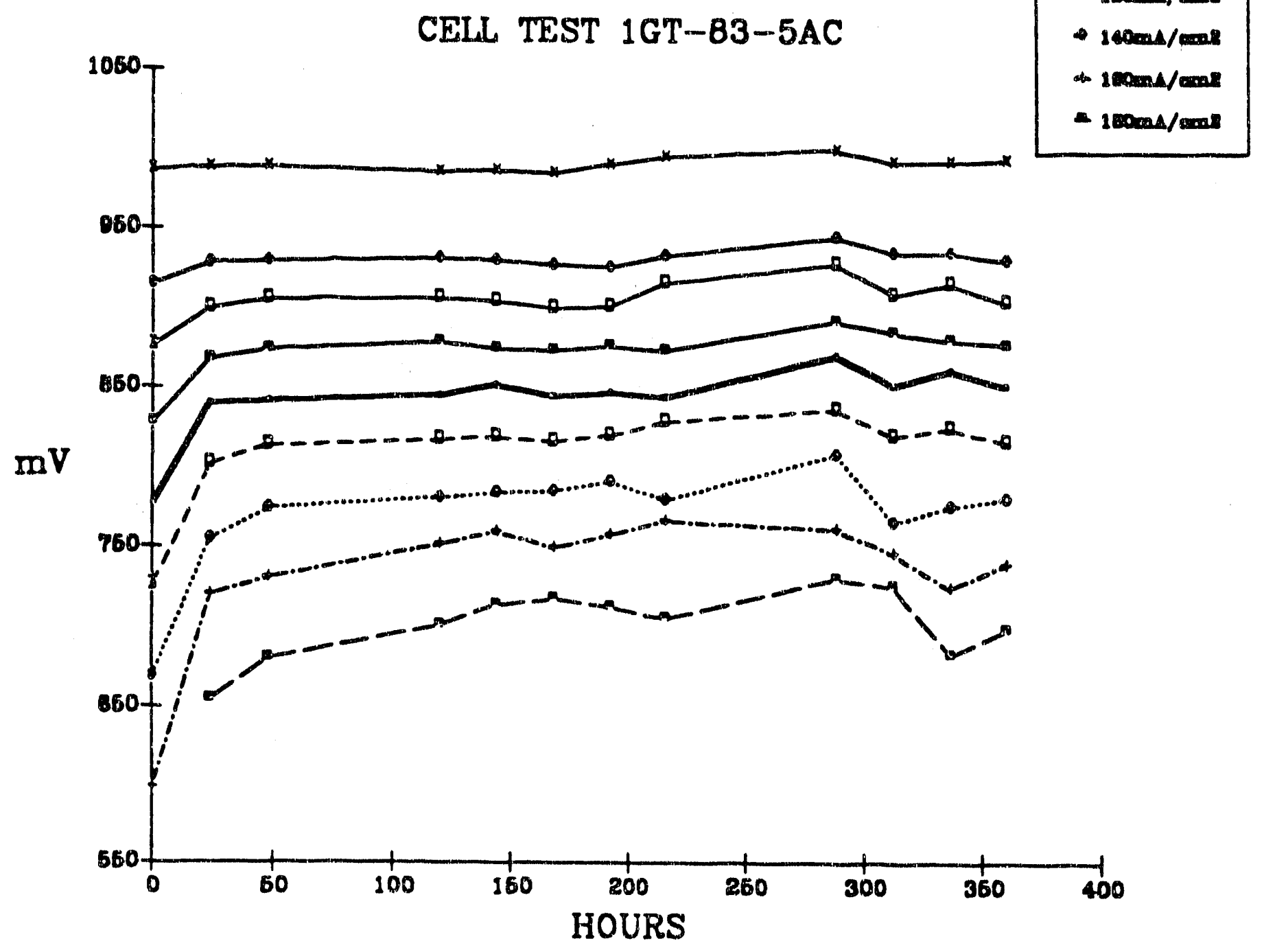

Figure 40. SOA cell test - Cell voltage at various load settings 
Table 17. Chemical Analysis

\begin{tabular}{|c|c|c|}
\hline Components & Pre-test & Post-test \\
\hline $\mathrm{Cu}$ & 40.84 & 35.63 \\
\hline $\mathrm{Ni}$ & 25.60 & 22.32 \\
\hline $\mathrm{Li}$ & 1.20 & 1.88 \\
\hline $\mathrm{Fe}$ & 26.61 & 20.50 \\
\hline $\mathrm{K}$ & -- & 2.23 \\
\hline $\mathrm{CO}_{2}$ & -- & 3.40 \\
\hline \multicolumn{3}{|c|}{} \\
\hline $\mathrm{Li}_{2} \mathrm{O}$ & 2.57 & 3.72 \\
\hline $\mathrm{Fe}_{2} \mathrm{O}_{3}$ & 38.04 & 29.34 \\
\hline $\mathrm{K}_{2} \mathrm{CO}_{3}$ & & 3.94 \\
\hline $\mathrm{Li}_{2} \mathrm{CO}_{3}$ & & 0.75 \\
\hline \multicolumn{3}{|c|}{} \\
\hline $\mathrm{Li}_{2}: \mathrm{Fe}_{2} \mathrm{O}_{3}$ (bymole $)$ & 0.36 & 0.68 \\
\hline $\mathrm{Cu}: \mathrm{Ni}$ (by weight) & 1.60 & 1.60 \\
\hline $\mathrm{Metal}: \mathrm{Fe} \mathrm{O}_{2} \mathrm{O}_{3}(\mathrm{by}$ & 1.75 & 1.98 \\
weight) & & \\
\hline
\end{tabular}

performed. Thus, it was assumed that $\mathrm{K}$ was converted to $\mathrm{K}_{2} \mathrm{CO}_{3}$ and $\mathrm{CO}_{2}$ in excess of that tied up to $\mathrm{K}$ was combined with $\mathrm{Li}$ to form $\mathrm{Li}_{2} \mathrm{CO}_{3}$. Excess $\mathrm{Li}$ not tied up with $\mathrm{CO}_{2}$ was then assumed to be tied up with $\mathrm{Fe}$ in the form of $\left(\mathrm{Li} \mathrm{O}_{\mathrm{X}} \mathrm{Fe}_{2} \mathrm{O}_{3}\right.$. The results yield an $\mathrm{x}=0.68$ post-test. Therefore, lithiation of the anode took place during cell operation. This is not surprising since one would expect the stoichiometric $\mathrm{Li}_{2} \mathrm{O} . \mathrm{Fe}_{2} \mathrm{O}_{3}$ to be stable phase in the presence of electrolyte. In fact, one should start with an stoichiometric $\mathrm{LiFeO}_{2}$ material to prevent Lithium consumption from the elecrolyte.

The $\mathrm{Cu} / \mathrm{Ni}$ ratio was similar for both pre- and post-test samples as expected for a sample coated under controlled conditions.

The metal-to- $\mathrm{Fe}_{2} \mathrm{O}_{3}$ ratio was 1.75 pre-test and 1.98 post-test suggesting slight non-uniformity in metal loading throughout the sample.

The carbonate content of the post-test anode was only $4.69 \%$ by weight or $25 \%$ filling of the $41 \%$ anode porosity. This carbonate content is generally acceptable. 


\subsection{ANALYSIS OF POWDER COATING AND CREEP RESULTS}

\subsection{Introduction}

The results obtained on powder plating have been summarized in the individual sections earlier in this report. In this section, general comments on the merits and demerits of the various different processes will be made. Special emphasis is made on relating powder coating with anode fabrication and creep test data.

\subsection{Metal Coating of High Surface Area Substrates}

At the outset it must be mentioned that the most important consideration in developing metal-coated ceramics for creep resistant anode applications is the influence of metal wetting and particle coverage. In all the data reviewed on electroless plating of $\mathrm{LiAlO}_{2}$ substrates obtained in this study, it is clear that metals deposit in the form of globules of various sizes but falling into two principal size populations of $0.1-0.2 \mu \mathrm{m}$ and about $2 \mu \mathrm{m}$ or greater. Generally the metals do not appear to wet either during the plating process or after the sintering process. This is indicative of local nucleation and growth of metal particles during the auto catalytic deposition process. This is not surprising considering the high surface area of the powder being plated. The high surface area affects the preceding steps in conventional electroless plating processes due to inhomogeneous dispersion resulting in incomplete sensitization and activation. Furthermore, for reactive substrates such as $\mathrm{LiAlO}_{2}$, hydrolysis causes additional problems associated with surface changes with concommitant loss of catalytic sites for metal deposition. These factors severely limit the reproducibility of the process. In cases where micrographic evidence for complete metal coverage is seen, examination at higher magnifications suggest that the metal film is comprised of metal globules. In all other cases, the metal layer consisted of discrete globules isolated from each other. In some cases the coated powders examined show that the metal deposits appear to have grown by heterogeneous nucleation from the bath and not directly on the subsirate surface. This could be due to initiation of the metal reduction on a sub-micron particle and subsequent nucleation occurring on that particle. This causes the metal-coated powder to form loose agglomerates and cause large pore formation in the sintered anode plaques.

Metal coating quality is greatly improved by the use of the alternate activation technique presumably due to two important reasons. One is that two aqueous steps have been replaced by a single step which can tolerate high energy dispersion methods such as ultrasonic agitation. The second is that this step, followed by calcination of the powder, leaves behind a thin, uniform coating of the oxide which may act as a reactive bonding aid during the anode sintering procedure. Another important observation is the obvious improvement in metal coating coverage on $\mathrm{LiFeO}_{2}$ substrates. This is attributed to the stability of the substrate in the plating bath. It is clear that substrate bath interactions play an important role, not only in ensuring good unflocculated 
powder dispersions, but also in ensuring uniformity of surface sensitization and activation procedures.

Chernical vapor deposition of $\mathrm{Ni}$ on $\mathrm{LiAlO}_{2}$ substrates have given the best coating uniformity and coverage. Examples of the coating quality are shown in Figure 10. Cross-sections of the anode after creep testing is shown in Figure 11. The Ni metal deposits appear to fall into two categories of population sizes. The smaller deposits are below $1 \mu \mathrm{m}$ and typically lie between 0.2 $0.5 \mu \mathrm{m}$. SEM/EDXS microanalysis from individual particles show $\mathrm{Ni}$ as well as Al signals, supporting the observation of the particle size distribution. The larger particles of metal are clusters of smaller particles and are greater than 5 $\mu \mathrm{m}$ in size. Table 18 shows the results of SEM/EDXS microanalysis. As expected, the smaller particle sizes show higher Al concentrations due to the ionization cross-section penetrating the particle as well as the underlying substrate.

The mean coating thickness of the metal film is $0.3-0.5 \mu \mathrm{m}$. These results suggest that even with the CVD method, it appears that some gas phase nucleation of the Ni powder occurs. This powder deposit is not expected to adhere strongly to the substrate. With further optimization of the process parameters, it may be possible to obtain more contiolled deposition and have greater control over metal loading and coating thickness and uniformity. The economics of this process may, however, be unsuitable for use in production of MCFC anodes. The process requires capital intensive equipment with elaborate controls to handie the extremely toxic Ni-carbonyl gas, and at the present time appears to be suited for batch operation only.

The results from vacuum sputter deposition were very encouraging. The powder was fluidized using a vibratory pan which was tuned to vibrate at the resonance frequency of the powder bed. Once the powder was fluidized, the coating process was begun. The target was made on Monel metal, an alloy consisting of $55 \% \mathrm{Ni}+45 \% \mathrm{Cu}$. The advantage of this process can be seen right away- it is possible to deposit metal alloys simultaneously as long as a target of the alloy is made. (The importance of this is discussed in the next section). This can be exploited even further by depositing a pre-coat of an active metal in order to promote adhesion. The metal distribution on the substrate surface was less uniform as compared to the CVD technique but comparable to or better than the electroless technique. From an economic point of view this process is expected to be less expensive as compared to CVD and continuous processing is possible.

In summary, the best coating technique that provides uniformity of coating and complete metal film coverage is CVD coating. Conventional electroless coating technology is inadequate for coating reactive substrates but with the new surface activation process developed under this program, it appears to give uniform metal deposits. Sputter deposited metal coating appears to have some special advantages such as the ability to coat multiple metals or alloys simultaneously. However the economics of metal-coated anodes using either CVD or sputter deposition has to be carefully evaluated. 
Table 18. SEM/EDXS Microanalysis of CVD Ni Deposits on $\mathrm{LiAlO}_{2}$

\begin{tabular}{|c|c|c|}
\hline Mean Particle Size & $(\mu \mathrm{m})$ & Ni Concentration \\
\hline$(w t \%$, mean $)$ & Al Concentration & (wt \%, mean) \\
\hline $0.2-0.5$ & 65 & 35 \\
\hline $1-2$ & 80 & 20 \\
\hline$>5$ & 99.2 & 0.8 \\
\hline
\end{tabular}

\subsection{Creep Behavior of Sintered Metal-coated Anodes.}

The creep tests performed under this contract have been described in detail earlier. Briefly, the test rigs are designed to follow the creep of anodes as a function of temperature and applied ram pressure over the dur ation of the test. The tests were essentially of a screening nature. Analysis of the data were performed on the basis of the shape of the creep curves, which is indicative of the creep mechanism operative under the various conditions of the creep tests as well as variables in anode morphology. Correlation of the creep results with the morphology was the most challenging and difficult task and also the most instructive. Considerable effort was put in to draw conclusions from the wide scatter in both the experimental variables. Anode microstructures were characterized before and after the creep tests by both Ceramatec and IGT using SEM and porosimetry. IGT performed chemical analyses to verify the $\mathrm{Ni} / \mathrm{Cu}$ ratio and the total metal loading.

In general, for both $\mathrm{LiAlO}_{2}$ and $\mathrm{LiFeO}_{2}$ coated anodes, the measured creep data and correlation with the microstructural observations suggest that the primary creep mechanism is due to particle rearrangement occurring on application of the load. The magnitude of this "primary" creep is governed by both the wetting (and adhesion) characteristics of the metal film as well as the uniformity of the metal deposition. The two factors are somewhat inter-related and therefore experiments to separately investigate the two phenomena could not be performed. The available literature on failure of metal-ceramic bonded systems is rather limited but a failure mode frequently reported is fracture in the ceramic, adjacent to the interface. Similar conditions do not apply in the case of metal-coated anodes where no special efforts can be easily made to compression bond the metal/ceramic owing to the porosity requirement of the anode structure. Thus, contrary to the literature, the common failure mode in metal-coated anodes is separation of the metal and ceramic at the interface.

Analysis of the creep test data are discussed below, with respect to the microstructures and anode fabrication characteristics.

\subsection{Creep Behavior of Metal-coated $\mathrm{LiAlO}_{2}$}

Figures 41 and 42 show the creep of $\mathrm{LiAlO}_{2}$ anodes tested at $650^{\circ} \mathrm{C}$ under a pressure of $100 \mathrm{psi}$. Creep data at $700^{\circ} \mathrm{C}$ and at $50 \mathrm{psi}$ are limited and 


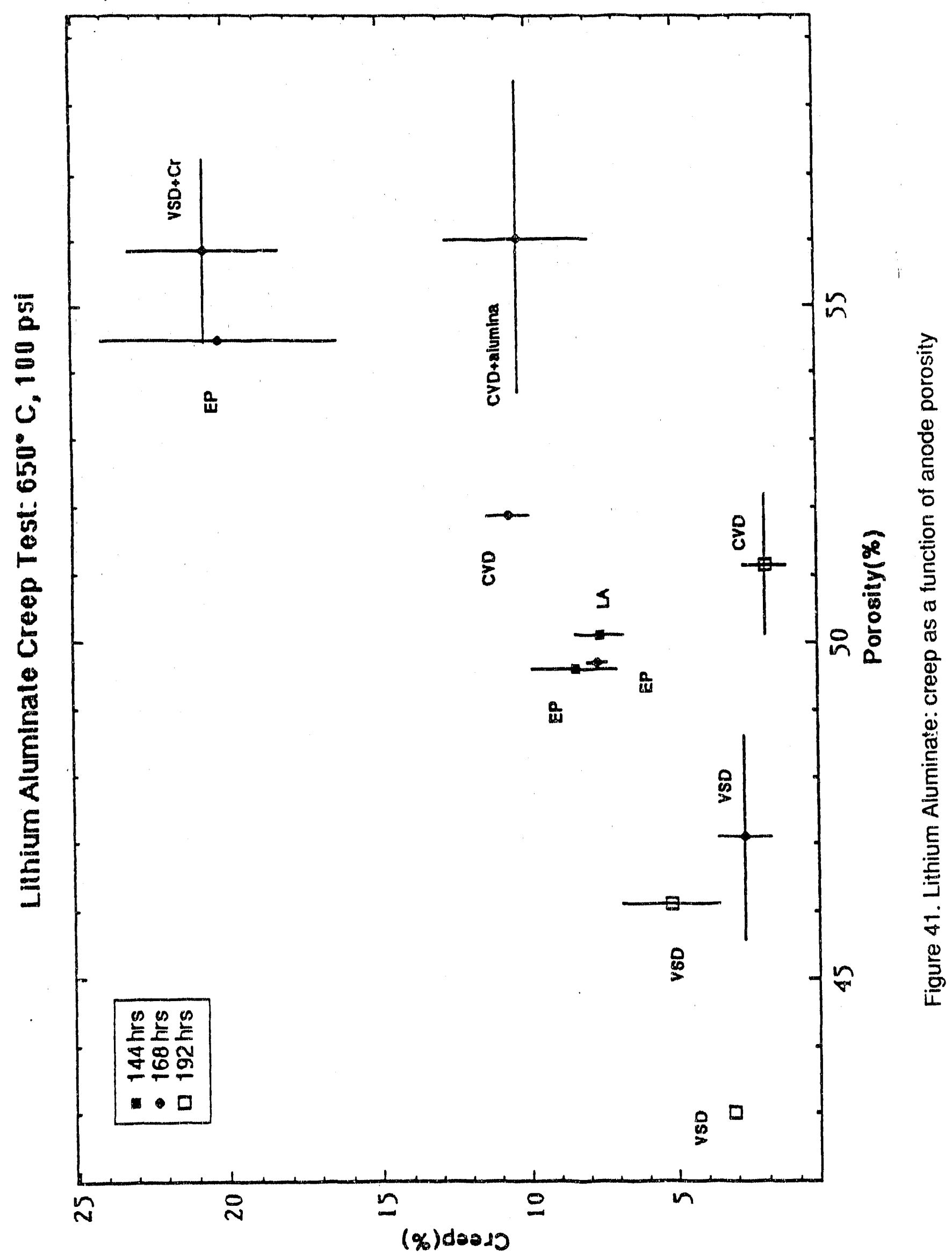




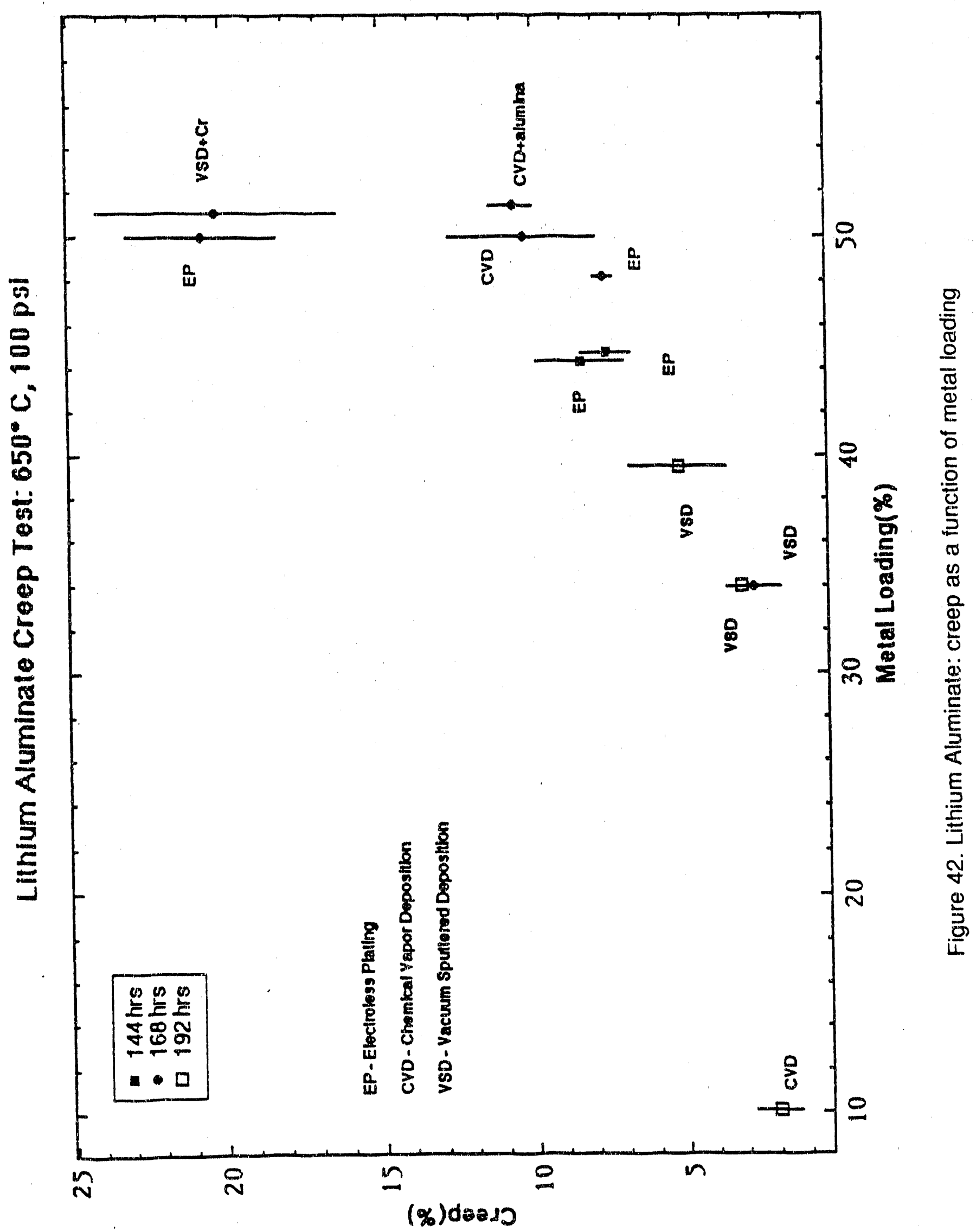


hence are not plotted in a similar fashion. Comparative comments are made later.

In the case of electroless metal coated anodes, one finds that the creep averages about $7.5 \%$ for anodes with $\sim 47 \%$ metal loading. For a slightly higher metal loading of $\sim 49 \%$, the measured creep seems anomalously high at $\sim 22 \%$. However, comparison of the porosity indicates that for those anodes which exhlbited the high creep, the porosity was also higher. While exact quantitative analysis cannot be made in the absence of data on metal- $\mathrm{LIAlO}_{2}$ bond strength, the trend is consistent with the fact that in anodes with greater porosity the cross-section available to resist the applied pressure is lower thus raising the magnitude of the shear stress acting on the particles. Examination of the creep data Test \# 2.3.1.b-1 and 2 show that the bulk of the creep occurs in the first 1-2 hours due to particle-particic sliding. The microstructure of these anodes shows that the metal was preduminantly located at triple grain junctions partly due to poor coating uniformity and partly due to dewetting. Similar creep behavior is seen for Test \# -3 and -4 . The data do not show any appreciable difference under the two different pressures of 50 and 100 psi. This is not surprising since the metal/ceramic bond strength is very weak to begin with. The creep data indicate linear behavior with time in the "secondary" creep region. This is attributed to sintering of the metal globules in contact with each other after the initial particle rearrangement. Further confirmation of this mechanism is seun on examination of the temperature dependence of the slope of the secondary creep characteristics. A small but systematic increase in the slope is seen at the higher temperatures indicative of faster diffusion kinetics.

The creep behavior of CVD coated $\mathrm{LIAIO}_{2}$ anodes indicates that although the coating is more uniform and complete, the creep is higher with an average of $10.5 \%$. SEM analysis indicates that while the metal coverage is very uniform and complete, after sintering the metal seems to redistribute over the surface to triple grain junctions. This is a consequence of metal dewetting over the surface. The mean pore size of such anodes was $\sim 16.5 \mu \mathrm{m}$. In this case as well, the bulk of the creep is expected to be primary with particles sliding past each other to reduce to void space. On ODS CVD metal-coated anodes using $\mathrm{Al}_{2} \mathrm{O}_{3}$ the effect is small. Interpretation of this is difficult considering that the anode porosity made with ODS powders have higher porosity. The effect on metal loading appears to be much larger with the $10 \%$ metal loaded CVD anodes exhibiting about $3 \%$ creep. This is consistent with the mechanisms proposed where primary creep occurs when metal globules bridge $\mathrm{LiAlO}_{2}$ particles.

The creep in sputter coated metal/LiAlO 2 anodes is surprisingly lower than expected. This could be consequence of a combination of lower metal loading $(\sim 40 \%)$, lower porosity $(\sim<4 \%)$ and lower mean pore size $(7 \mu \mathrm{m})$. In the case of anodes with greater metal loading and higher porosity, the creep is much greater. These anodes also had a pre-coat of $\mathrm{Cr}$ metal sputtered on to improve adhesion. The results suggest that either the adhesion properties were not affected appreciably or the effect of morphology was greater. The experimental data are insufficient to delineate the two effects. 


\subsection{Creep Behavior of Metal-coated LIFeO2 Anodes}

In case of $\mathrm{LiFeO}_{2}$ anodes, the major difference is that the metal wetting characteristics are more favorable. Thus a better bond is to be expected between the metal and the ceramic, reducing the amount of primary creep. Figures 43 and 44 show the general trends in the creep behavior of metalcoated $\mathrm{LiFeO}_{2}$ anodes. Creep is relatively insensitive to both metal loading and anode porosity, indicative that once particle rearrangement occurs secondary creep mechanism dominates the creep behavior. Creep characteristics are shown for Test \# -5. The data show that the magnitude of the primary creep is less than $\sim 2 \%$. Further creep is as expected for diffusion driven process. The data for rig 2 for anodes with higher metal loading are inconsistent with the trend and should be disregarded due to a malfunctioning test rig. Higher anode creep is exhibited for anodes with higher mean pore size and porosity. This is consistent with observations for $\mathrm{LiAlO}_{2}$ anodes. However, the overall creep characteristics are superior for metal coated $\mathrm{LiFeO}_{2}$ and it exhibits the potential for a viable alternate anode material.

\subsection{Summary}

In summary, the following points emerge from the analysis of the microstructure/creep measurements relations.

1. For any metal-coated ceramic anode, the predominant creep mechanism is due to particle rearrangement. This mechanism will dominate creep behavior even if the metal wets the ceramic but does not adhere well.

2. The anode porosity must be as low as possible consistent with anode performance criteria such as polarization phenomena associated with mass transport limitations in such porous electrodes. The mean pore size must also be as low as possible, consistent with performance criteria.

3. Metal coated anodes will exhibit lower creep at lower metal loadings. In fact, the data suggest that completeness of coverage is not the important criterion. Rather, uniformity of metal deposition is more important. It is conceivable that if the metal deposits adhere well, then in a three dimensional porous structure there can be contiguity of metal contacts leading to anode conductivity.

4. The factors affecting metal coating coverage have been mentioned earlier. One consideration is the deposition of metal alloys. In any process which deposits metals sequentially, the driving force for alloy formation will generally exceed the force for wetting (and hence adhesion ) on the ceramic. This couid also lead to some Kirkendall porosity at the metal/ceramic interface. These factors will weaken the bond and thus lead to poor mechanical properties. Thus there may be advantage in deposition of alloys on the surface. 


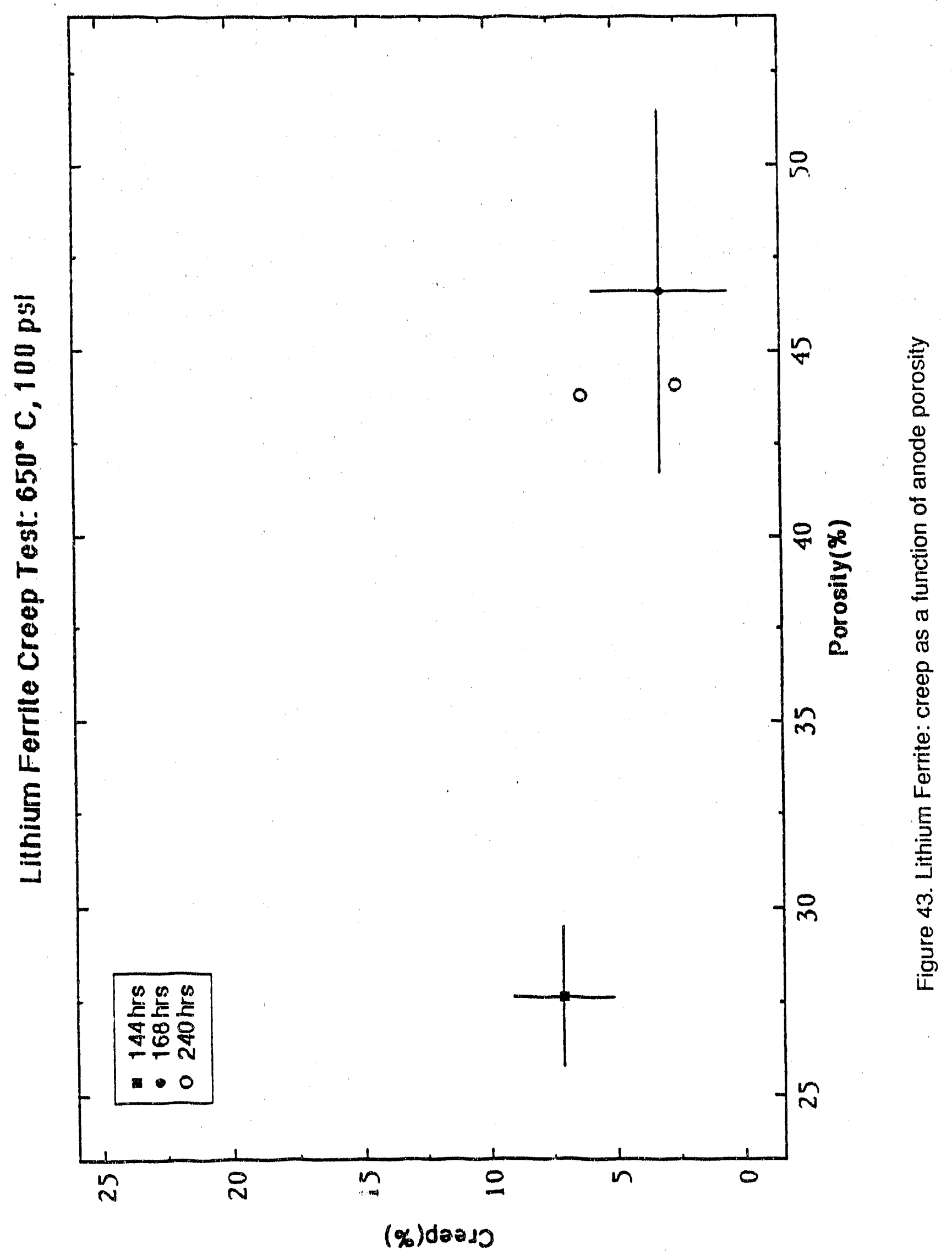




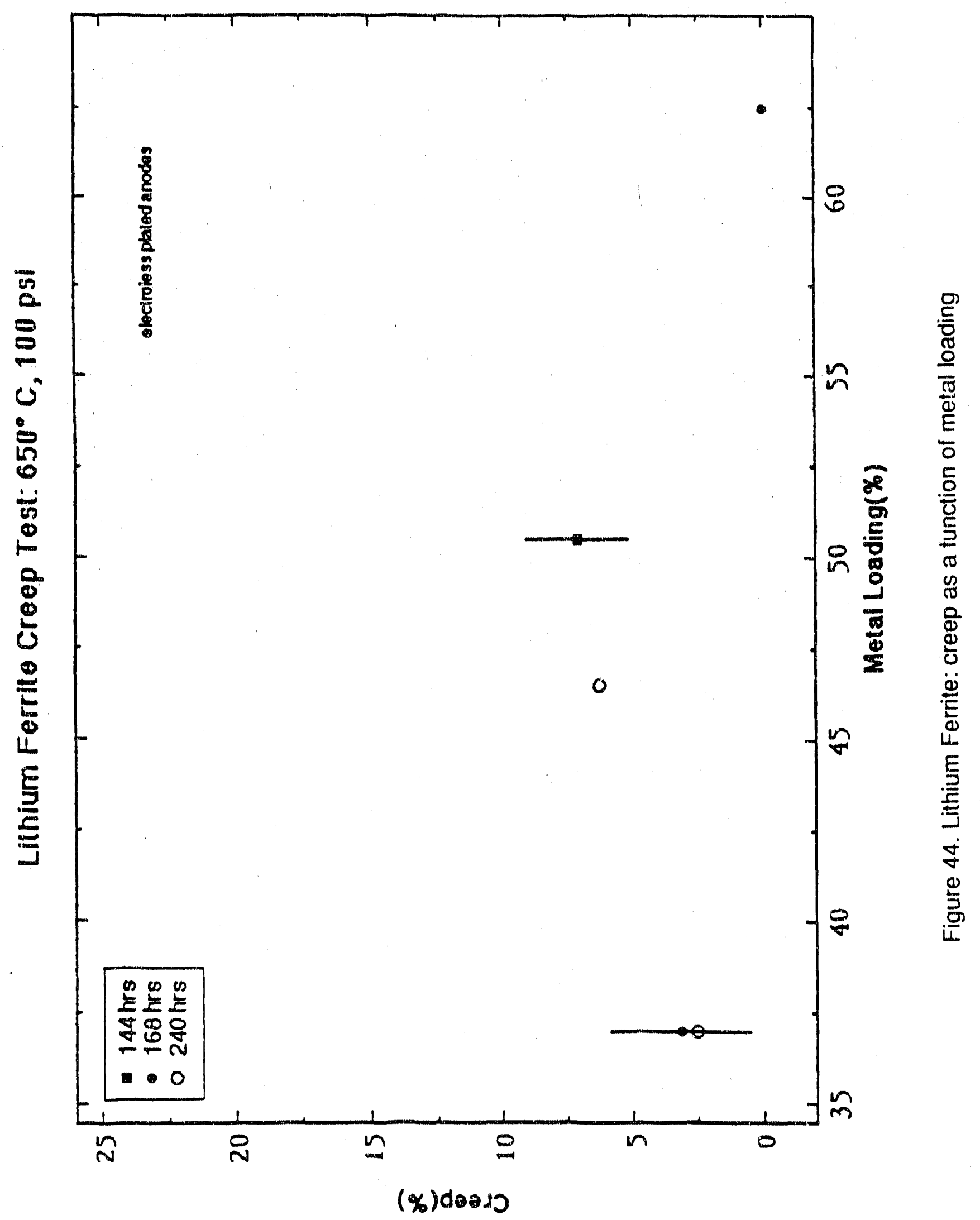


5. Electroless plating of metal on high surface area substrates is generally very difficult. Considerable technology development has been done during this contract in this area. Specifically, two important advances have been made. A new method for a single step homogeneous surface activation of reactive powders has been developed. During the course of this contract this has led to an improvement both in the metal wetting characteristics as well as coating uniformity, as evidenced by SEM investigations of the microstructure. The anode morphology was also improved as a consequence of the improvement in the metal coating process.

6. The metal-coated $\mathrm{LiFeO}_{2}$ anode was developed which has demonstrated great potential as a creep resistant anode. The basic concept has been successfully proven, although some improvements in both metal adhesion as well as anode morphology could be made. These improvements are expected to lead to reduced primary creep and thus enhance creep resistance.

7. Finally, from the enormous body of data generated, the fundamental requirements for successful application of metal coated anode technology have been identified. The important criteria are (a) thermodynamically stable metal film at the given temperature and oxygen activity at the anode, (b) strong adhesion between the metal film and the ceramic substrate. From a technological standpoint, general requirements for anode fabrication/morphology have been identified. 


\subsection{CONCLUSIONS AND RECOMMENDATIONS}

The current state-of-the-art MCFC anodes suffer primarily from relatively high creep during cell operation, thus limiting stack endurance. Preliminary work at General Electric suggested that successful development of a metal coated ceramic substrate could mitigate the high creep behavior. However indications were that inadequate metal coverage and weak metal/ceramic adhesion owing to poor wetting led to inadequate creep resistance. Consequently this program focussed on developing metal coating technology for various ceramic substrates $\left(\mathrm{LIAlO}_{2}, \mathrm{SrTiO}_{3}\right.$, and $\left.\mathrm{LiFeO}_{2}\right)$ with a view of improving metal coating uniformity and addressing metal wetting on the ceramic substrates. Electroless metal plating processes were developed especially for hygroscopic substrates such as $\mathrm{LiAlO}_{2}$ and for high surface area ceramic substrates. A new method for a single step homogeneous surface activation of reactive powders was developed which led to an improvement both in the metal wetting characteristics as well as coating uniformity. The creep resistance of a metal coated ceramic substrate was shown to be critically related to dewetting of the metal at elevated temperatures. Alternate substrates that allowed better wetting of the metal on the ceramic such as $\mathrm{LiFeO}_{2}$ and $\mathrm{Li}_{2} \mathrm{MnO}_{3}$ were identified. Cu/Ni-coated (50:50 mol ratio, 50 w/o metal loading) $\mathrm{LiFeO}_{2}$ anodes were optimized to meet MCFC anode specifications. Metal-coated $\mathrm{LiAlO}_{2}$ substrates were also developed.

For metal coated ceramic anodes, the predominant creep mechanism was found to be due to particle rearrangement. To achieve low creep behavior the metal must not only wet the ceramic but must adhere to the substrate as well. Among the variables that can be controlled during anode fabrication, the porosity and mean pore size play an important role in controlling creep behavior. The anode porosity as well as mean pore size must be as low as possible consistent with anode performance criteria such as polarization phenomena associated with mass transport limitations porous electrodes. The creep data also suggest that lower metal coating is preferable. If the metal coating exhibits good adherence and contiguous coverage in three dimensions, the anode would have low creep as well as meet performance criteria.

Thus the important criteria are:

(a) thermodynamically stable metal film at the given anode environment

(b) strong adhesion between the metal film and the ceramic substrate.

Of the three substrates evaluated, $\mathrm{LiFeO}_{2}$ exhibited lower creep primarily attributed to superior metal adhesion. Metal-coated $\mathrm{LiFeO}_{2}$ anodes were developed which demonstrated great potential as creep resistant anodes. Successful in-cell testing proved the basic concept. However, further work needs to be done to optimize the anode microstructure. The technology developed in this program can be developed further by optimization of metal adhesion to the substrate and tailoring of anode morphology in order to improve anode characteristics. 


\subsection{REFERENCES}

[1] C.D. lacovangelo, "Metal Plated Ceramic - A Novel Electrode Material," J. Electrochem. Soc. 113, No. 7, 1359 (1986).

[2] United Technologies Corporation Progress Report No. 10, DE-AC0179ET15440, FCR-4267 (April 1982).

[3] C.D. lacovangelo in N.olten Carbonate Fuel Cell Technology, J.R. Selman and T.D. Claar, eds. p. 397, The Electrochem. Soc. Proceedings Serie. Pennington, NJ j1984).

[4] "Development of Molten Carbonate Fuel Cell Power Plant," Final Report, March 1985, Contract No. DE-AC02-ET17019, General Electric Co.

[5] J.R. Selman and L.G. Marianowski in Molten Salt Technology D.G. Lovering, ed. p.323, Plenum, NY (1982).

[6] J.R. Selman and H.C.IMaru, Adv. Molten Salt Technology G. Mamantov and J. Braunstein, eds. , 4, 1959 (1981).

i7] "Development of Metal-Coated Ceramic Anodes for Molten Carbonate Fuel Cells," Annual Report, Ceramatec, inc., Contract No, DE-AC21. 85MC22194, Sept. 1986.

[8] A.J. Appleby, "Advanced Fuel Cell Technology," EPRI J., p.63, December 1984.

[9] R. Standing and M. Nicholas, J. Mat. Science 13, p. 1509 (1978). 


\section{ACKNOWLEDGEMENTS}

Ceramatec and IGT wish to acknowledge the contributions of various individuals who assisted the porgress on this program:

Department of Energy, for financial support on the program.

F.D. Gmeindl, Project Manager

W.J. Huber, Project Manager

Argonne National Laboratories, for technical monitoring on the program.

R.D. Pierce, for technical advice

N.Q. Minh and

T.D. Kaun for technical discussions and advice.

Electric Power Research Institute, for permission to use data generated under Project 40227-04 to IGT.

Ed Thelman, Consultant to Ceramatec, for assistance in alternate metal coating techniques.

D. Lynn Johnson, Professor, Northwestern University, and Consultant to IGT for a critical program review and technical advice.

Estella Ong and

Dave Vasil, IGT, for technical discussions.

Dianne S. Erickson, IGT, for porosimetry measurements.

Art Moler,

Kevin Walsh,

Brian Rolfson, and

Scott Weber, Cerarnatec, for plating process developement.

Dave Prouse, Ceramatec, for substrate powder synthesis.

Phill Petty, Ceramatec, for synthesis and sintering process development. 
Appendix A

Determination of Metal Loading 
The procedure involves etching the metal away from a known weight of the coated powder, filtering and drying the residue (LiFeO2 powder substrate) and determining the weight lost. The weight loss is attributed to the metal that is etched out. One uncertainty in the procedure is the amount of fines lost in the filtration step. The variation introduced by this uncertainty was determined to be about $\pm 5-7 \%$. Another possibility is that the etchant (50\% nitric or acetic acid) may be dissolving some of the LiFeO2. A known amount of uncoated $\mathrm{LiFeO}_{2}$ powder was stirred in the etchants, The residue was filtered, dried and weighed. As a control, the procedure was repeated with DI water. No dissolution of the $\mathrm{LiFeO}_{2}$ was detected.

An alternate technique based on redox titration was developed to determine the amount of $\mathrm{Cu}$ in the deposit. The amount of Ni loading was taken to be the difference between the two results, total metal loading and the amoun t of $\mathrm{Cu}$. The redox method for determination of $\mathrm{Cu}$ content is described below.

A determination of the amount of $\mathrm{Cu}$ is made using the iodometric method. A solution containing $\mathrm{Cu}^{2+}$ ions (made by dissolving the $\mathrm{Cu}$-coated ceramic powder in nitric acid) can be reduced to $\mathrm{Cu}^{1+}$ with an excess of iodide ions. An equivalent amount of the 1 - is oxidized to elementary iodine which is then titrated against a standardized thiosulfate solution. The reactions are as follows:

$2 \mathrm{Cu}^{2+}+5 \mathrm{I}^{-} \Rightarrow \mathrm{Cu}_{2} \mathrm{I}_{2}+\mathrm{I}_{3}^{-}$
$\mathrm{I}_{3}^{-}+2 \mathrm{~S}_{2} \mathrm{O}_{3}^{2-}=\Rightarrow 31^{-}+\mathrm{S}_{4} \mathrm{O}_{6}^{2-}$
$2 \mathrm{Cu}+2+2 \mathrm{I}^{-}+2 \mathrm{~S}_{2} \mathrm{O}_{3}^{2-}=\Rightarrow \mathrm{Cu}_{2} \mathrm{I}_{2}+\mathrm{S}_{4} \mathrm{O}_{6}$

Because $\mathrm{Cu}$ and thiosulfate ions are in $1: 1 \mathrm{~mol}$ ratio, the amount of $\mathrm{Cu}$ present in a sample is equivalent to the volume of thiosulfate titrated. 
Appendix B

Summary of Fabrication Trials of Metal Coated Anodes 


\begin{tabular}{|c|c|c|c|c|c|c|c|c|}
\hline 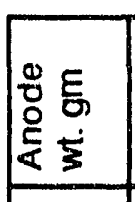 & $\begin{array}{l}0 \\
0 \\
0 \\
0 \\
0 \\
0 \\
0 \\
0\end{array}$ & 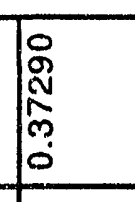 & $\begin{array}{l}0 \\
0 \\
0 \\
0 \\
0 \\
0 \\
0 \\
0\end{array}$ & $\begin{array}{l}0 \\
\begin{array}{l}0 \\
0 \\
0 \\
0 \\
0 \\
0\end{array} \\
\end{array}$ & \begin{tabular}{|l} 
\\
0 \\
$\vdots$ \\
7 \\
0 \\
0 \\
\end{tabular} & $\begin{array}{l} \\
\begin{array}{l}0 \\
0 \\
0 \\
0 \\
0 \\
0\end{array} \\
\end{array}$ & \begin{tabular}{|l} 
\\
0 \\
0 \\
0 \\
0 \\
0 \\
0
\end{tabular} & \\
\hline 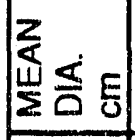 & 旅 & 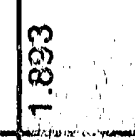 & \& & . & 总 & 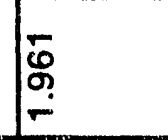 & 总 & \\
\hline 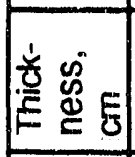 & $\begin{array}{l}0 \\
0 \\
0 \\
0 \\
0 \\
0\end{array}$ & $\begin{array}{l}0 \\
\hat{0} \\
0 \\
0\end{array}$ & 唇 & $\begin{array}{l}0 \\
0 \\
0 \\
0 \\
0 \\
0\end{array}$ & \begin{tabular}{|l}
0 \\
8 \\
0 \\
0 \\
0 \\
0
\end{tabular} & \begin{tabular}{|l} 
\\
$\vdots$ \\
0 \\
0 \\
0
\end{tabular} & \begin{tabular}{|c}
0 \\
$\begin{array}{c}0 \\
0 \\
0 \\
0\end{array}$ \\
\end{tabular} & $\begin{array}{l}0 \\
0 \\
0 \\
0 \\
0 \\
0\end{array}$ \\
\hline 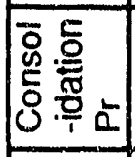 & 㒸总 & 骂 & 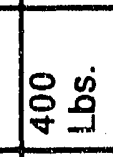 & 草皇 & 兑喤 & 总鸪 & 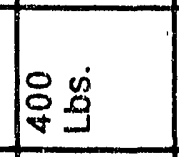 & 苛总 \\
\hline 岕崖 & $\mid \underline{\underline{\underline{E}}}$ & $\mid \underline{\underline{E}}$ & 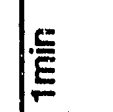 & 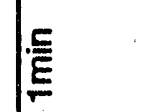 & $\mid \begin{array}{c}\text { 㫐 } \\
\underline{E}\end{array}$ & 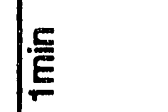 & $\mid \begin{array}{c}\text { E } \\
\underline{\underline{E}}\end{array}$ & $\mid \underline{\underline{E}}$ \\
\hline 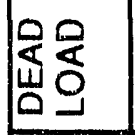 & 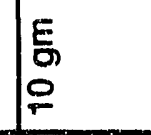 & 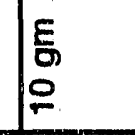 & 原 & \begin{tabular}{|l}
$E$ \\
E \\
\end{tabular} & $\begin{array}{l}\text { E } \\
\text { E } \\
\text { 足 }\end{array}$ & 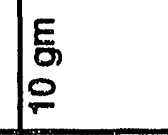 & 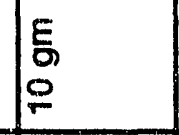 & 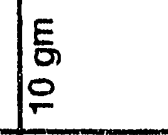 \\
\hline 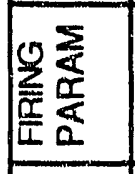 & $\begin{array}{l}0 \\
0 \\
0 \\
0\end{array}$ & $\begin{array}{l}0 \\
0 \\
\dot{8}\end{array}$ & $\begin{array}{l}0 \\
0 \\
0 \\
0\end{array}$ & 它 & 总 & $=$ & 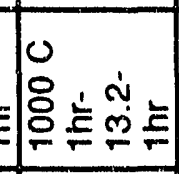 & $\begin{array}{ll}0 \\
0 \\
0 \\
0\end{array}$ \\
\hline $\begin{array}{ll}0 \\
0 \\
0\end{array}$ & 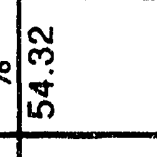 & 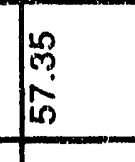 & 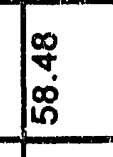 & \begin{tabular}{|l} 
\\
\\
$\dot{0}$ \\
0
\end{tabular} & 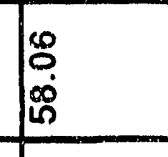 & 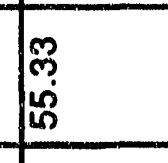 & 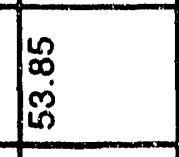 & 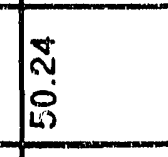 \\
\hline $\begin{array}{l}\infty \\
\frac{0}{2} \\
\sum\end{array}$ & & & & & & & & \\
\hline 崖 & 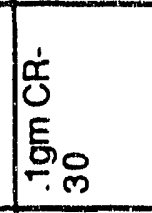 & 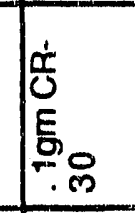 & 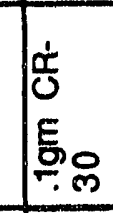 & 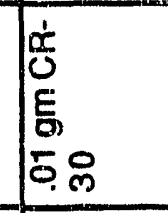 & 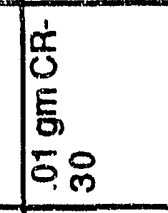 & 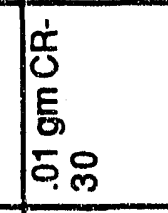 & 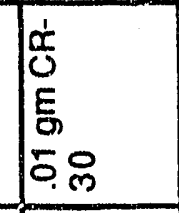 & 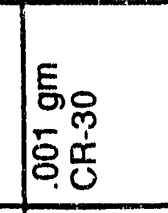 \\
\hline$\sum_{0}^{\bar{z}}$ & 峁 & 第 & 㐌 & 品 & 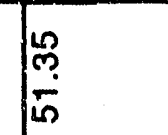 & 然 & 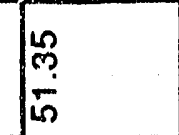 & 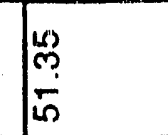 \\
\hline 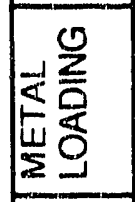 & $\begin{array}{l}0 \\
0 \\
0 \\
5 \\
\end{array}$ & 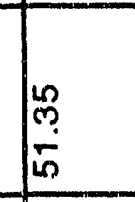 & 萬 & 隹 & 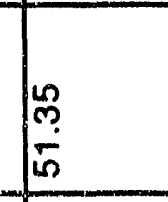 & 萬 & 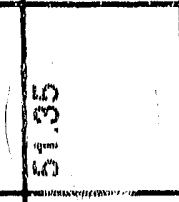 & 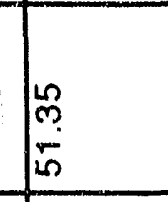 \\
\hline \begin{tabular}{|l} 
产䍃 \\
\end{tabular} & 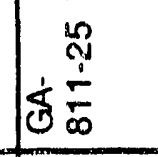 & 商 & 商 & 商 & 总 & 产 & 势 & 帝 \\
\hline 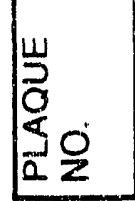 & 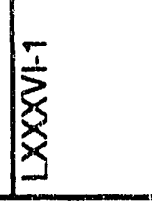 & 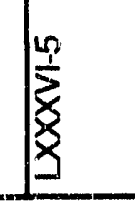 & $\begin{array}{l}\frac{9}{2} \\
\frac{1}{2} \\
3\end{array}$ & 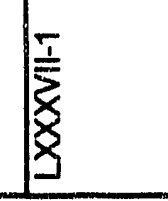 & 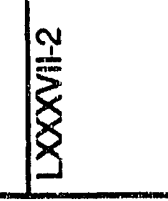 & 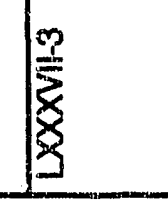 & 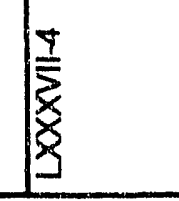 & \begin{tabular}{|l} 
\\
$\bar{z}$ \\
\end{tabular} \\
\hline
\end{tabular}




\begin{tabular}{|c|c|c|c|c|c|c|c|c|c|c|c|c|}
\hline $\begin{array}{l}\hat{0} \\
\overline{8} \\
\overline{8}\end{array}$ & |ֶָ̃ & 侻 & 旅 & 确 & 命 & 亦 & W & 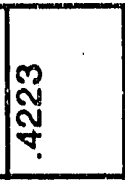 & 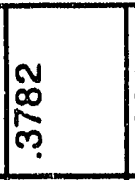 & 离 & 㱏 & 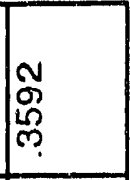 \\
\hline & & 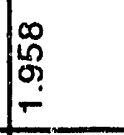 & \begin{tabular}{|l} 
卓 \\
o. \\
\end{tabular} & 总 & \begin{tabular}{|l} 
\\
$\sigma$ \\
\end{tabular} & 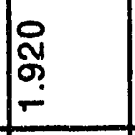 & 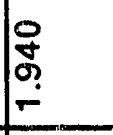 & 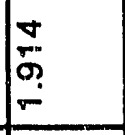 & 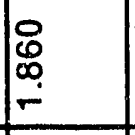 & 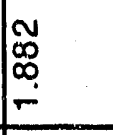 & \begin{tabular}{l}
0 \\
0 \\
0 \\
\hdashline \\
\end{tabular} & \begin{tabular}{|l}
$\bar{\infty}$ \\
$\vdots$ \\
\hdashline \\
\end{tabular} \\
\hline \begin{tabular}{|l|} 
\\
8 \\
0 \\
0 \\
0 \\
\end{tabular} & $\begin{array}{l}\begin{array}{c}0 \\
0 \\
0 \\
0 \\
0\end{array} \\
\end{array}$ & \begin{tabular}{|l} 
\\
$\vdots$ \\
$\vdots$ \\
0 \\
0
\end{tabular} & \begin{tabular}{|c|} 
\\
0 \\
0 \\
0 \\
0
\end{tabular} & 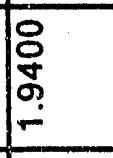 & \begin{tabular}{|l|} 
\\
0 \\
0 \\
0 \\
0 \\
\end{tabular} & \begin{tabular}{|l|} 
\\
0 \\
0 \\
0 \\
0
\end{tabular} & \begin{tabular}{|l|} 
\\
0 \\
0 \\
0 \\
0 \\
\end{tabular} & \begin{tabular}{|l|} 
\\
\\
0 \\
0 \\
0 \\
\end{tabular} & \begin{tabular}{|l} 
\\
0 \\
0 \\
0 \\
0
\end{tabular} & 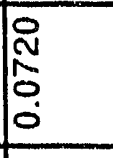 & \begin{tabular}{|l} 
\\
\\
0 \\
0 \\
0 \\
\end{tabular} & \begin{tabular}{|l} 
\\
0 \\
0 \\
0 \\
0
\end{tabular} \\
\hline 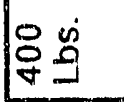 & 字总 & 名骂 & 怼宫 & 客 & 宫骂 & 家弟 & 家宵 & 号骂 & 号。 & 品音 & 号总 & 荇兽 \\
\hline $\mid \underline{\underline{E}}$ & 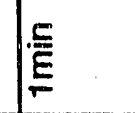 & 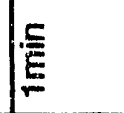 & 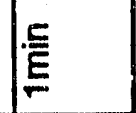 & $\mid \begin{array}{c}\text { 毫 } \\
\end{array}$ & 只 & 乒 & $\mid$ & 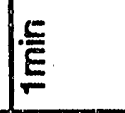 & $\mid \begin{array}{c}\underline{\underline{\underline{E}}} \\
\underline{\underline{E}}\end{array}$ & 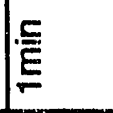 & $\mid \begin{array}{c}\underline{\underline{\underline{E}}} \\
\underline{\underline{E}}\end{array}$ & 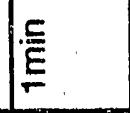 \\
\hline $\begin{array}{l}E \\
\text { E } \\
0\end{array}$ & \begin{tabular}{|l} 
E \\
E \\
$\vdots$
\end{tabular} & $\begin{array}{l}E \\
\\
0 \\
0\end{array}$ & $\begin{array}{l}\text { E } \\
\text { 吾 } \\
\end{array}$ & $\begin{array}{l}\text { E } \\
\text { : } \\
\end{array}$ & $\begin{array}{l}\text { E } \\
\text { - } \\
\end{array}$ & \begin{tabular}{|l}
$E$ \\
\\
\end{tabular} & 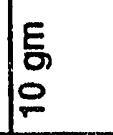 & $\begin{array}{l}\text { E. } \\
\text { - } \\
\end{array}$ & \begin{tabular}{|l}
$E$ \\
$\overline{0}$ \\
0 \\
\end{tabular} & $\begin{array}{l}\text { E⿸厂 } \\
\text { O } \\
\end{array}$ & 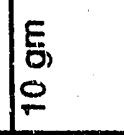 & $\begin{array}{l}\text { E } \\
\text { O } \\
\end{array}$ \\
\hline $\mid$ & 它 & 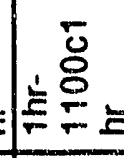 & 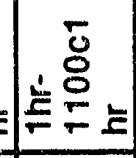 & . & 定 & 点离 & 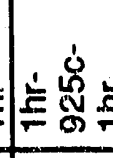 & 定 & 悹 & 总 & 总 & 点兽 \\
\hline 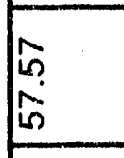 & & & & 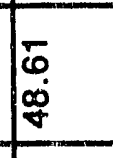 & 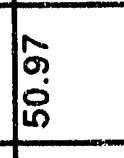 & 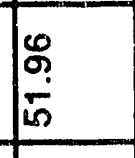 & 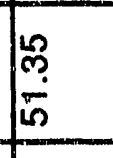 & 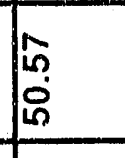 & 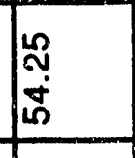 & 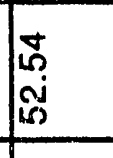 & 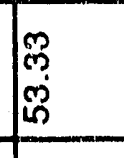 & 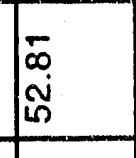 \\
\hline & & & & & $\stackrel{\infty}{\circ}$ & & & & & & & \\
\hline $\begin{array}{l}E \\
50 \\
50 \\
0.0 \\
0\end{array}$ & 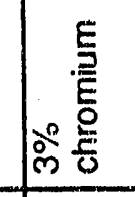 & 章 & 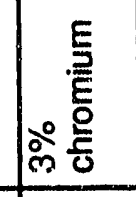 & & & & & & & & & \\
\hline 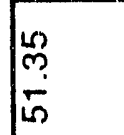 & & & & 色 & 贶 & 第 & 点 & 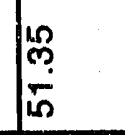 & 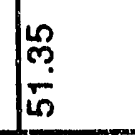 & 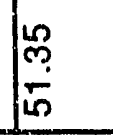 & 萬 & 柋 \\
\hline 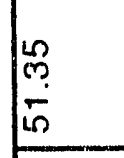 & $\xi$ & j & f & 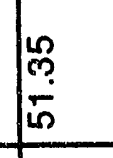 & 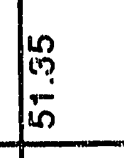 & 色 & 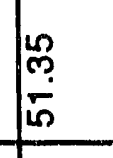 & 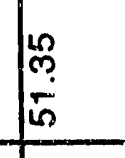 & 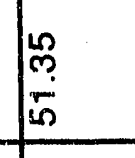 & $\frac{n}{m}$ & $\begin{array}{l}m \\
m \\
m \\
m \\
\end{array}$ & 給 \\
\hline$\stackrel{\stackrel{\sim}{N}}{\frac{N}{\infty}}$ & 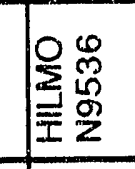 & 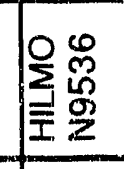 & 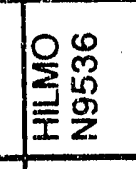 & 先 & 商 & 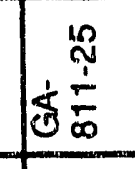 & 昰 & 然 & 产 & 点 & 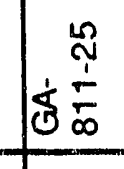 & 蛋 \\
\hline 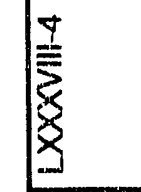 & 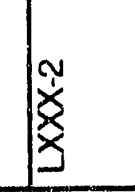 & $\begin{array}{l}\mathbf{m} \\
\mathbf{3} \\
\end{array}$ & \begin{tabular}{|l} 
\\
\\
0
\end{tabular} & \begin{tabular}{|l|l|} 
\\
\end{tabular} & 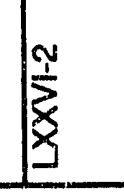 & 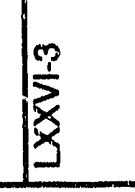 & 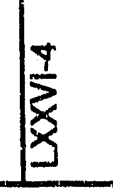 & 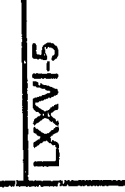 & 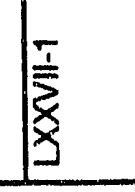 & 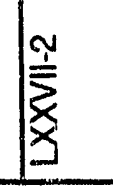 & 离 & 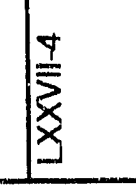 \\
\hline
\end{tabular}




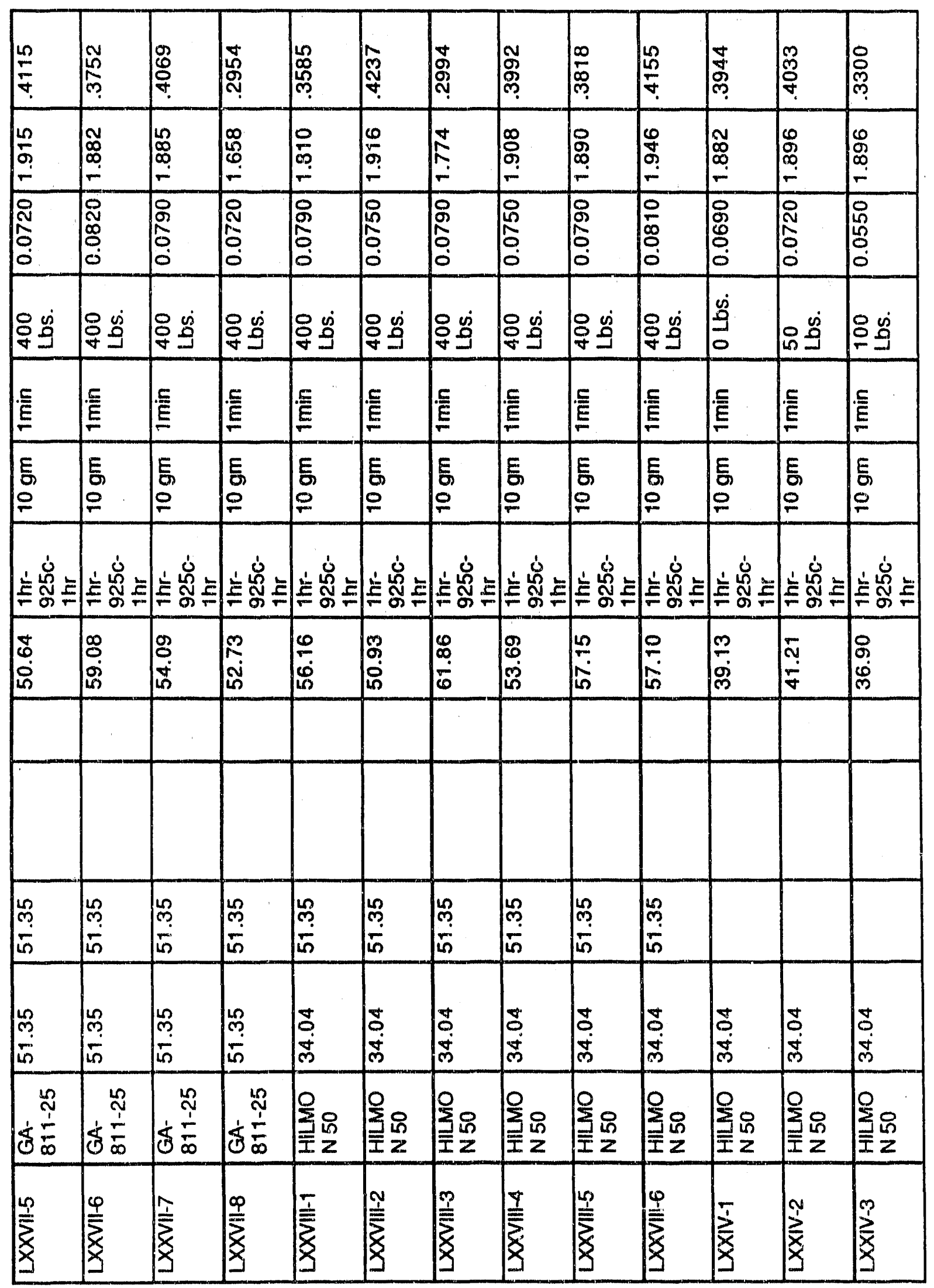




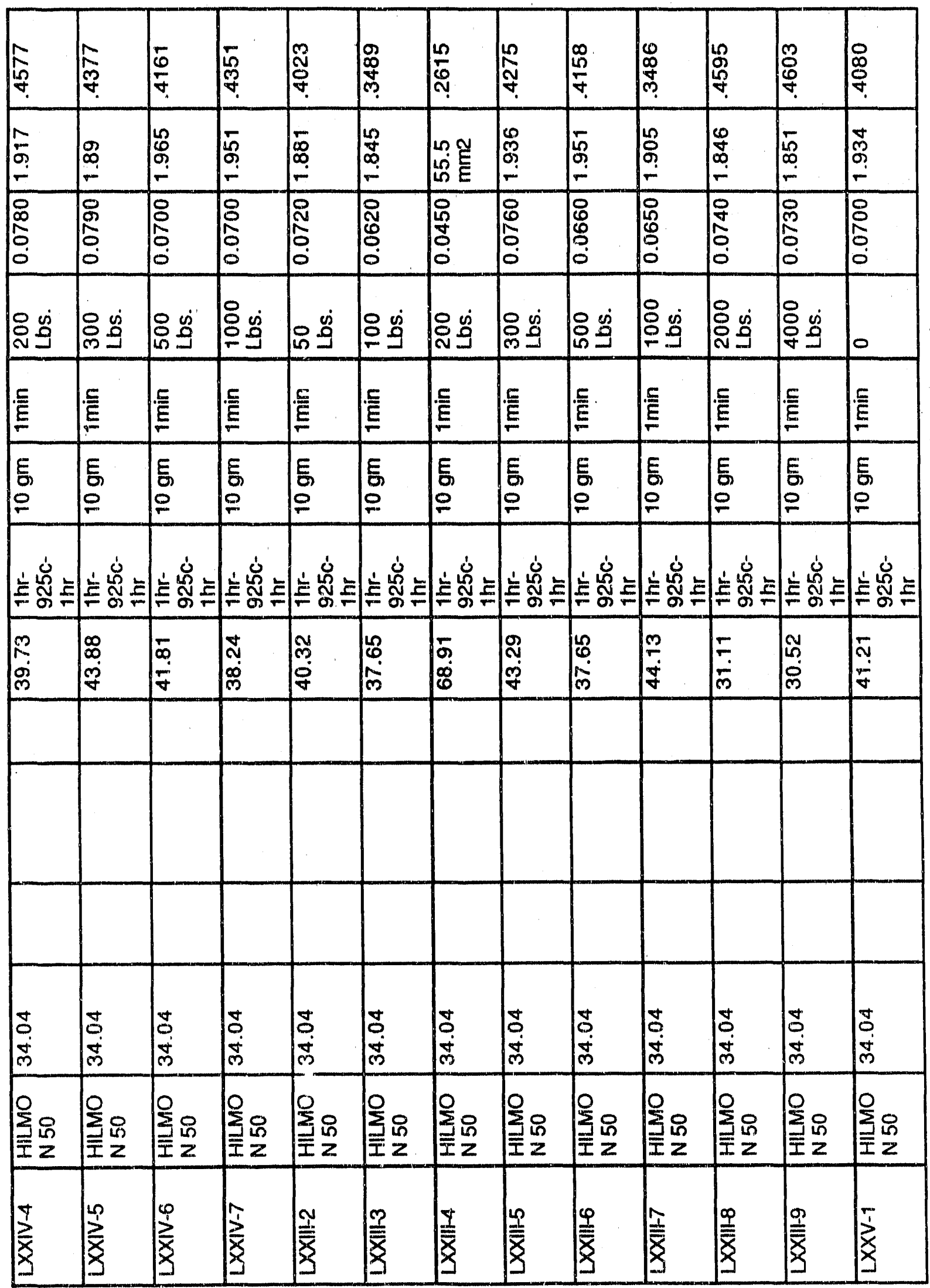




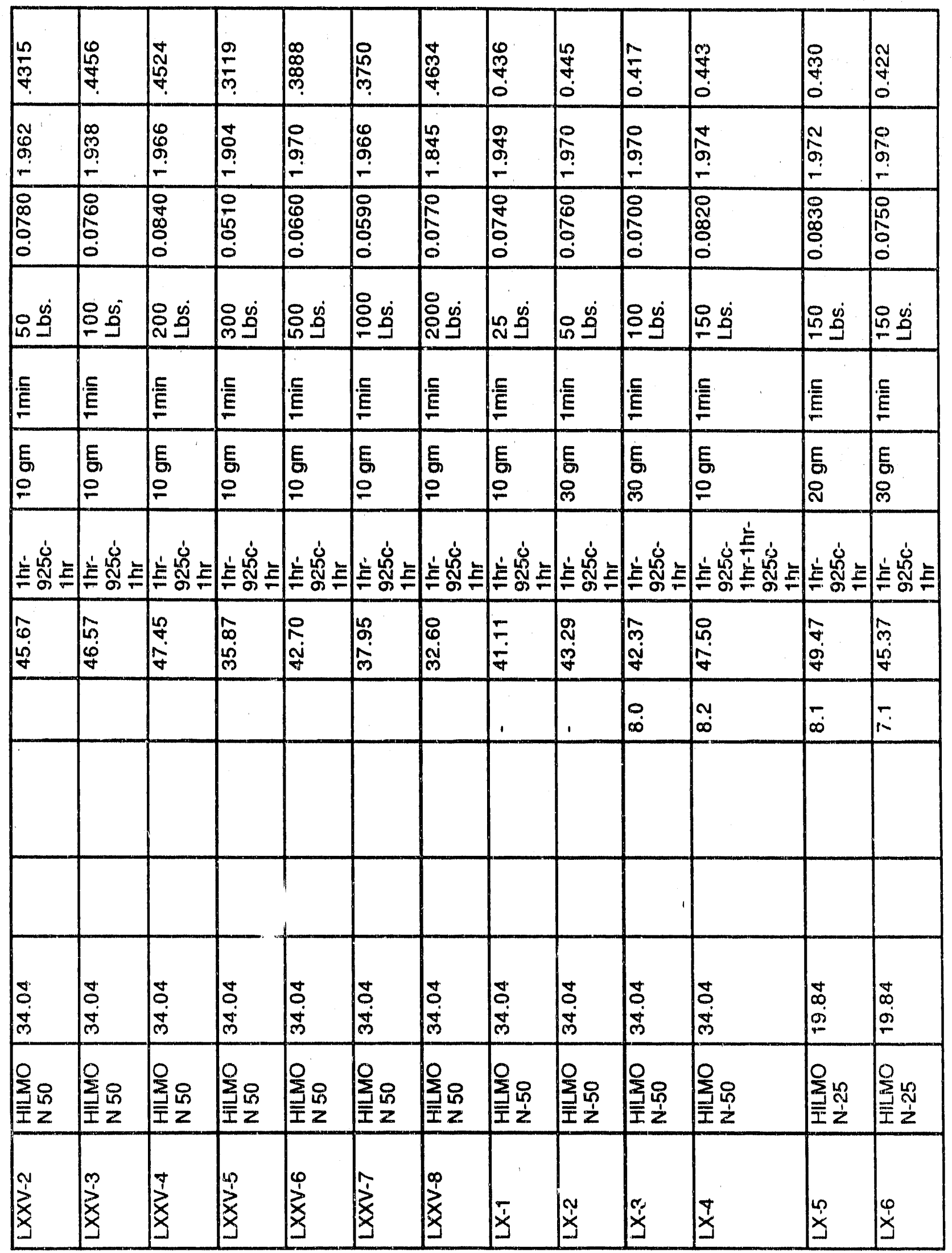




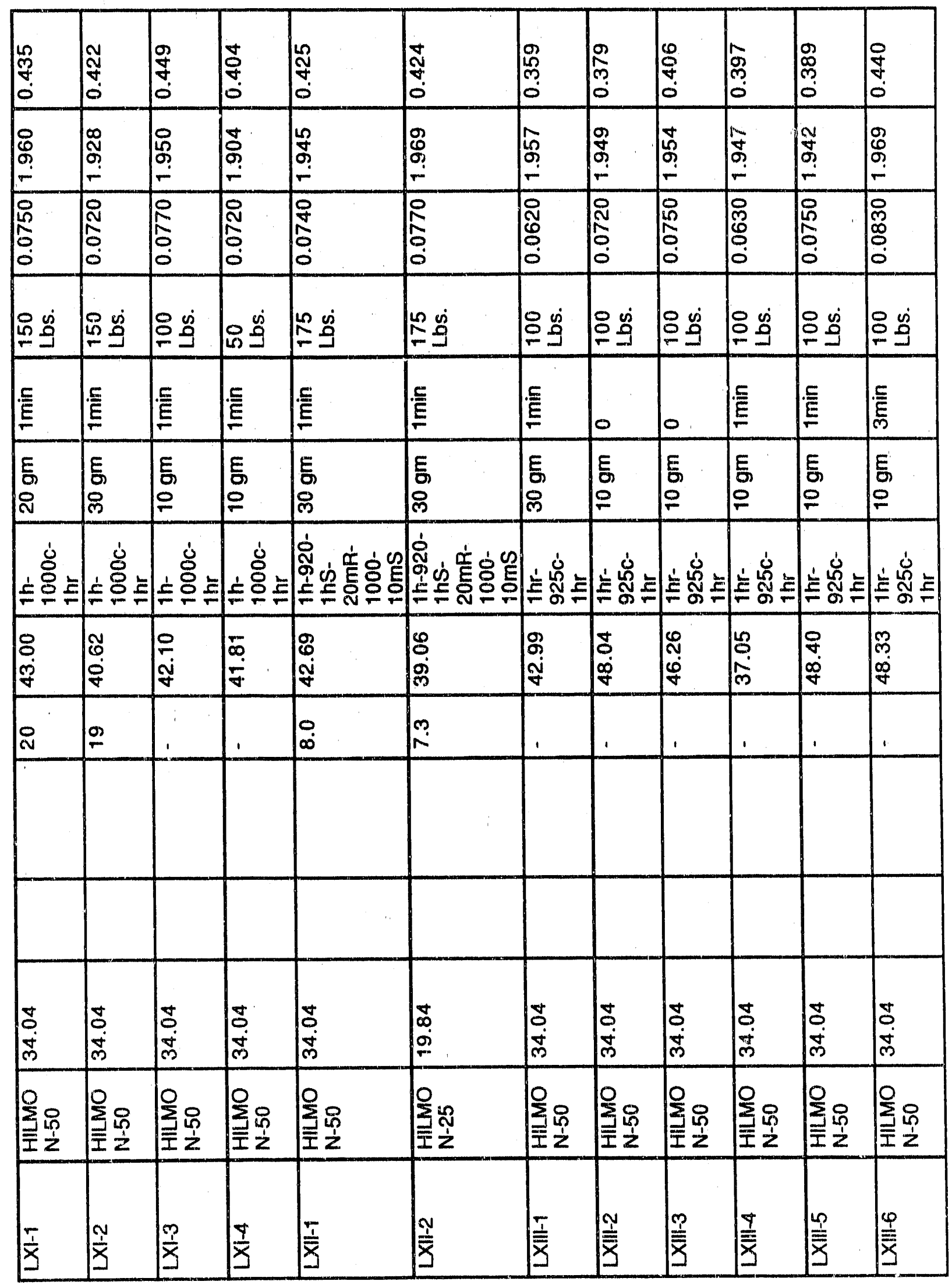




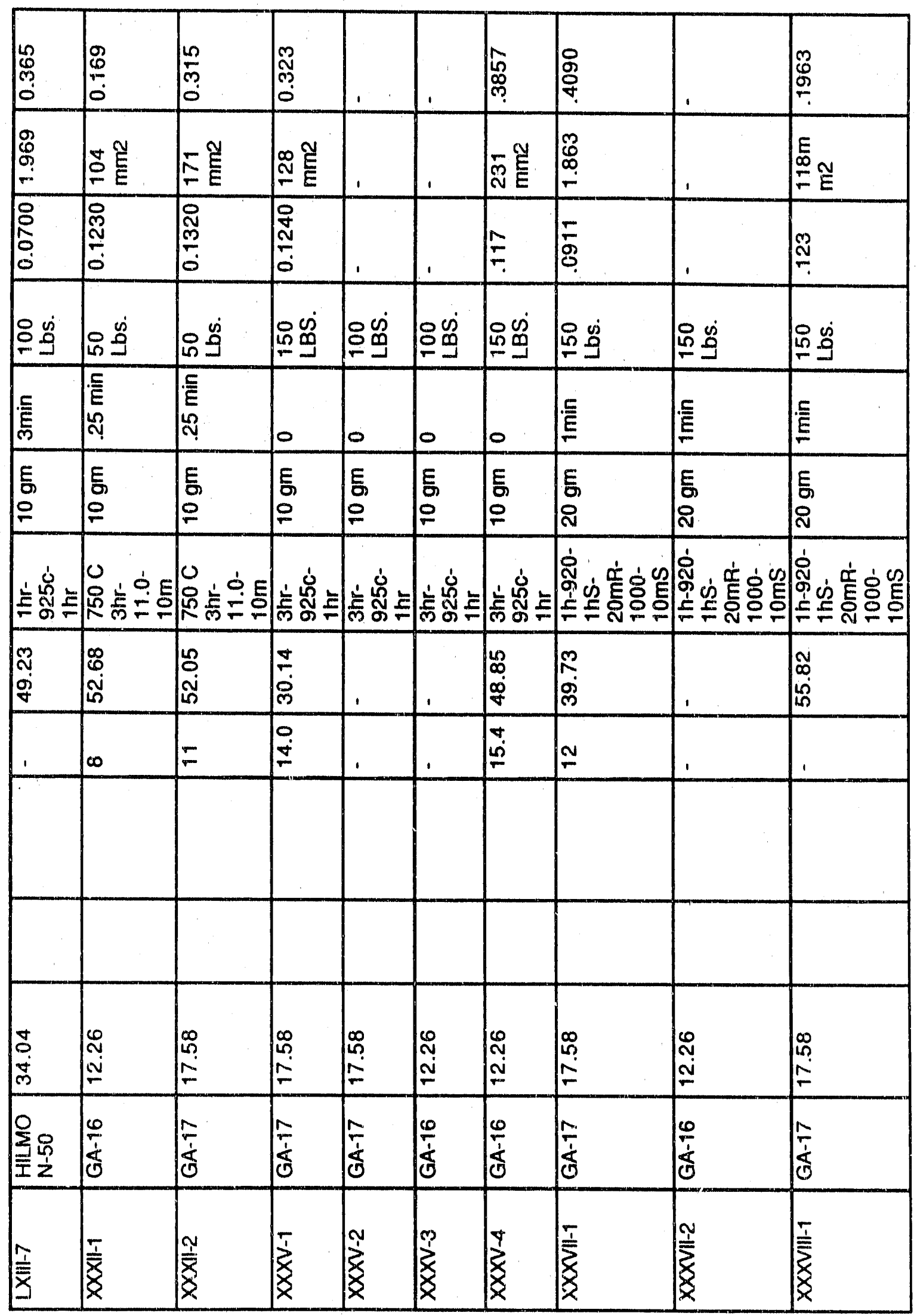




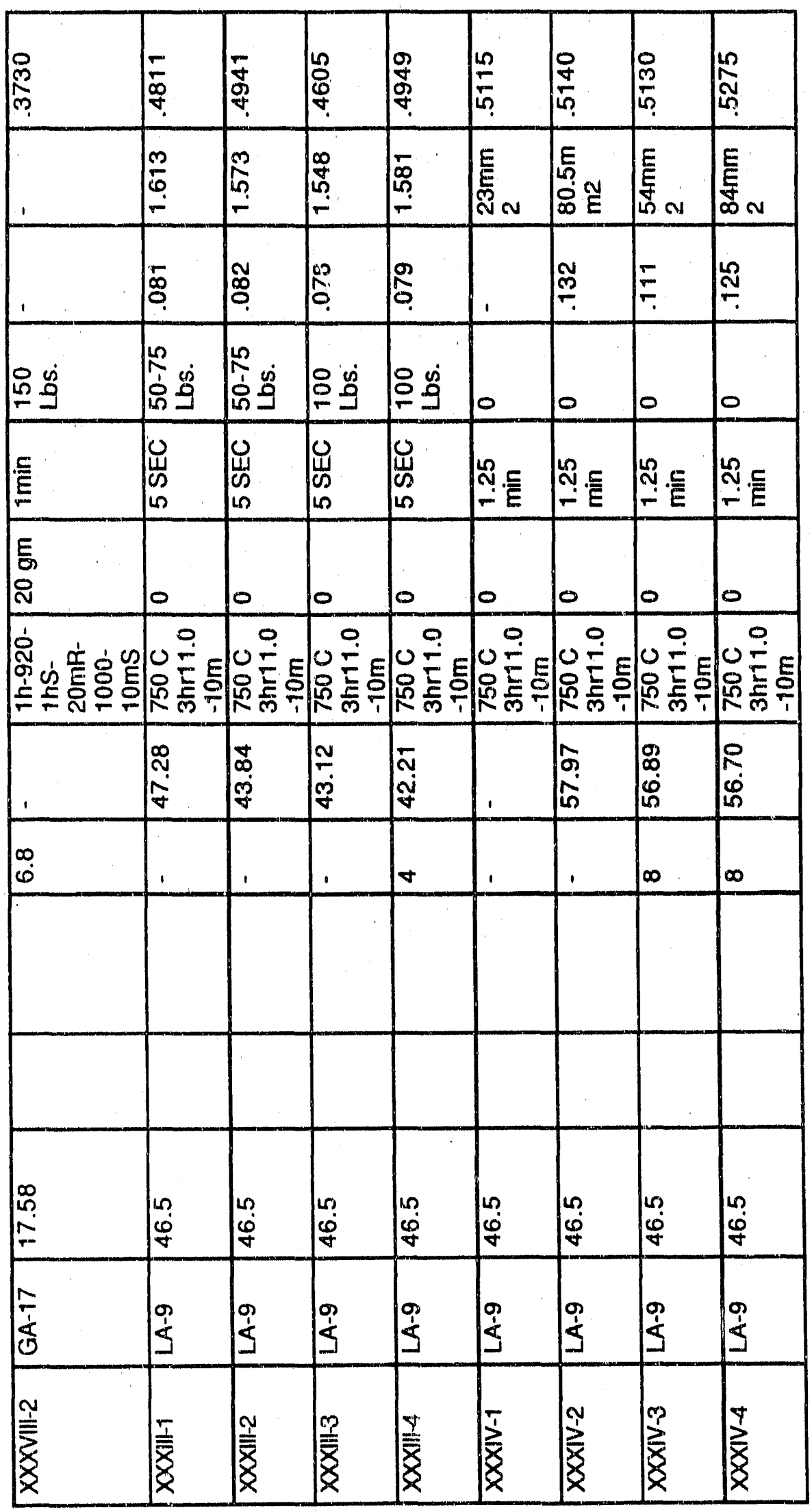




\begin{tabular}{|c|c|c|c|c|c|c|c|c|c|c|c|}
\hline 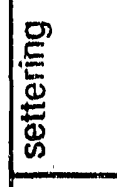 & & & & & & & & & & & \\
\hline 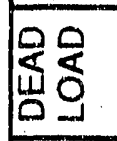 & 营。 & 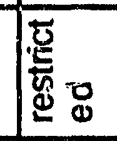 & 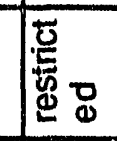 & 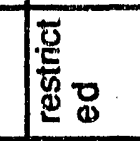 & 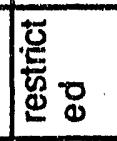 & 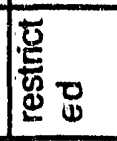 & 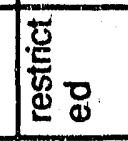 & 辣: & 营。 & 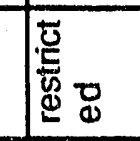 & 愿。 \\
\hline \begin{tabular}{|l|l} 
\\
\end{tabular} & $\mid$ & $\int_{0}^{\infty}$ & $=5$ & 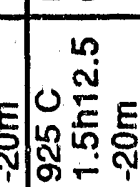 & م & ר్n & 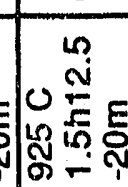 & 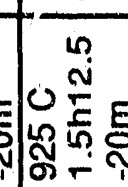 & 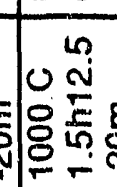 & 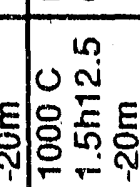 & 实 \\
\hline 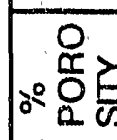 & & 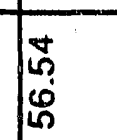 & 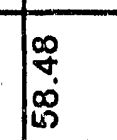 & 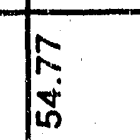 & 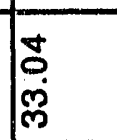 & 总 & 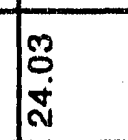 & 刕 & 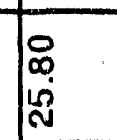 & 豙: & 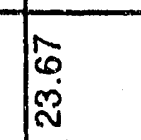 \\
\hline 蓆 & $\begin{array}{l}\infty \\
\frac{\infty}{10} \\
10 \\
0\end{array}$ & 䁬 & 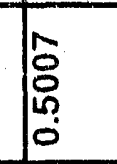 & $\begin{array}{l} \\
\\
0 \\
0 \\
0 \\
0\end{array}$ & 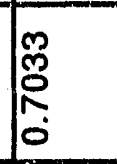 & 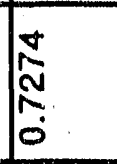 & 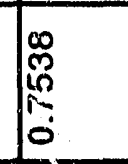 & 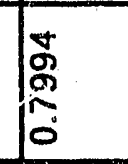 & 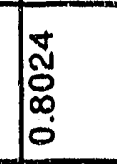 & $\mid \begin{array}{l}\infty \\
0 \\
0 \\
0 \\
0\end{array}$ & {$\left[\begin{array}{l}\bar{\infty} \\
\infty \\
\infty \\
0 \\
0\end{array}\right.$} \\
\hline 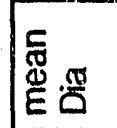 & - & 萬 & : & 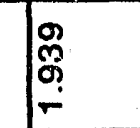 & . & 然 & 然 & 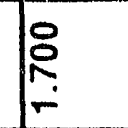 & 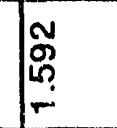 & 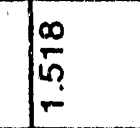 & 店 \\
\hline 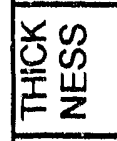 & $\begin{array}{l} \\
0 \\
0 \\
0 \\
0\end{array}$ & $\begin{array}{l}\infty \\
0 \\
0 \\
0 \\
0\end{array}$ & $\begin{array}{l}1 \\
0 \\
0 \\
0\end{array}$ & $\begin{array}{l} \\
\\
0 \\
0\end{array}$ & 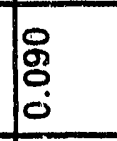 & \begin{tabular}{|l|} 
\\
$\vdots$ \\
0 \\
0 \\
0
\end{tabular} & \begin{tabular}{|l} 
\\
0 \\
0 \\
0 \\
\end{tabular} & $\begin{array}{l}\tilde{\tilde{z}} \\
0 \\
0 \\
0\end{array}$ & $\begin{array}{l} \\
0 \\
0 \\
0 \\
0\end{array}$ & 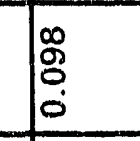 & $\begin{array}{l}0 \\
0 \\
0 \\
0\end{array}$ \\
\hline 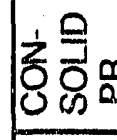 & 盗骂 & 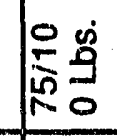 & 量骂 & 最总 & 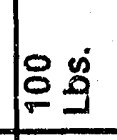 & 实 & 号 & 总皇 & Ko & L. & Ko \\
\hline 峛崖 & 稁 & $\mid \underline{\underline{\underline{E}}}$ & $\mid \underline{\underline{E}}$ & $\mid \begin{array}{c}\mathbf{c} \\
\underline{\underline{E}}\end{array}$ & $\mid \begin{array}{l}\underline{\underline{E}} \\
\underline{\underline{\underline{E}}}\end{array}$ & $\mid \underline{\underline{E}}$ & $\mid \underline{\underline{\underline{E}}}$ & 稁 & 豎 & 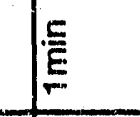 & 嗀 \\
\hline$\frac{\infty}{2}$ & & & & & & & & & & & \\
\hline $\begin{array}{l}3 \\
0 \\
0 \\
0\end{array}$ & $\begin{array}{l}\overrightarrow{0} \\
\dot{p} \\
\tilde{e}\end{array}$ & \begin{tabular}{|l}
$\overline{0}$ \\
$\dot{p}$ \\
$\dot{m}$
\end{tabular} & \begin{tabular}{|l}
$\overline{0}$ \\
$\dot{p}$ \\
$\dot{m}$
\end{tabular} & \begin{tabular}{|l}
$\overline{0}$ \\
$\dot{p}$ \\
\end{tabular} & \begin{tabular}{|l}
$\bar{e}$ \\
$\tilde{D}$ \\
\end{tabular} & \begin{tabular}{|l} 
\\
0 \\
$\dot{m}$ \\
\end{tabular} & \begin{tabular}{|l}
$\overline{0}$ \\
$\dot{p}$ \\
$j$ \\
\end{tabular} & \begin{tabular}{|l}
$\tilde{b}$ \\
$\dot{j}$ \\
\end{tabular} & $\begin{array}{l}\overline{0} \\
\dot{j} \\
\end{array}$ & 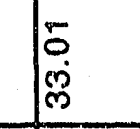 & \begin{tabular}{|l}
$\bar{b}$ \\
$\dot{j}$ \\
\end{tabular} \\
\hline$\sum_{0}^{\infty}$ & 亲 & 变 & 杰 & 密 & 变 & 吕 & 杰 & 疍 & 变 & 离 & 亦 \\
\hline \begin{tabular}{|l|l|} 
\\
\\
\end{tabular} & $\begin{array}{l} \\
9 \\
0 \\
0 \\
\end{array}$ & $\begin{array}{l} \\
8 \\
8 \\
0\end{array}$ & $\begin{array}{l} \\
9 \\
0 \\
0 \\
\end{array}$ & 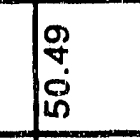 & $\begin{array}{l} \\
8 \\
0.0 \\
\end{array}$ & \begin{tabular}{|l} 
\\
9 \\
8 \\
0 \\
\end{tabular} & \begin{tabular}{|l} 
\\
\\
0 \\
0 \\
\end{tabular} & $\begin{array}{l} \\
8 \\
0.0 \\
0\end{array}$ & $\begin{array}{l} \\
9 \\
0 \\
0 \\
0\end{array}$ & \begin{tabular}{|l} 
\\
\\
0 \\
0 \\
0
\end{tabular} & $\begin{array}{l}\text { o. } \\
8 \\
0.0 \\
\end{array}$ \\
\hline 产䍃 & 站 & $\hat{E}$ & $E$ & i & $\hat{i}$ & 谙 & 䨔 & $\frac{F}{\dot{I}}$ & $\underline{i}$ & 童 & 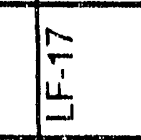 \\
\hline 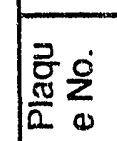 & $\begin{array}{l} \\
\\
\end{array}$ & ריצ & $\frac{x}{3}$ & $\frac{x}{3}$ & 居 & 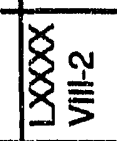 & 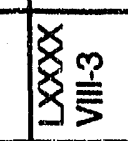 & 条䓂 & $\overline{\bar{I}}$ & $\sqrt{\underline{Y}}$ & 管 \\
\hline
\end{tabular}




\begin{tabular}{|c|c|c|c|c|c|c|c|c|c|c|c|c|}
\hline & & & & & $\ddot{0}$ & $\begin{array}{l}0 \\
0 \\
0\end{array}$ & 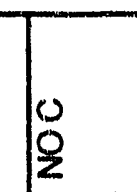 & & & & & 草 \\
\hline & 礉。 & 㕌。 & 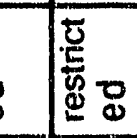 & 薣。 & 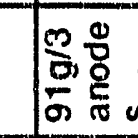 & 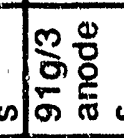 & 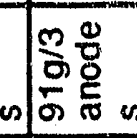 & 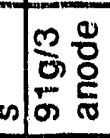 & 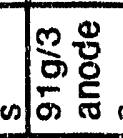 & 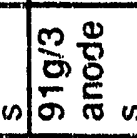 & 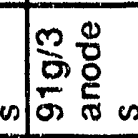 & 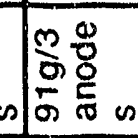 \\
\hline 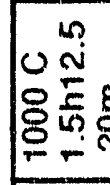 & 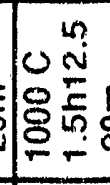 & 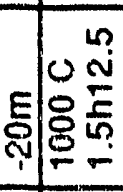 & ํ. & 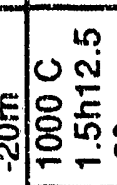 & 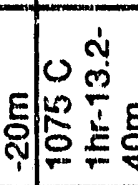 & 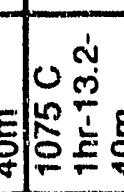 & 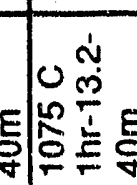 & 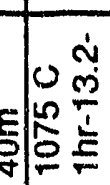 & 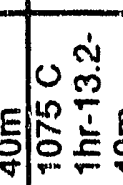 & 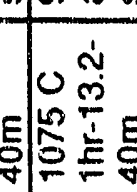 & 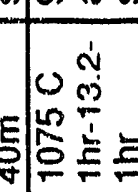 & 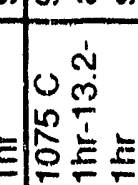 \\
\hline 0 & $\frac{8}{20}$ & $\frac{8}{10}$ & $\frac{8}{10}$ & $\frac{8}{80}$ & 总 & 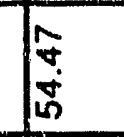 & $\begin{array}{l}8 \\
8 \\
0 \\
0 \\
0\end{array}$ & 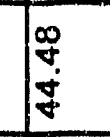 & 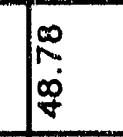 & 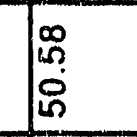 & 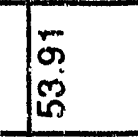 & \begin{tabular}{|l} 
\\
8 \\
0 \\
0 \\
0
\end{tabular} \\
\hline 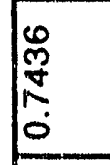 & 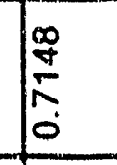 & $\begin{array}{l}1 \\
\vdots \\
0 \\
0\end{array}$ & $\begin{array}{l}0 \\
0 \\
0 \\
0 \\
0 \\
0\end{array}$ & 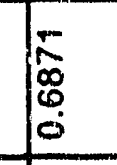 & 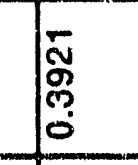 & $\begin{array}{l}5 \\
0 \\
0\end{array}$ & $\begin{array}{l} \\
\\
\\
0\end{array}$ & 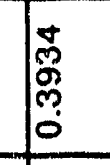 & $\begin{array}{l} \\
0 \\
0 \\
0\end{array}$ & 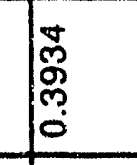 & 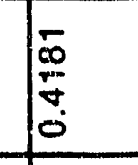 & $\begin{array}{l}0 \\
0 \\
0 \\
0\end{array}$ \\
\hline 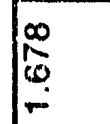 & 隹 & 孚 & 萬 & 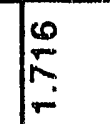 & 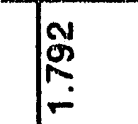 & 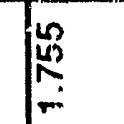 & בְ̃ & 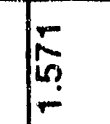 & 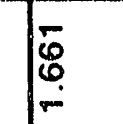 & 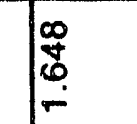 & 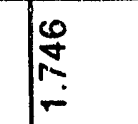 & 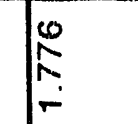 \\
\hline & $\begin{array}{l}\overrightarrow{1} \\
0 \\
0 \\
0\end{array}$ & $\begin{array}{l}0 \\
0 \\
0 \\
0 \\
0\end{array}$ & 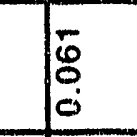 & 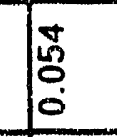 & $\mid \begin{array}{l}8 \\
0 \\
0 \\
0\end{array}$ & 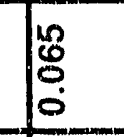 & $\begin{array}{l}0 \\
0 \\
0 \\
0 \\
0\end{array}$ & \begin{tabular}{|l}
0 \\
0 \\
0 \\
0 \\
0
\end{tabular} & 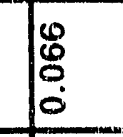 & $\begin{array}{l}8 \\
0 \\
0 \\
0\end{array}$ & $\begin{array}{l}0 \\
0 \\
0 \\
0\end{array}$ & $\begin{array}{l}0 \\
0 \\
0 \\
0\end{array}$ \\
\hline 曋 & 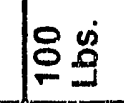 & 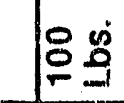 & 疍 & 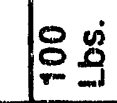 & $\because \stackrel{8}{3}$ & 89 & 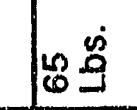 & $\oiiint \stackrel{6}{3}$ & 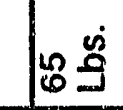 & ذِ & $16 \underbrace{\circ}$ & $\% \stackrel{8}{8}$ \\
\hline & $\mid$ & $\mid \begin{array}{c}\bar{C} \\
\underline{E}\end{array}$ & $\mid \begin{array}{c}\text { E } \\
\underline{E}\end{array}$ & 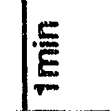 & 宦 & $\mid \underline{\underline{E}}$ & $\mid \begin{array}{c}\underline{E} \\
\underline{E}\end{array}$ & $\mid$ & 点 & 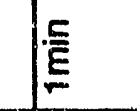 & 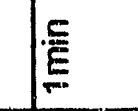 & 毫 \\
\hline & & & & & & & & & & & מـ & :ं० \\
\hline 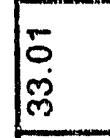 & 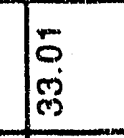 & \begin{tabular}{|l}
$\overline{0}$ \\
$\bar{p}$ \\
\end{tabular} & 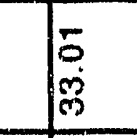 & 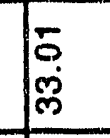 & 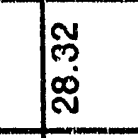 & 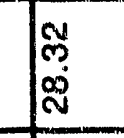 & 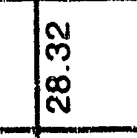 & 第 & 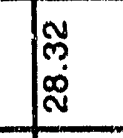 & 芯 & 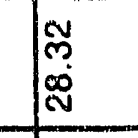 & 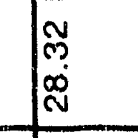 \\
\hline & 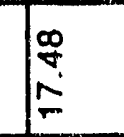 & 票 & 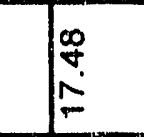 & 竞 & \begin{tabular}{|l}
$\vec{j}$ \\
$\dot{p}$ \\
$\dot{p}$
\end{tabular} & 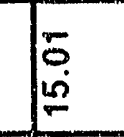 & $\begin{array}{r}\vec{b} \\
\dot{p} \\
\end{array}$ & \begin{tabular}{|l}
$\overline{\dot{b}}$ \\
$\underline{\dot{\varphi}}$
\end{tabular} & $\begin{array}{l}\dot{b} \\
\dot{\rho} \\
\dot{\rho}\end{array}$ & $\begin{array}{l}\vec{b} \\
\dot{p} \\
\dot{p}\end{array}$ & 芦 & 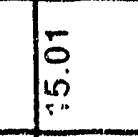 \\
\hline & \begin{tabular}{|l} 
\\
8 \\
0 \\
0 \\
0
\end{tabular} & \begin{tabular}{|l} 
\\
9 \\
0 \\
0 \\
\end{tabular} & $\begin{array}{l} \\
9 \\
0 \\
0 \\
\end{array}$ & \begin{tabular}{|l} 
\\
8 \\
8 \\
6 \\
\end{tabular} & 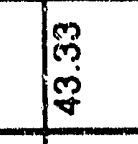 & 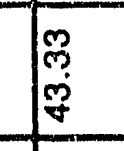 & 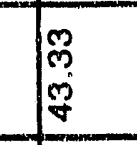 & 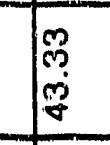 & 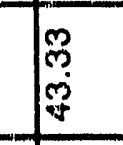 & 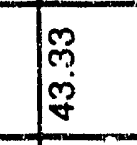 & 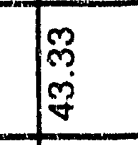 & 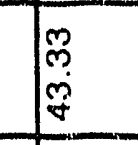 \\
\hline & $E$ & $\overline{4}$ & $E$ & E & 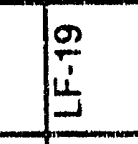 & $\begin{array}{l} \\
\end{array}$ & $\begin{array}{l} \\
\\
\end{array}$ & $\frac{9}{4}$ & $\frac{O}{2}$ & $\frac{9}{\dot{s}}$ & 焉 & $\frac{9}{5}$ \\
\hline & 隹 & $\sqrt{\tilde{B}}$ & 列 & 语 & $\bar{z}$ & 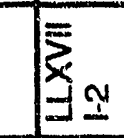 & $\underline{\chi_{x}}$ & ז & $\overline{\bar{Z}_{N}}$ & 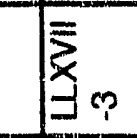 & $\bar{E}$ & 筫 \\
\hline
\end{tabular}




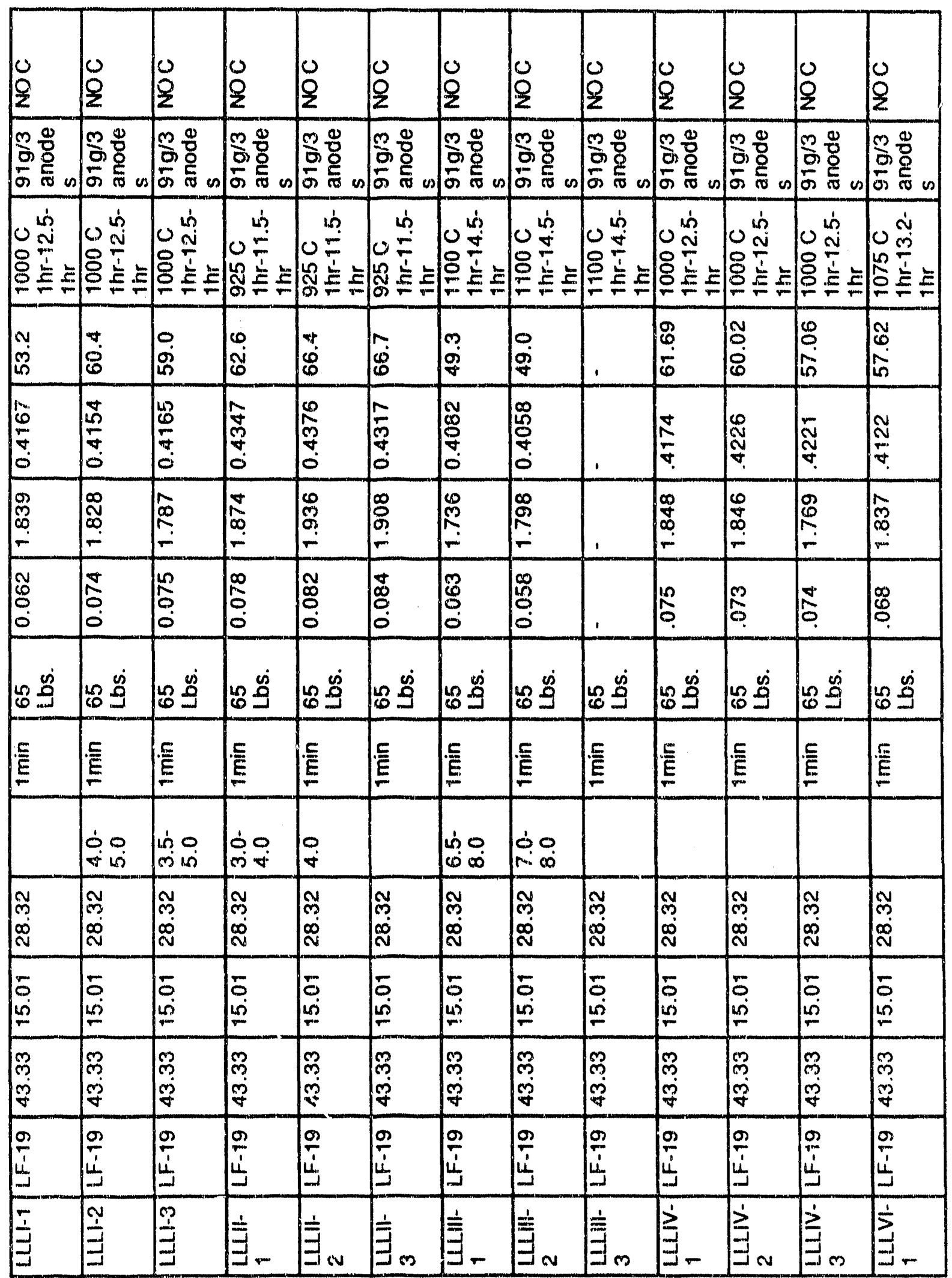




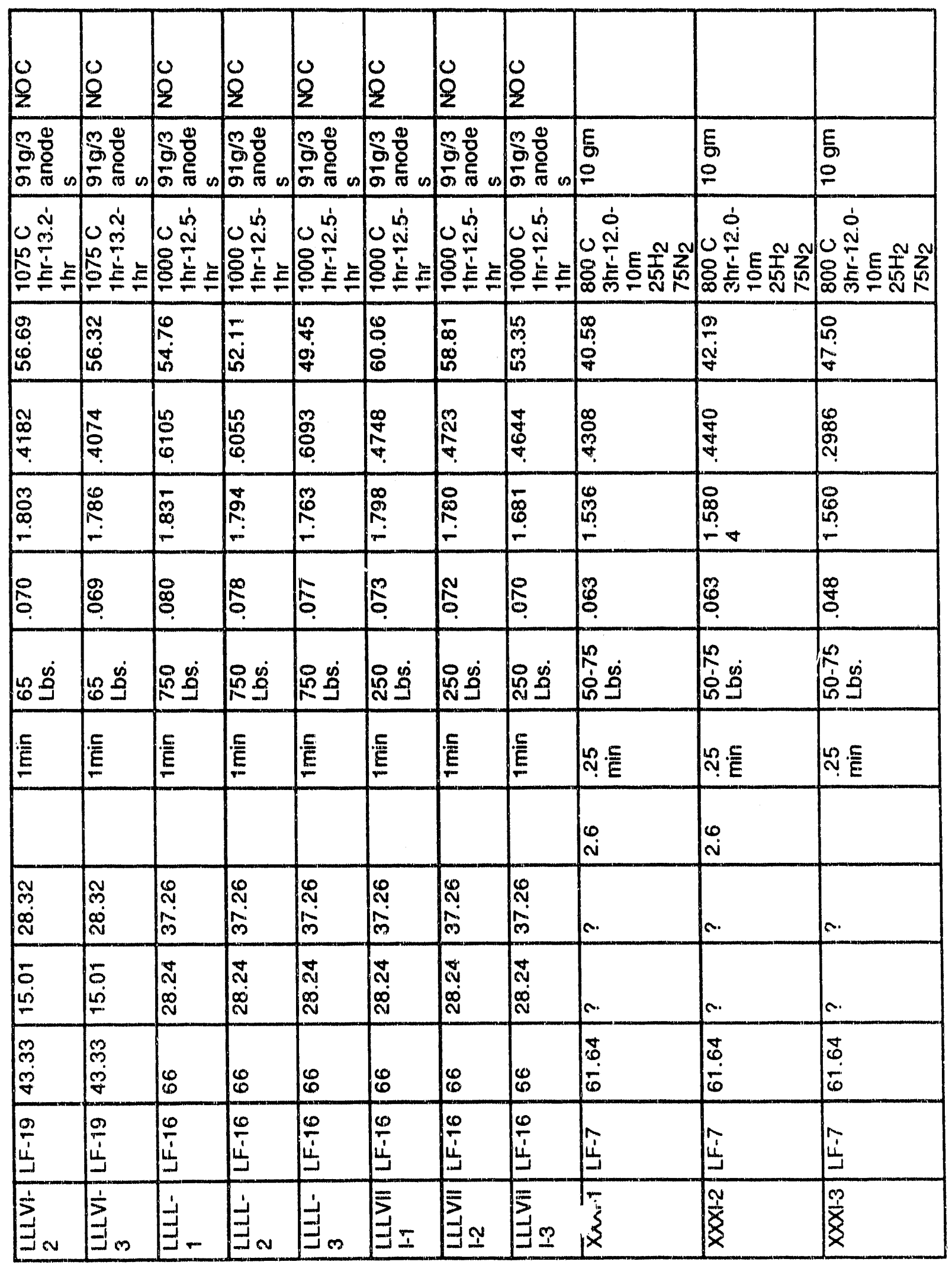




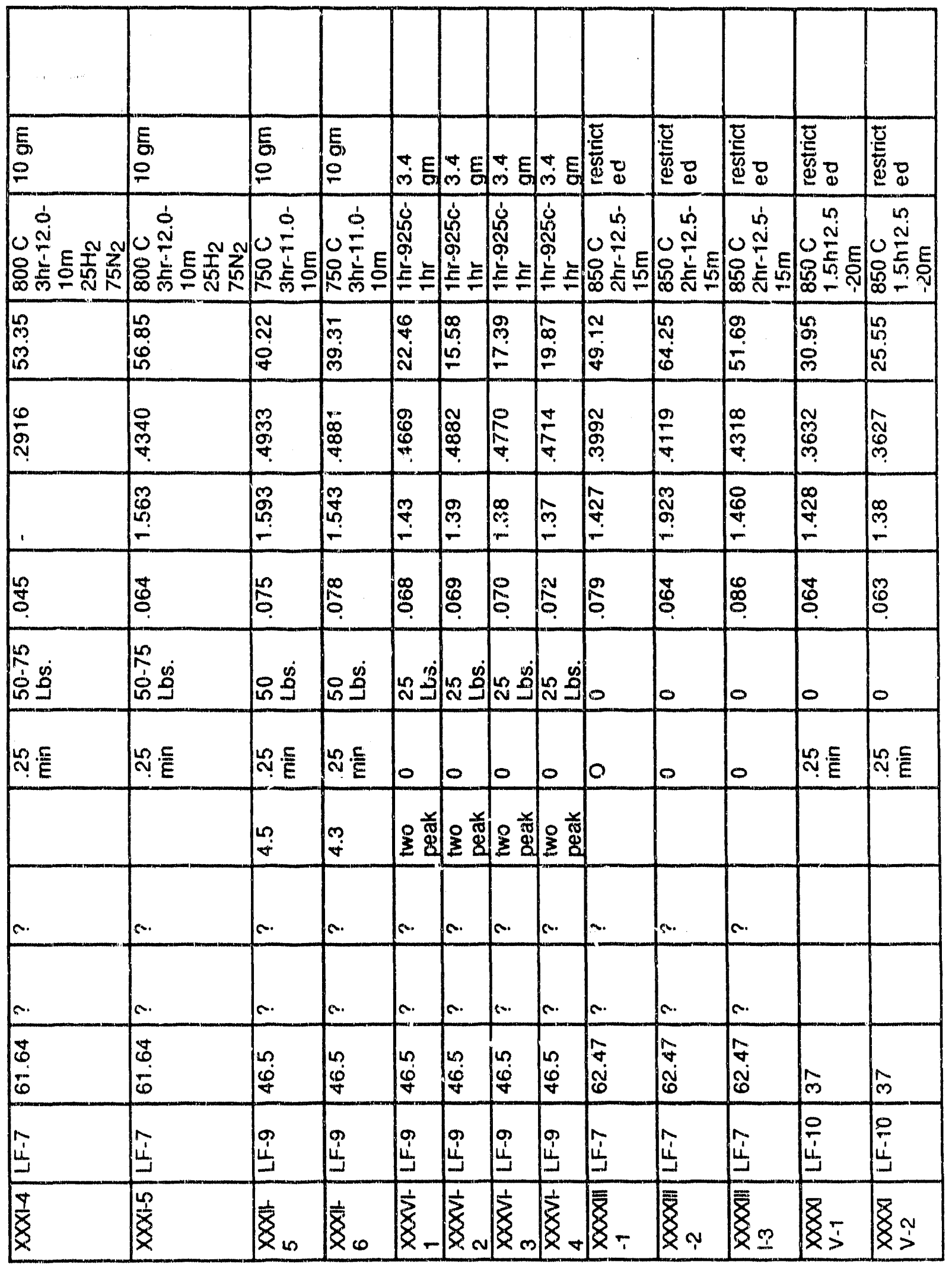




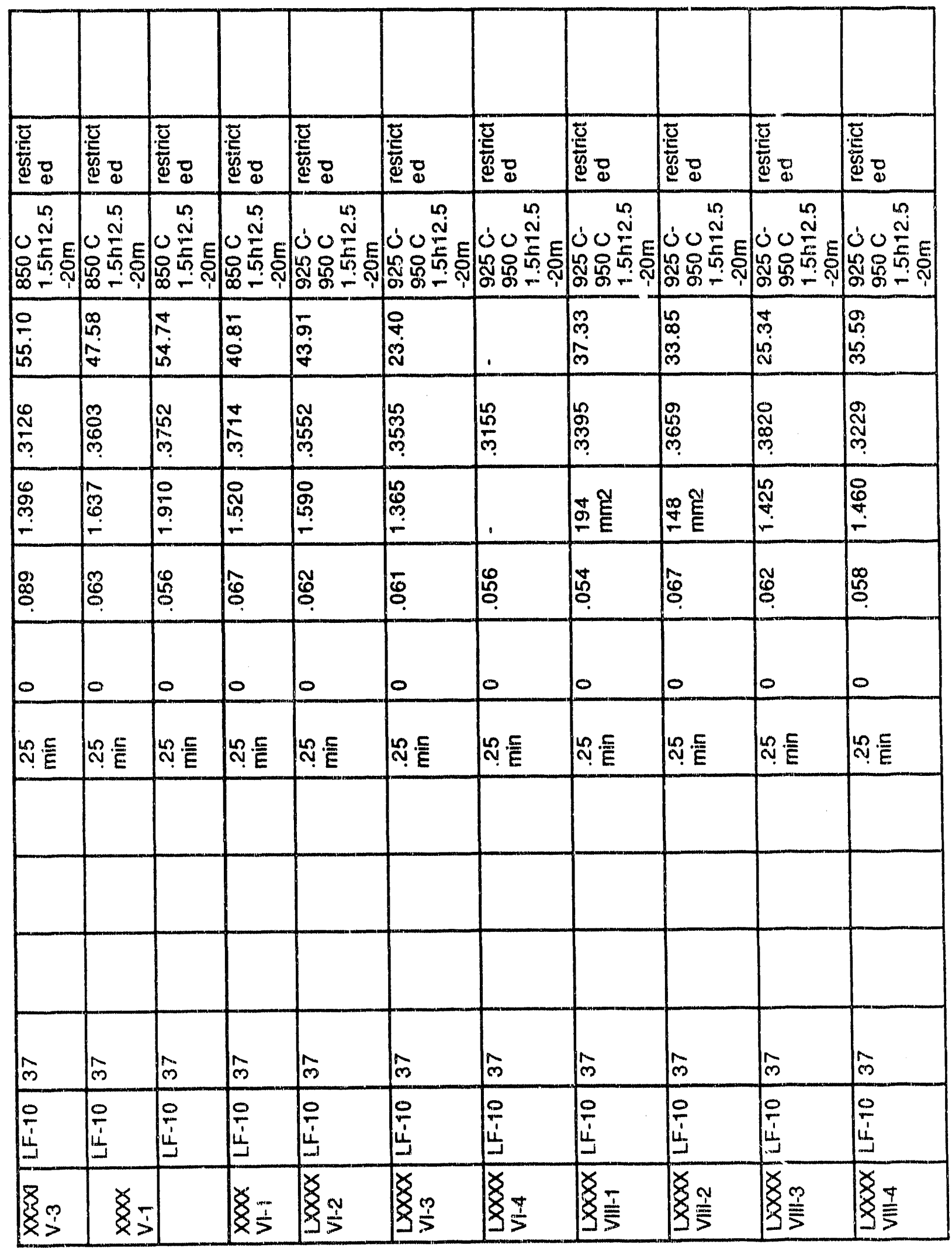




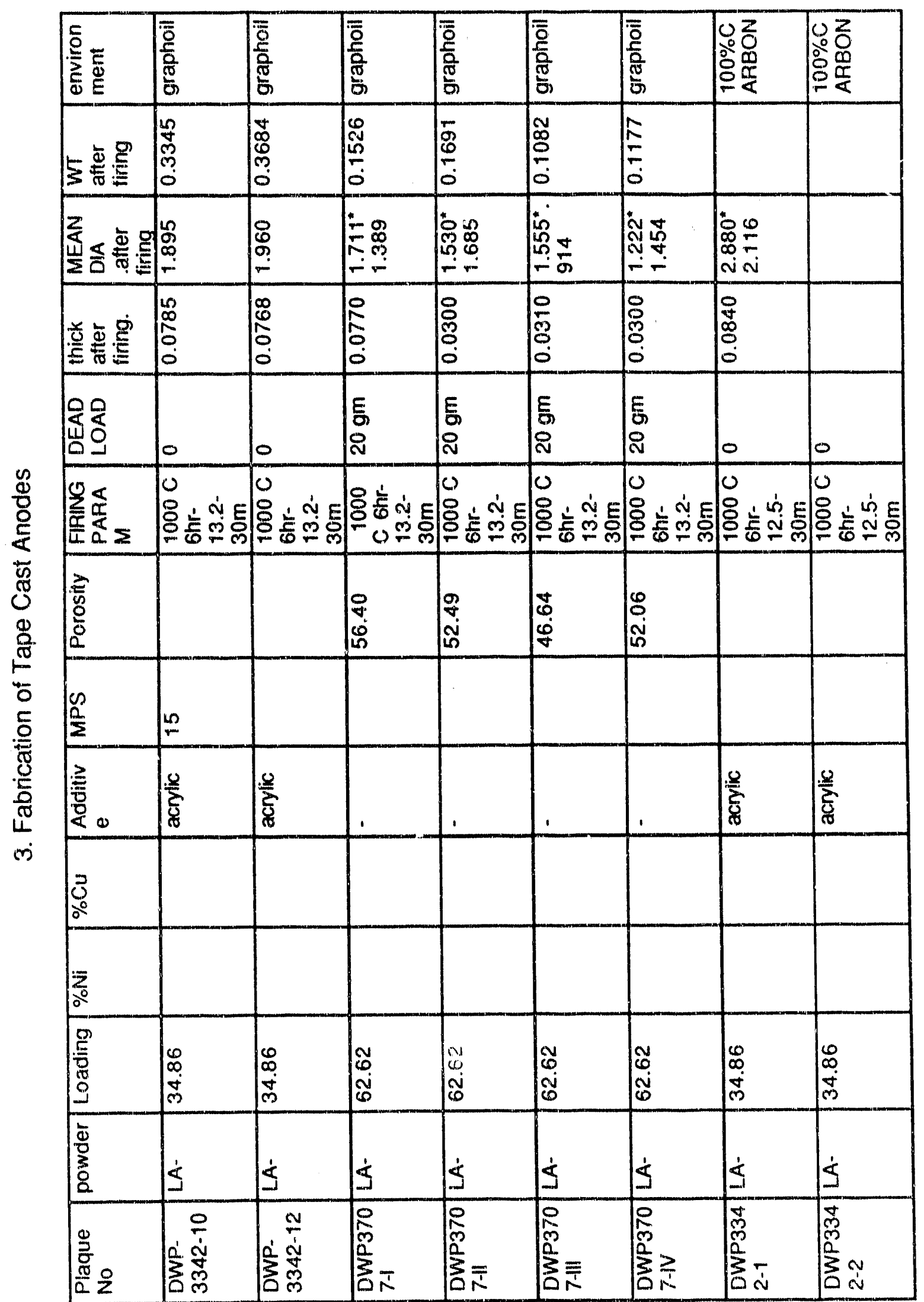




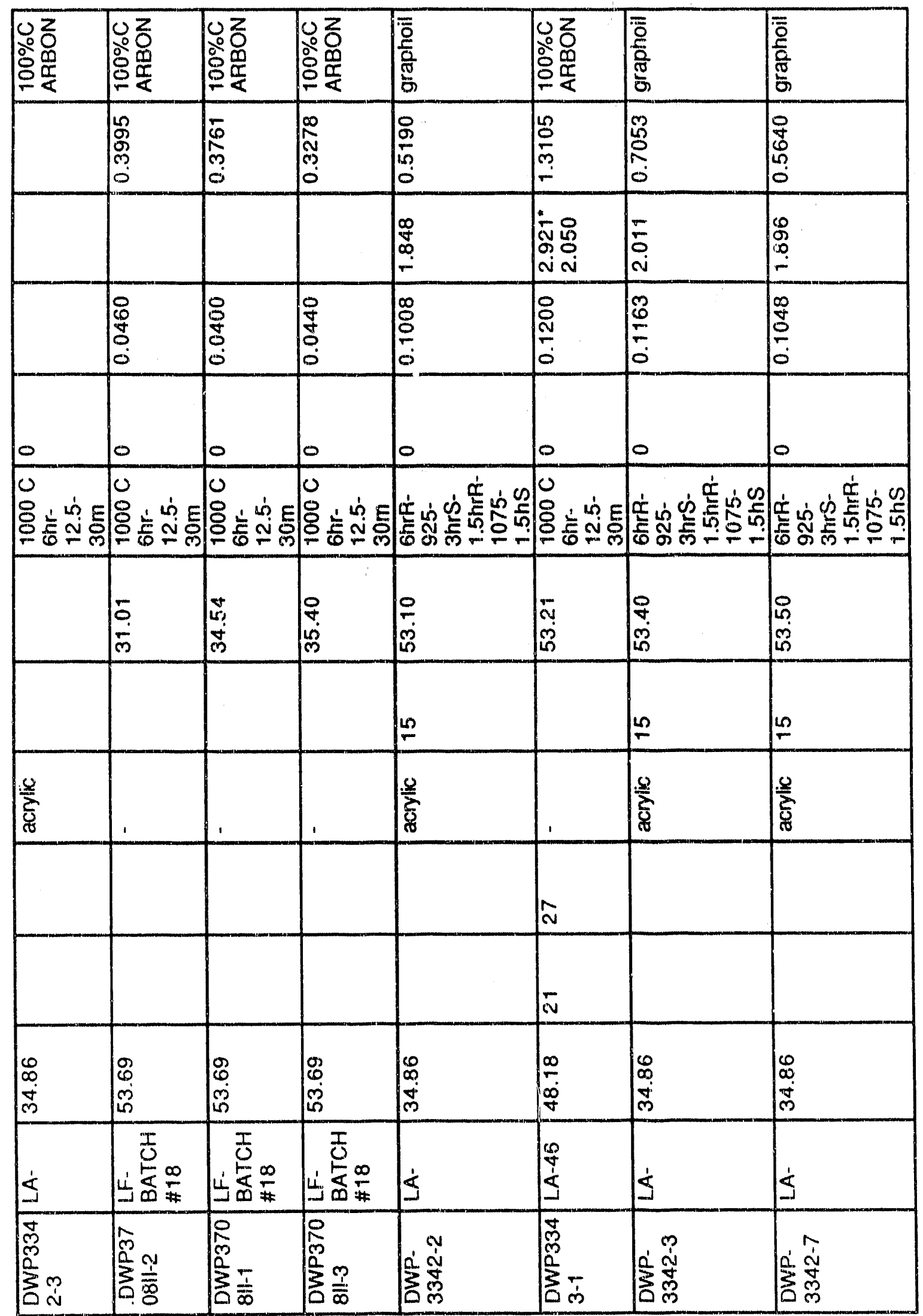




\begin{tabular}{|c|c|c|c|c|c|c|}
\hline 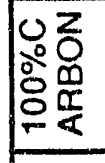 & 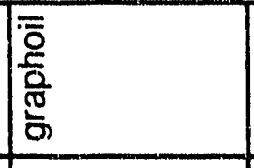 & 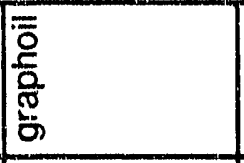 & 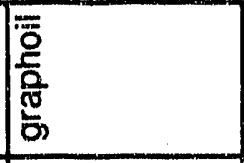 & 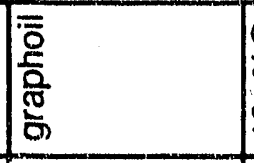 & 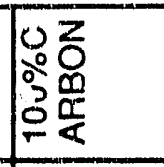 & 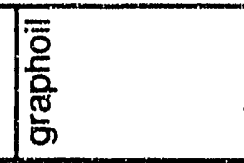 \\
\hline Nָ & \begin{tabular}{|l}
1 \\
$\infty$ \\
$\tilde{~}$ \\
0 \\
0 \\
0 \\
\end{tabular} & $\begin{array}{l}1 \\
0 \\
0 \\
0 \\
0 \\
0\end{array}$ & \begin{tabular}{|l}
5 \\
$\tilde{N}$ \\
0 \\
0 \\
0 \\
0
\end{tabular} & $\begin{array}{l}n \\
\infty \\
\infty \\
0 \\
0 \\
0 \\
n\end{array}$ & 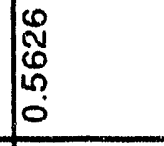 & $\mid \begin{array}{l}\infty \\
0 \\
0 \\
0 \\
0 \\
0 \\
0\end{array}$ \\
\hline 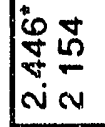 & $\mid \begin{array}{l}\infty \\
0 \\
0 \\
\text { in }\end{array}$ & 童 & 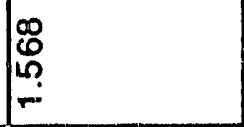 & 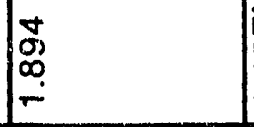 & 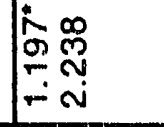 & 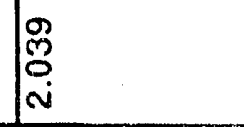 \\
\hline | & $\mid \begin{array}{l}0 \\
0 \\
0 \\
0 \\
0\end{array}$ & 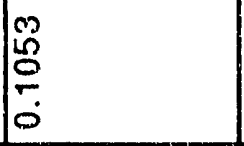 & 吕 & $\begin{array}{l}0 \\
0 \\
0 \\
0 \\
0 \\
0\end{array}$ & $\begin{array}{l}\stackrel{8}{0} \\
\stackrel{2}{0} \\
0 \\
\end{array}$ & $\frac{8}{8}$ \\
\hline 0 & 0 & 0 & 0 & 0 & 0 & 0 \\
\hline $\begin{array}{l}0 \\
0 \\
0 \\
0\end{array}$ & 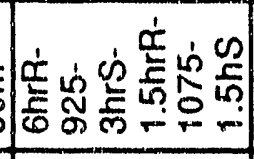 & 离 & 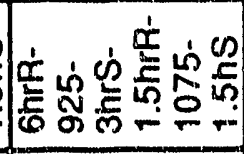 & 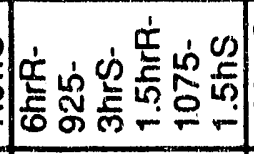 & 足 & 它 \\
\hline 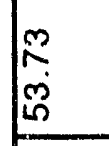 & \begin{tabular}{|l}
0 \\
0 \\
\\
\end{tabular} & $\begin{array}{l} \\
\vdots \\
\dot{0} \\
\dot{5} \\
\end{array}$ & $\mid$ & $\begin{array}{l}0 \\
0 \\
0 \\
\vdots \\
\end{array}$ & \begin{tabular}{|l}
$\overline{5}$ \\
0 \\
0
\end{tabular} & 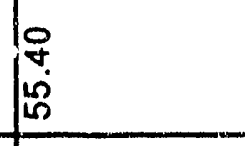 \\
\hline & $\stackrel{n}{\square}$ & 10 & 10 & & & \\
\hline . & 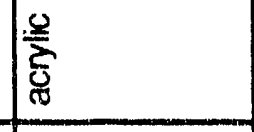 & 告 & $\mid \frac{2}{\bar{z}}$ & 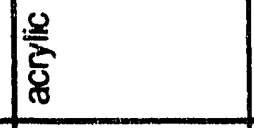 & & \begin{tabular}{|l}
$\frac{2}{2}$ \\
\end{tabular} \\
\hline$\hat{N}$ & & & & & in & \\
\hline $\bar{N}$ & & & & & $\bar{n}$ & \\
\hline $\mid \begin{array}{l}\infty \\
\infty \\
\infty \\
\infty \\
\vdots \\
\end{array}$ & $\begin{array}{l}\infty \\
\infty \\
0 \\
\dot{m}\end{array}$ & $\mid \begin{array}{l}0 \\
0 \\
0 \\
\dot{m} \\
\end{array}$ & $\begin{array}{l}\infty \\
0 \\
0 \\
\dot{m} \\
\end{array}$ & $\mid \begin{array}{l}\infty \\
\infty \\
\infty \\
\tilde{m}\end{array}$ & $\frac{\infty}{\infty}$ & $\mid \begin{array}{l}0 \\
0 \\
\dot{m} \\
\dot{m}\end{array}$ \\
\hline $\mid \begin{array}{l}0 \\
\vdots \\
\vdots \\
\vdots \\
\vdots \\
\end{array}$ & Is & $\$$ & $\$$ & $\$$ & 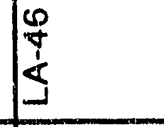 & $\$$ \\
\hline 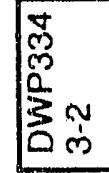 & 望 & 告总 & 势 & 竞离 & 黛 & 帘芦 \\
\hline
\end{tabular}




\begin{tabular}{|c|c|c|c|c|c|c|c|c|c|}
\hline \begin{tabular}{|l|}
$\overline{\bar{z}}$ \\
产 \\
惫
\end{tabular} & 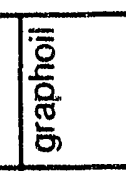 & 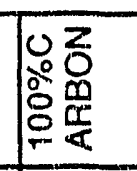 & 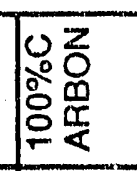 & 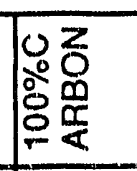 & 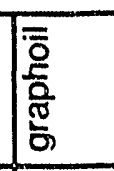 & 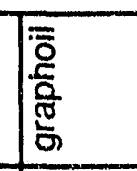 & | & 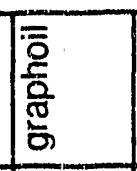 & 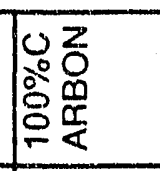 \\
\hline 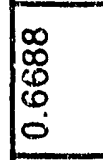 & 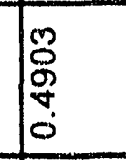 & 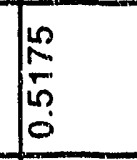 & 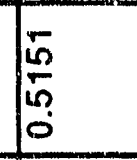 & 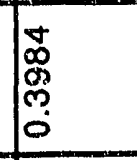 & 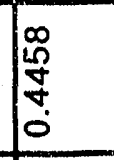 & 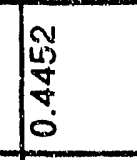 & 离 & 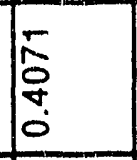 & | \\
\hline 㐫 & \begin{tabular}{|l} 
\\
ò \\
\\
\end{tabular} & 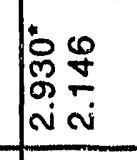 & 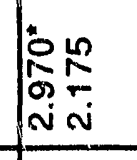 & 隹: & 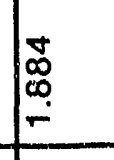 & 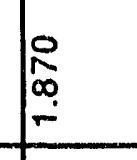 & 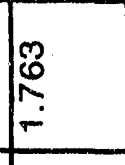 & 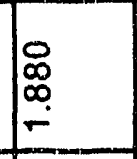 & 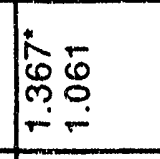 \\
\hline $\begin{array}{l} \\
0 \\
0 \\
0 \\
0 \\
0\end{array}$ & $\begin{array}{l}0 \\
0 \\
0 \\
0 \\
0 \\
0 \\
0\end{array}$ & 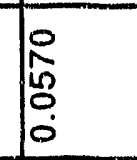 & 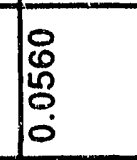 & 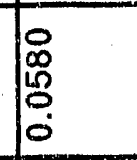 & $\begin{array}{l}0 \\
0 \\
0 \\
0 \\
0 \\
0\end{array}$ & $\begin{array}{l}0 \\
0 \\
0 \\
0 \\
0 \\
0\end{array}$ & $\begin{array}{l}0 \\
0 \\
0 \\
0 \\
0\end{array}$ & 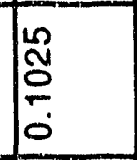 & 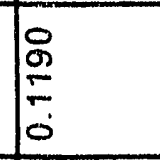 \\
\hline$\infty$ & 0 & 0 & 0 & o & \begin{tabular}{|l}
$E$ \\
$\bar{n}$ \\
\end{tabular} & $\begin{array}{l}\text { E } \\
\\
\end{array}$ & \begin{tabular}{|l}
$E$ \\
$\bar{N}$ \\
\end{tabular} & \begin{tabular}{|l}
$E$ \\
E \\
N
\end{tabular} & 10 \\
\hline & & $\mid \begin{array}{l}0 \\
0 \\
0 \\
0\end{array}$ & $\mid \begin{array}{l}0 \\
0 \\
0 \\
0\end{array}$ & 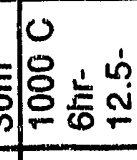 & 递 & 商密 & 窇 & 容点点 & $\begin{array}{l}0 \\
0 \\
0 \\
0\end{array}$ \\
\hline 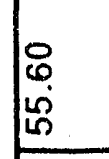 & 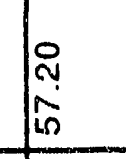 & 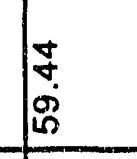 & $\begin{array}{l}8 \\
: \\
\\
\end{array}$ & $\begin{array}{l}\infty \\
\infty \\
0 \\
0 \\
\end{array}$ & 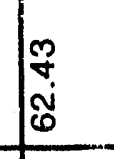 & 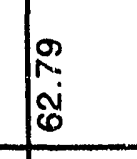 & \begin{tabular}{|l}
$n$ \\
0 \\
0 \\
0 \\
0 \\
0
\end{tabular} & 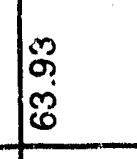 & 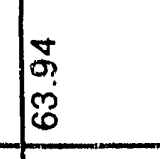 \\
\hline 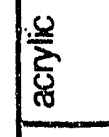 & 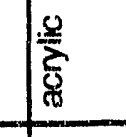 & . & 1. & & 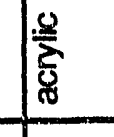 & $\mid \frac{2}{3}$ & 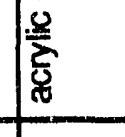 & 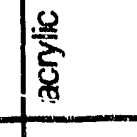 & 耪 \\
\hline $\mid \begin{array}{l}\infty \\
\infty \\
\dot{m} \\
\dot{m} \\
\end{array}$ & $\mid$ & 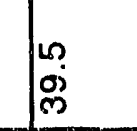 & 恶 & 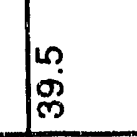 & 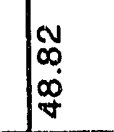 & $\mid$\begin{tabular}{l}
$\infty$ \\
$\infty$ \\
$\infty$ \\
\hdashline
\end{tabular} & 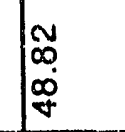 & 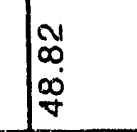 & 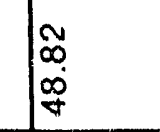 \\
\hline$\dot{\$}$ & 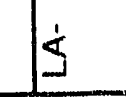 & $\Phi$ & Is & I & $\Phi$ & $ذ$ & 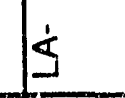 & Is & 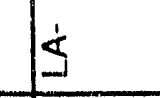 \\
\hline 语 & 总 离 & 产条 & 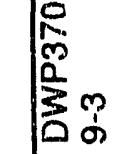 & 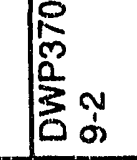 & 商商 & 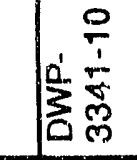 & 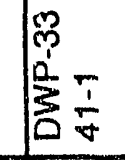 & 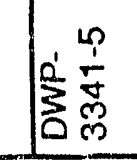 & 售总 \\
\hline
\end{tabular}




\begin{tabular}{|c|c|c|c|c|c|c|}
\hline$\frac{\overline{\bar{c}}}{\frac{\overline{2}}{\frac{\pi}{6}}}$ & $\mid \begin{array}{ll}0 & z \\
20 & 0 \\
0 & 0 \\
0 & \frac{\pi}{\pi} \\
0 & \frac{\pi}{\tau}\end{array}$ & 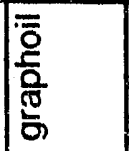 & 票 & $\mid \begin{array}{l}\overline{0} \\
\frac{0}{2} \\
\frac{\pi}{6} \\
\bar{c}\end{array}$ & 言 & 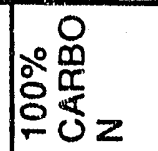 \\
\hline 岕 & $\mid \begin{array}{l}n \\
\infty \\
0 \\
0 \\
0 \\
0\end{array}$ & 隹 & $\mid \begin{array}{l}N \\
2 \\
o \\
n \\
0 \\
0\end{array}$ & 管 & $\mid \begin{array}{l}\tilde{N} \\
\infty \\
0 \\
0 \\
0 \\
0\end{array}$ & 票 \\
\hline $\mid \begin{array}{c}\infty \\
\infty \\
\infty \\
-\end{array}$ & 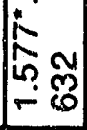 & $\mid \begin{array}{l}0 \\
\infty \\
\infty \\
- \\
\end{array}$ & $\stackrel{n}{2}$ & $\mid \begin{array}{l}0 \\
\infty \\
\infty \\
\infty \\
- \\
-\end{array}$ & 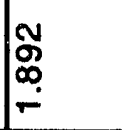 & 蓆 \\
\hline$\frac{m}{0}$ & 兽 & 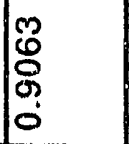 & $\frac{5}{6}$ & 璐 & $\begin{array}{l}0 \\
\hat{0} \\
\frac{0}{0} \\
0\end{array}$ & $\mid \begin{array}{l}0 \\
10 \\
0 \\
0 \\
0\end{array}$ \\
\hline $\begin{array}{l}E \\
\frac{E}{N}\end{array}$ & 0 & $\frac{E}{\bar{a}}$ & $\mid \begin{array}{l}E \\
\bar{n} \\
\bar{N}\end{array}$ & हิ & $\begin{array}{l}E \\
\bar{\delta} \\
\bar{N}\end{array}$ & 10 \\
\hline 站 & $\begin{array}{l}0 \\
0 \\
0 \\
0\end{array}$ & 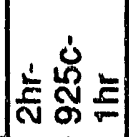 & 悹 & సั่ & ت & $\mid \begin{array}{l}0 \\
0 \\
0\end{array}$ \\
\hline $\begin{array}{l}\mathscr{0} \\
0 \\
\dot{0}\end{array}$ & $\begin{array}{l}\infty \\
0 \\
\dot{0} \\
0\end{array}$ & $\begin{array}{l}\infty \\
m \\
\infty \\
\infty\end{array}$ & $\begin{array}{l}\infty \\
0 \\
18 \\
18\end{array}$ & $\mid \begin{array}{l}8 \\
0 \\
0 \\
0\end{array}$ & $\begin{array}{l}3 \\
6 \\
0 \\
0\end{array}$ & $\mid \begin{array}{l}\infty \\
\infty \\
00 \\
60\end{array}$ \\
\hline 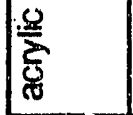 & 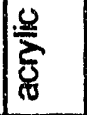 & $\frac{.02}{\sum_{0}^{\circ}}$ & $\frac{52}{\sum_{y=d}^{2}}$ & $\frac{2}{\sum_{\overparen{d}}}$ & : & 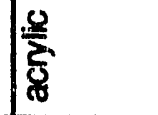 \\
\hline $\mid \begin{array}{l}N \\
\infty \\
\infty \\
0 \\
y\end{array}$ & $\mid \begin{array}{l}\infty \\
\infty \\
\infty \\
\infty \\
\forall\end{array}$ & $\begin{array}{l}\tilde{N} \\
\infty \\
\infty \\
\infty \\
\square\end{array}$ & $\mid \begin{array}{l}N \\
\infty \\
\infty \\
\infty \\
\forall\end{array}$ & $\mid \begin{array}{l}\infty \\
\infty \\
\infty \\
\infty \\
\infty \\
\infty\end{array}$ & $\mid \begin{array}{l}\infty \\
\infty \\
\infty \\
\infty\end{array}$ & $\mid \begin{array}{l}\infty \\
\infty \\
\infty \\
\infty\end{array}$ \\
\hline$\leq$ & $\$$ & 5 & $1 \frac{1}{5}$ & $\$$ & 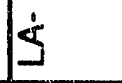 & $1 \dot{S}$ \\
\hline 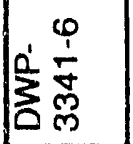 & 告 & $\frac{0}{\frac{1}{2}}$ & 告 & 袋 & 竞 & 产㝘 \\
\hline
\end{tabular}



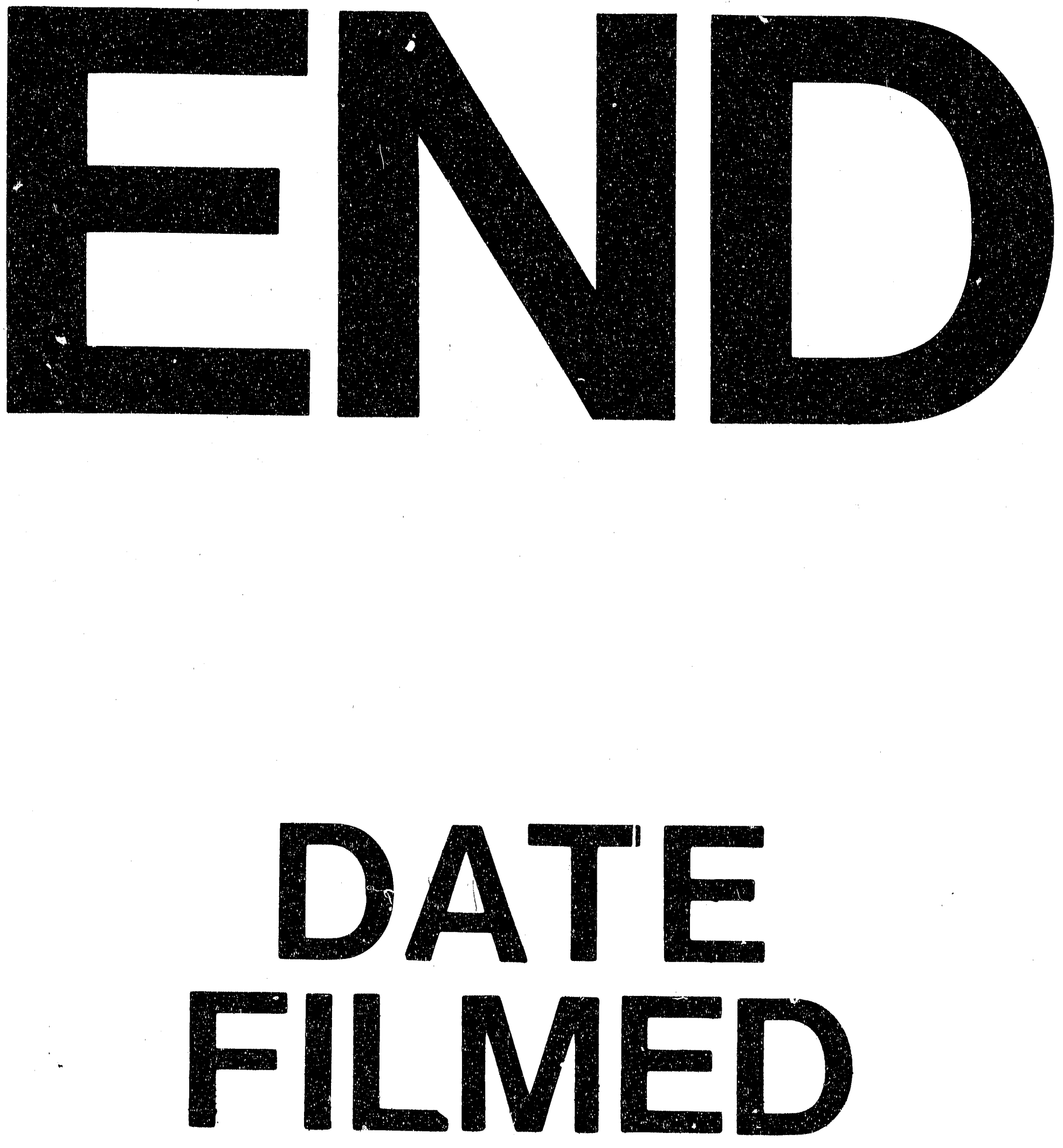

$p$

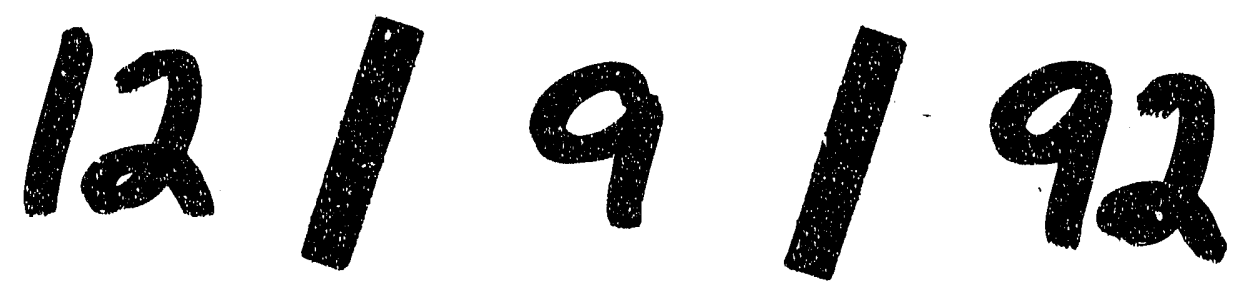


